\title{
Effect of Ice Formation and Streamflow on Salmon Incubation Habitat in the Lower Bradley River, Alaska
}

By Ronald L. Rickman

U.S. GEOLOGICAL SURVEY

Water-Resources Investigations Report 96-4202

Prepared in cooperation with the ALASKA ENERGY AUTHORITY

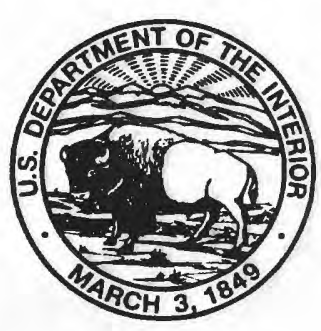




\section{U.S. DEPARTMENT OF THE INTERIOR BRUCE BABBITT, Secretary}

U.S. GEOLOGICAL SURVEY GORDON P. EATON, Director

For additional information write to:

\section{District Chief}

U.S. Geological Survey 4230 University Drive, Suite 201 Anchorage, AK 99508-4664
Copies of this report may be purchased from:

U.S. Geological Survey

Branch of Information Services

Box 25286

Denver, CO 80225-0286 


\section{CONTENTS}

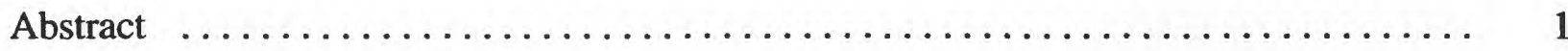

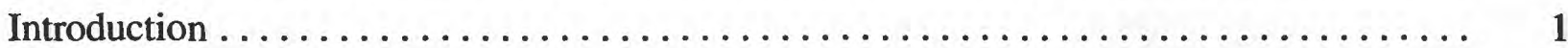

Location of Study Area $\ldots \ldots \ldots \ldots \ldots \ldots \ldots \ldots \ldots \ldots \ldots \ldots \ldots \ldots \ldots \ldots \ldots \ldots, 1$

Bradley Lake Hydroelectric Project $\ldots \ldots \ldots \ldots \ldots \ldots \ldots \ldots \ldots \ldots \ldots \ldots, 1$

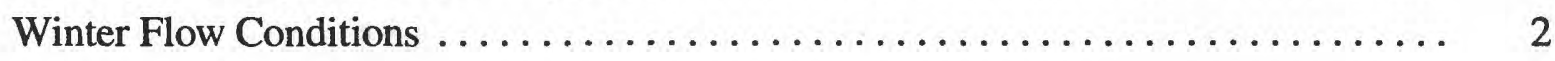

Purpose and Scope. ................................ 3

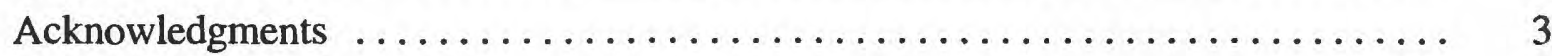

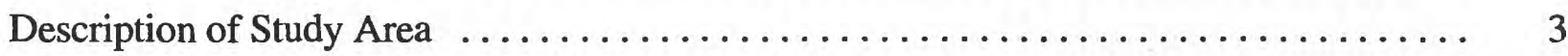

Bear Island $\ldots \ldots \ldots \ldots \ldots \ldots \ldots \ldots \ldots \ldots \ldots \ldots \ldots \ldots \ldots, 4$

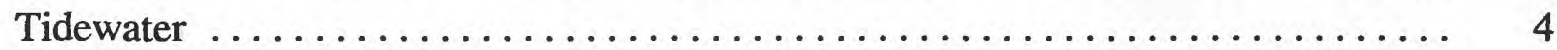

Tree Bar Reach ..................................... 5

Below Fish Camp .................................... 5

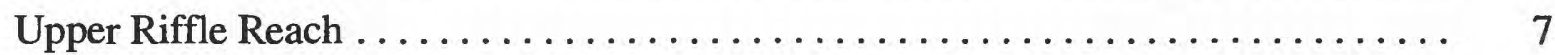

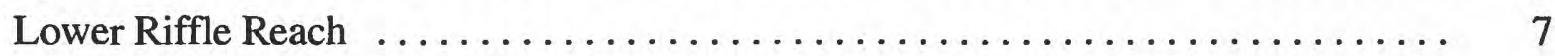

Middle Fork Bradley River Below North Fork Bradley River............. 7

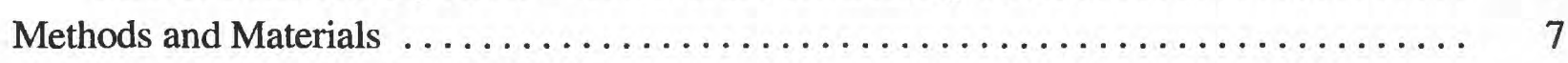

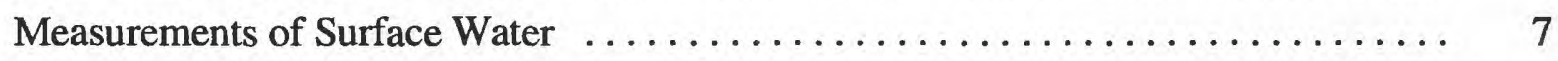

Measurement of Intragravel Water ........................... 8

Observation Methods of Spawning Area Locations and Population Estimates ...... 9

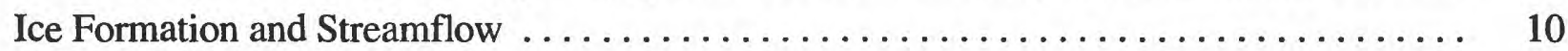

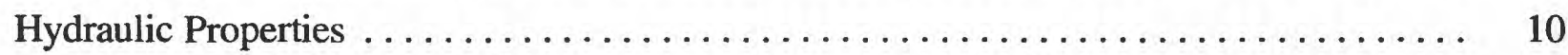

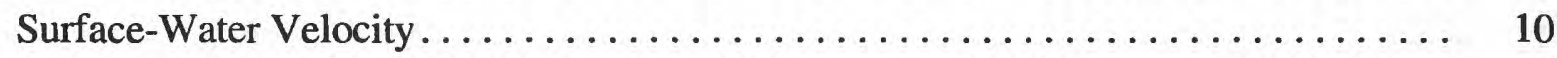

Surface-Water Depth................................. 12

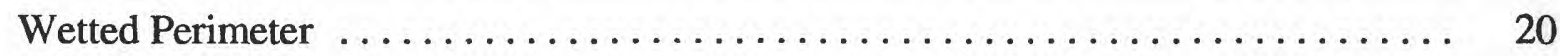

Field Water-Quality Data $\ldots \ldots \ldots \ldots \ldots \ldots \ldots \ldots \ldots \ldots \ldots \ldots \ldots \ldots \ldots \ldots \ldots \ldots \ldots \ldots, 21$

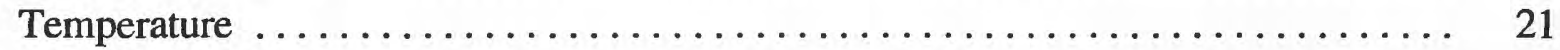

Dissolved Oxygen ................................... 21

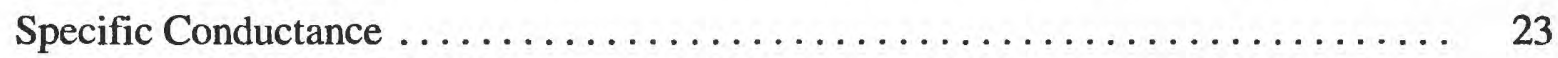

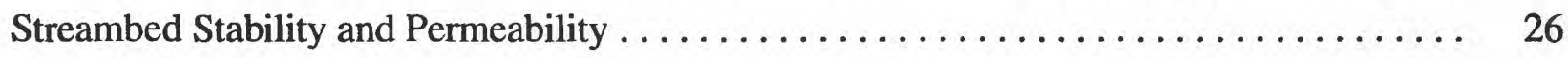

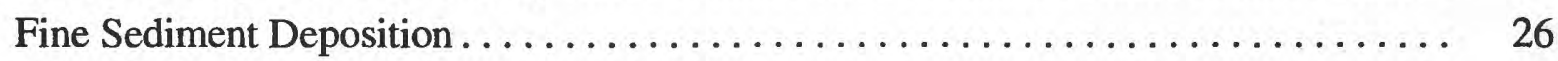

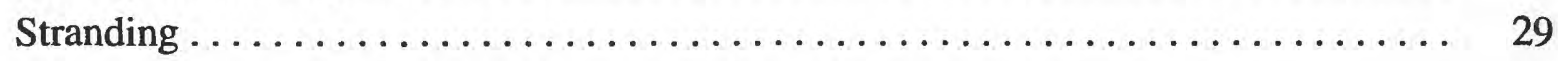

Discharge from the North and Lower Middle Forks of the Bradley River........ 29

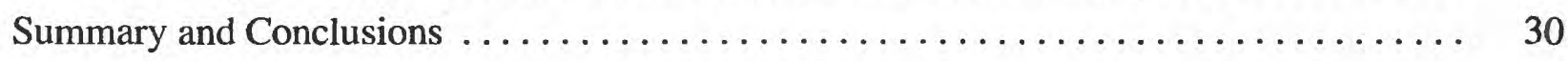

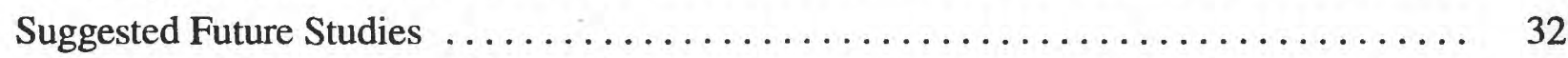

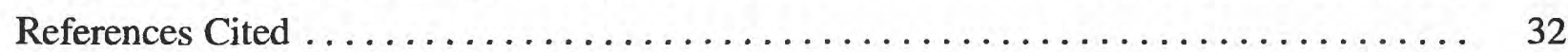


Appendix 1: Cross section and velocity distribution at selected sites in the lower Bradley River, November 1994 through April 1995.

Appendix 2: Selected hydraulic properties, water-quality data, and site characteristics for the lower Bradley River, November 1994 through April 1995

\section{FIGURES}

1. Map showing location of the Bradley Lake Hydroelectric Project area........ VI

2. Photograph showing aerial view of the study area on the lower Bradley River from Bear Island to Lower Riffle Reach .................... 5

3. Map showing Lower Bradley River study transect locations............. 6

4. Photograph showing sample tube used to collect intragravel water samples...... 9

5. Graph showing daily mean discharges for Bradley River near Tidewater....... 11

6-11. Graphs showing physical properties of Bradley River:

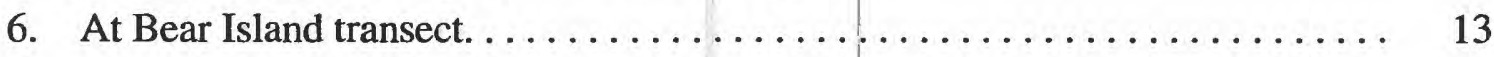

7. Near Tidewater transect............................. 14

8. At Tree Bar Reach transect ............................ 15

9. Below Fish Camp transect.......................... 16

10. At Upper Riffle Reach transect .................... 17

11. At Lower Riffle Reach transect........................ 18

12-17. Graphs showing:

12. Selected surface-water velocity distributions for the six transects in the lower Bradley River ........................... 19

13. Daily mean surface and intragravel water temperature of the Bradley River

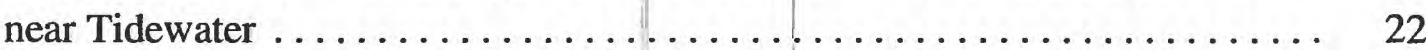

14. Dissolved oxygen concentrations at the six study transects ........... 24

15. Dissolved oxygen percent interchange at the six study transects ......... 27

16. Instantaneous discharge measurements of the Middle Fork Bradley River below North Fork Bradley River $\ldots \ldots \ldots \ldots \ldots \ldots \ldots \ldots \ldots \ldots . \quad 31$

17. Results of periodic specific conductance measurements in the Middle Fork Bradley River below North Fork Bradley River. .............. 31

\section{TABLES}

1. Types of data collected and frequency of collection in the lower Bradley River, March 1993 through April 1995

2. Gravel bar slopes at the six study transects $\ldots \ldots \ldots \ldots \ldots \ldots \ldots \ldots \ldots \ldots \ldots$ 


\begin{tabular}{rll}
\hline Multiply & by & To obtain \\
\hline inch (in.) & 25.4 & millimeter \\
foot (ft) & 0.3048 & meter \\
mile (mi) & 1.609 & kilometer \\
square foot $\left(\mathrm{ft}^{2}\right)$ & 0.0929 & square meter \\
foot per second (ft/s) & 0.3048 & meter per second \\
cubic foot per second $\left(\mathrm{ft}^{3} / \mathrm{s}\right)$ & 0.02832 & cubic meter per second \\
\hline
\end{tabular}

In this report, water temperature is reported in degrees Celsius $\left({ }^{\circ} \mathrm{C}\right)$, which can be converted to degrees Fahrenheit $\left({ }^{\circ} \mathrm{F}\right)$ by the following equation:

$$
{ }^{\circ} \mathrm{F}=1.8\left({ }^{\circ} \mathrm{C}\right)+32
$$

\section{ABBREVIATED WATER-QUALITY UNITS}

$\mathrm{mL}$, milliliter

$\mathrm{mg} / \mathrm{L}$, milligrams per liter

$\mu \mathrm{S} / \mathrm{cm}$, microsiemens per centimeter at 25 degrees Celsius

\section{VERTICAL DATUM}

Sea level: In this report, "sea level" refers to the National Geodetic Vertical Datum of 1929-A geodetic datum derived from a general adjustment of the first-order level nets of the United States and Canada, formerly called Sea Level Datum of 1929. 

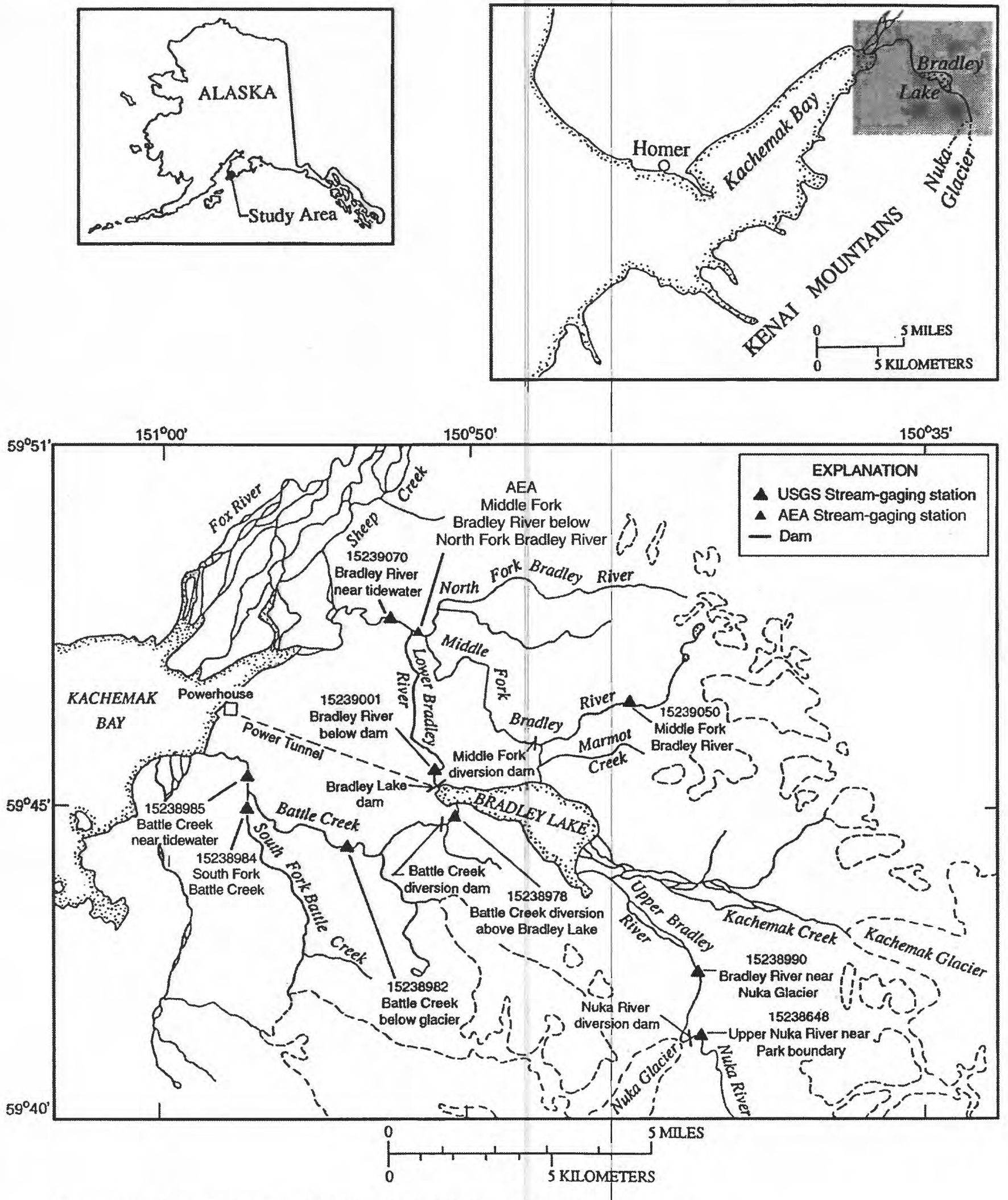

Figure 1. Location of the Bradley Lake Hydroelectric Project area. 


\title{
Effect of Ice Formation and Streamflow on Salmon Incubation Habitat in the Lower Bradley River, Alaska
}

\author{
by Ronald L. Rickman
}

\begin{abstract}
A minimum flow of 40 cubic feet per second is required in the lower Bradley River, near Homer, Alaska, from November 2 to April 30 to ensure adequate salmon egg incubation habitat. The study that determined this minimum flow did not account for the effects of ice formation on habitat. An investigation was made during periods of ice formation. Hydraulic properties and field water-quality data were measured in winter only from March 1993 to April 1995 at six transects in the lower Bradley River. Discharge in the lower Bradley River ranged from 42.6 to 73.0 cubic feet per second (average 57 cubic feet per second) with ice conditions ranging from near ice free to 100 percent ice cover. Stream water velocity and depth were adequate for habitat protection for all ice conditions and discharges. No relation was found between percent ice cover and mean velocity and depth for any given discharge and no trends were found with changes in discharge for a given ice condition. Velocity distribution within each transect varied significantly from one sampling period to the next. Mean depth and velocity at flows of 40 cubic feet per second or less could not be predicted. No consistent relation was found between the amount of wetted perimeter and percent ice cover. Intragravel-water temperature was slightly warmer than surface-water temperature. Surface and intragravel-water dissolved-oxygen levels were adequate for all flows and ice conditions. No apparent relation was found between dissolved-oxygen levels and streamflow or ice conditions. Excellent oxygen exchange was indicated throughout the study reach. Stranding potential of salmon fry was found to be low throughout the study reach. The limiting factors for determining the minimal acceptable flow limit appear to be stream-water velocity and depth, although specific limits could not be estimated because of the high flows that occurred during this study.
\end{abstract}

\section{INTRODUCTION}

\section{Location of Study Area}

The Bradley River originates in the Kenai Mountains east of Homer and flows into Bradley Lake (fig. 1), then flows northward from Bradley Lake for about $5 \mathrm{mi}$ to Kachemak Bay. The Middle and North Forks of the Bradley River flow into the main stem of the Bradley River $3.3 \mathrm{mi}$ downstream from the Bradley Lake outlet. Flow from the upper basin of the Middle Fork is diverted into Bradley Lake. The most downstream mile-long reach of the Bradley River provides habitat for five species of Pacific salmon and Dolly Varden char (Rundquist and others, 1985, p. 78).

\section{Bradley Lake Hydroelectric Project}

The Alaska Energy Authority (AEA) began operation of the Bradley Lake Hydroelectric Project near Homer, Alaska in 1991 (fig. 1). The dam, which was constructed at the Bradley Lake outlet, incorporated a fish-water bypass system to maintain flows required for fish habitat enhance- 
ment in the lower Bradley River. Project operation has resulted in reduced streamflow in the lower Bradley River during the summer, and increased flow above natural conditions during the winter (Rickman, 1993), thus improving salmon spawning and rearing habitat (Morsell and Howard, 1995).

Federal Energy Regulatory Commission (FERC) licensing requirements for the Bradley Lake Hydroelectric Project require maintenance of a minimum flow of $40 \mathrm{ft}^{3} / \mathrm{s}$ from November 2 to April 30, measured at the U.S. Geological Survey (USGS) stream-gaging station Bradley River near Tidewater (station No. 15239070). This discharge of $40 \mathrm{ft}^{3} / \mathrm{s}$ is based on an open-water instream flow study (Woodward-Clyde Consultants, 1983). The instream flow study was based primarily on egg incubation requirements of pink salmon (Oncorhynchus gorbuscha), but other salmon species and Dolly Varden char habitat requirements were also addressed. The study found little difference in usable egg incubation habitat between flows of 30 and $40 \mathrm{ft}^{3} / \mathrm{s}$, but did not account for the effects of river ice formation, which is common in the lower Bradley River during the winter months. Many studies have developed suitability criteria for salmon spawning habitats, but few have addressed salmon egg incubation habitats in ice-covered streams (Morsell, 1994). The embryos and alevins are essentially immobile, so it is important that the egg incubation habitat remain healthy throughout the winter (Rundquist and Baldrige, 1990, p. 591). Hydraulic and physical characteristics important to the incubation process are stream velocity, depth of surface water, wetted perimeter, intragravel water temperature, intragravel dissolved oxygen, specific conductance, and streambed stability and permeability.

\section{Winter Flow Conditions}

Ice formation in the lower Bradley River may cause backwater conditions leading to an increase in wetted perimeter and depth of surface water. Stream velocity may decrease, which can adversely affect dissolved-oxygen levels in surface and intragravel waters. Anchor ice may retard water and dissolved-oxygen interchange between surface and intragravel environments.

Periodic temporary dewatering of the lower Bradley River could potentially occur because of ice jamming upstream, or because of problems with the fish-water bypass system. Rapid dewatering of the stream channel may leave juvenile salmon stranded, thus killing them. Stranding frequency is inversely proportional to the slope of the dewatered gravel bars (Prewitt and Whitmus, 1986). Expansive, flat bars are associated with higher stranding rates than steeper bars, because fish may not be able to swim fast enough to remain in the water during rapid declines in stage.

Maintenance of $40 \mathrm{ft}^{3} / \mathrm{s}$ flow is difficult in the lower Bradley River during the winter months because ice formation makes it difficult to measure flow accurately. It is not practical to obtain a record of continuous river discharge directly. Instead, river stage is continuously monitored with instruments and discharges are measured at various stages to define the correlation between stage and discharge (Rantz and others, 1982). The correlation between river stage and discharge remains valid as long as the hydraulic properties do not change. Ice formation in the lower Bradley River channel causes rapid and highly variable changes in channel geometry, rendering the stage-discharge relation useless.

Operators of the Bradley hydroelectric project have released flows of $40 \mathrm{ft}^{3} / \mathrm{s}$ at the fish-water bypass (measured at the USGS gaging station Bradley River below dam, which generally remains ice free) to ensure maintenance of a flow of $40 \mathrm{ft}^{3} / \mathrm{s}$ in the lower Bradley River. However, actual 
flows in the lower Bradley River have been significantly higher than the required minimum because of inflow from the Middle and North Fork Bradley Rivers.

In March 1993, under a cooperative agreement with the Alaska Energy Authority, the USGS began a study of winter flow conditions in the lower Bradley River. Northern Ecological Services, under contract with the Alaska Energy Authority, has monitored salmon escapement in the lower Bradley River (Morsell and others, 1993; Morsell, 1994) throughout this study.

\section{Purpose and Scope}

The objectives of this study were to: (1) determine whether a flow of $40 \mathrm{ft}^{3} / \mathrm{s}$ from November 2 to April 30 provides adequate salmon egg incubation habitat protection and whether a lesser flow provides adequate protection; (2) gain insight into the minimum limits of flow that would provide some assurance of egg protection in the event of unexpected decreases in flow below the allowable minimum; and (3) determine the discharges that must be released at the fishwater bypass to maintain $40 \mathrm{ft}^{3} / \mathrm{s}$ in the lower Bradley River.

The objectives could not be met because target flow conditions were not reached between March 1993 and April 1995. The project has been extended through 1998 in order to observe target flow conditions. This interim report describes activities through April 1995.

The report discusses critical habitat needs of pink salmon from egg incubation to the juvenile stage. It also describes hydraulic properties and water-quality characteristics with respect to stream discharge and ice conditions, and their potential impact on the habitat at six transects in the lower Bradley River for the periods March 1993 through April 1994, and November 1994 through April 1995. Fine-sediment deposition and dissolved-oxygen interchange between surface water and intragravel water are discussed. Stranding potential at each of the six transects, and flow contributions from the Middle Fork Bradley River below the North Fork Bradley River are presented. This report also summarizes data collected from November 1994 through April 1995 at selected sites in the lower Bradley River (appendixes 1 and 2). A previous report summarizes hydraulic and waterquality data collected from March 1993 through April 1994 (Rickman, 1995). The types of data collected and the frequency of collection are shown in table 1.

\section{Acknowledgments}

The author gratefully acknowledge the assistance of John Morsell, of Northern Ecological Services (under contract with the Alaska Energy Authority), for assisting with field studies and providing salmon escapement information.

\section{DESCRIPTION OF STUDY AREA}

An aerial view of the study area is shown in figure 2. Six transects were selected at known spawning areas of pink salmon (Morsell and others, 1993) in the lower Bradley River between Bear Island and Lower Riffle Reach (fig. 3). Stream-water discharge measurements were made on the Middle Fork Bradley River below North Fork Bradley River. Site characteristics of each transect and the Middle Fork Bradley River below North Fork Bradley River are described below. 
Table 1. Types of data collected and the frequency of collection in the lower Bradley River, March 1993 through April 1995.

\begin{tabular}{|c|c|c|c|c|c|c|c|}
\hline \multirow{2}{*}{ Type of data collected } & 1993 Water year & \multicolumn{4}{|c|}{1994 Water year } & \multicolumn{2}{|c|}{1995 Water year } \\
\hline & $\overline{M A M J J A S}$ & $O N$ & $\mathrm{D} \mathrm{J}$ & F M A M J J & AS & OND JF & $\overline{M A}$ \\
\hline $\begin{array}{l}\text { Daily mean discharge at stream-gaging } \\
\text { station Bradley River near Tidewater }\end{array}$ & $\times \times \times \times \times \times \times$ & $\mathrm{X} \mathrm{X}$ & $\mathrm{XX}$ & $\times \times \times \times \times x$ & $\mathrm{XX}$ & $\mathrm{X} \times \mathrm{X} \times$ & $\mathrm{xx}$ \\
\hline Instantaneous discharge measurements ${ }^{1}$ & $\mathrm{x}$ & & $\mathrm{x}$ & $\mathrm{x}$ & & $\mathrm{x} \times \mathrm{x}$ & $\mathrm{X} \mathrm{X}$ \\
\hline $\begin{array}{l}\text { Hydraulic measurements (wetted perimeter, } \\
\text { depth, and velocity distribution) }{ }^{2}\end{array}$ & $\mathbf{x}$ & & $\mathrm{x}$ & $\mathrm{X}$ & & $\mathrm{x} \times \mathrm{X}$ & $\mathrm{X} \times$ \\
\hline $\begin{array}{l}\text { Surface and intragravel water } \\
\text { temperature }^{3}\end{array}$ & $\mathbf{x}$ & & $\mathrm{x}$ & $\mathrm{X}$ & & $\mathrm{X} \times$ & $\mathrm{X} \times$ \\
\hline $\begin{array}{l}\text { Surface and intragravel water dissolved } \\
\text { oxygen at the six transects } \\
{ }^{3}\end{array}$ & $\mathrm{x}$ & & $\mathrm{x}$ & $\mathbf{x}$ & & $\mathrm{X} \times$ & $\mathrm{X} \times$ \\
\hline Surface-water specific conductance ${ }^{1}$ & $\mathrm{x}$ & & $\mathrm{x}$ & $\mathrm{x}$ & & $\mathrm{x} \mathrm{X}$ & $\mathrm{X} \times$ \\
\hline Estimate percent ice cover ${ }^{2}$ & $\mathrm{x}$ & & $\mathrm{x}$ & $\mathrm{x}$ & & $\mathrm{X} \times$ & $\mathrm{X} \times$ \\
\hline Substrate size classification ${ }^{2}$ & & & & & $\mathrm{x}$ & & \\
\hline $\begin{array}{l}\text { Photographs to document ice conditions } \\
\text { at time of field measurements }{ }^{2}\end{array}$ & $\mathrm{x}$ & & $\mathrm{x}$ & $\mathrm{x}$ & & $\mathrm{x} \times$ & $\mathrm{X} \times$ \\
\hline
\end{tabular}

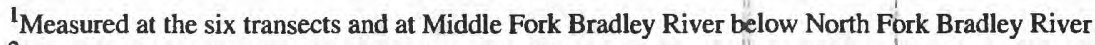

${ }^{2}$ Measured at the six transects

${ }^{3}$ Field surface-water temperature measured at all transects; hourly recording of surface-water and intragravel water temperature measured at sensor sites near the Tidewater and Tree Bar Reach transects, respectively, throughout the entire study period. Field intragravel-water temperature measured only when calibrating intragravel temperature probe.

\section{Bear Island}

This transect, located near the mid-point of Bear Island, is near the upstream boundary of the usable spawning habitat (fig. 3). A waterfall approximately $500 \mathrm{ft}$ upstream from this transect prevents salmon from moving farther upstream. The transect is at a transition from pool to riffle and is characterized by shallow sloped gravel bars on both right and left banks (fig. A, appendix 1). A small narrow gravel bar near the right bank splits the river into two channels; only a small portion of the total flow passes through the right channel. The river channel is wider at the Bear Island transect than at the other five transects. Substrate is composed of large cobbles to medium-sized gravels, with a median diameter of $0.22 \mathrm{ft}$. This transect is not affected by high tides.

\section{Tidewater}

The Tidewater transect is located approximately $100 \mathrm{ft}$ below Bear Island, and $35 \mathrm{ft}$ below the USGS stream-gaging station Bradley River near Tidewater (fig. 3). The transect is located at a poolto-riffle transition area, and is characterized by a steep root mass and soil on the right bank and a steep gravel bar on the left bank (fig. B, appendix 1). The channel at this transect is narrower than at the other five transects. Substrate ranges from large cobbles to medium gravel with a median diameter of $0.26 \mathrm{ft}$. This transect is affected by extreme high tides, which occur on three to five days each month. A surface-water temperature sensor located near the gaging station records the temperature every hour. 


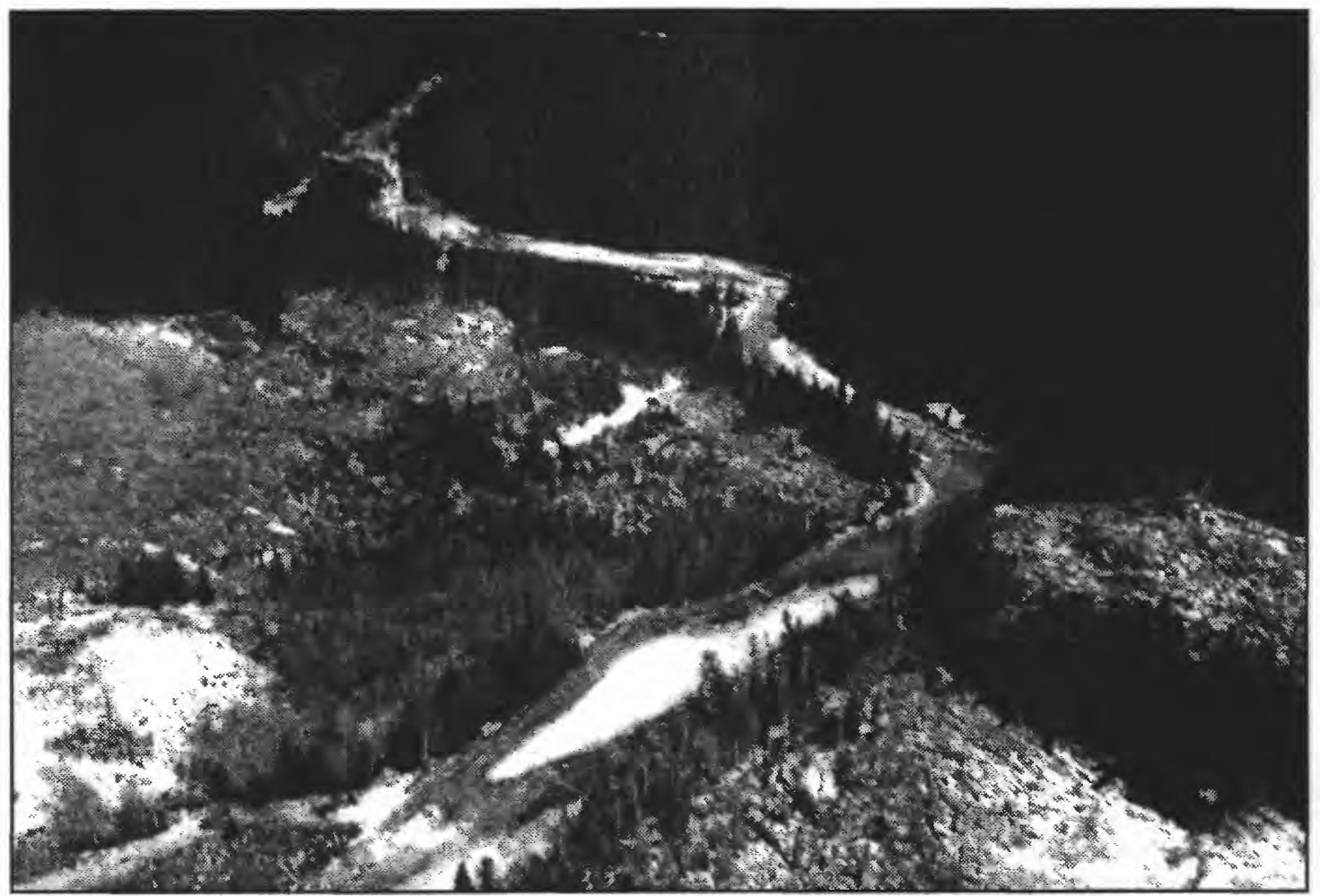

Figure 2. Aerial view of the study area on the lower Bradley River from Bear Island (upper left) to Lower Riffle Reach (bottom center).

\section{Tree Bar Reach}

Tree Bar Reach (fig. 3), located $280 \mathrm{ft}$ downstream from the Tidewater transect, is characterized by a moderately wide channel with a flat bottom. The transect is located in the midpoint of a long riffle. The right bank consists of steep sloped gravel overlain with roots and soil. The left bank is a relatively steep gravel bar. A small abandoned overflow channel is located along a bedrock wall on the far left side of the canyon (fig. C, appendix 1). Substrate ranges from medium cobbles to medium gravel with a median diameter of $0.10 \mathrm{ft}$. This transect is affected by extreme high tides on five to seven days each month. An intragravel temperature sensor, buried to a depth of $1 \mathrm{ft}$ below the streambed, is located $10 \mathrm{ft}$ downstream from this transect.

\section{Below Fish Camp}

Below Fish Camp transect (fig. 3) is approximately $150 \mathrm{ft}$ downstream from the fish camp and $500 \mathrm{ft}$ downstream from the Tree Bar Reach transect. The transect is in a riffle-to-pool transition area and is characterized by moderately sloped gravel bars on both the right and left banks. A small slough on the extreme right edge of the channel remained dry during the study period (fig. $\mathrm{D}$, appendix 1). The channel is moderately wide. Substrate consists mostly of gravel with some cobbles. The median diameter of the substrate is $0.07 \mathrm{ft}$. This transect is affected by medium and extreme high tides on approximately 10 to 14 days each month. 


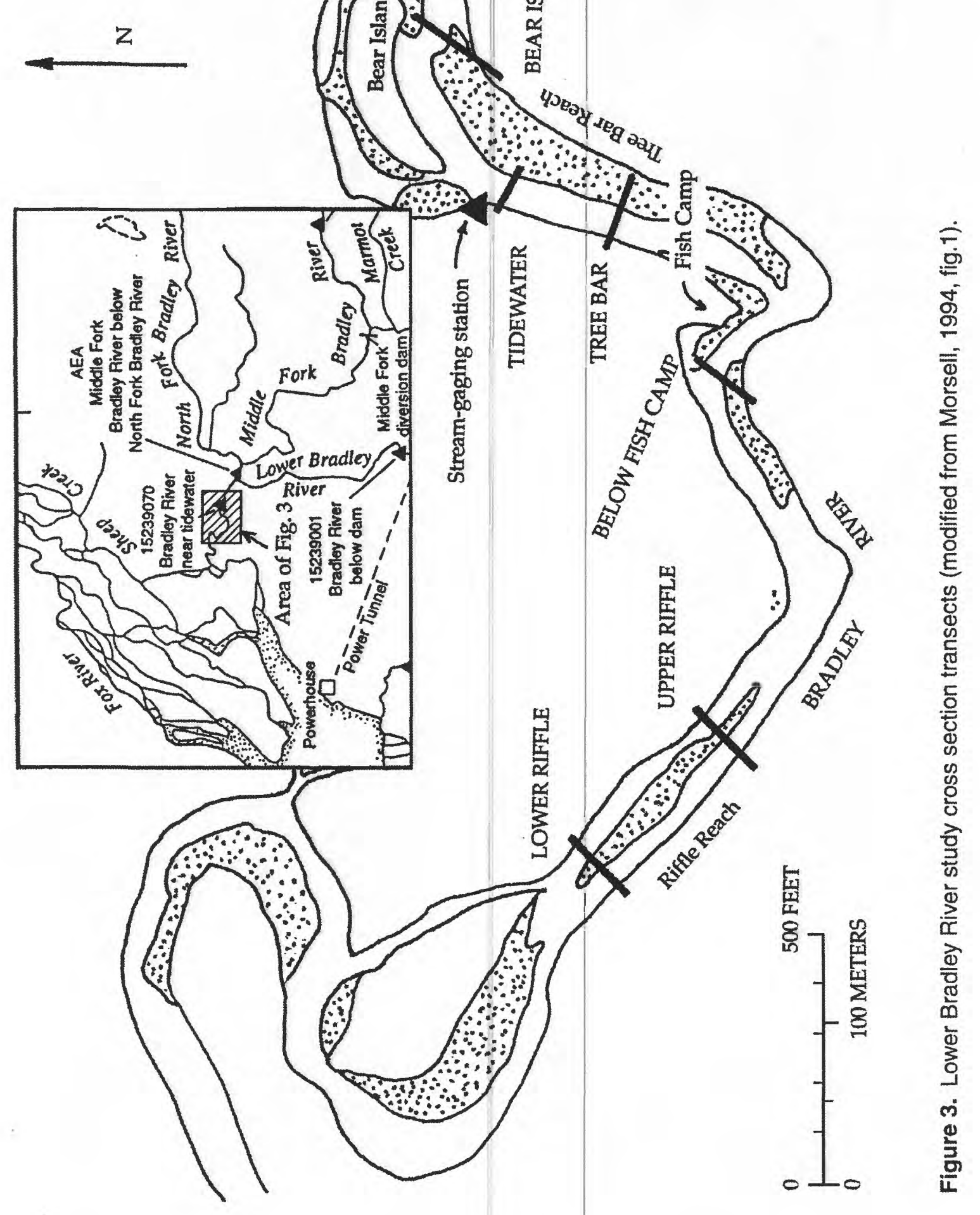




\section{Upper Riffle Reach}

The Upper Riffle Reach transect is located approximately $850 \mathrm{ft}$ downstream from the Below Fish Camp transect, in a deep riffle (fig. 3). The river is split by a gravel bar into two channels of approximately equal width. The right channel is deeper than the left channel (fig. E, appendix 1). The right bank of the right channel is vertical and composed of tree roots and soil. The left bank of the right channel and the right bank of the left channel are formed by moderately steep sloped gravel bars which are covered sparsely with grass. The left bank of the left channel is steep sloped and composed of tree roots and soil. The median diameter of the substrate is $0.17 \mathrm{ft}$ in the right channel and $0.23 \mathrm{ft}$ in the left channel. During much of the winter, mud covers the substrate of approximately 25 percent of both channels, usually near the gravel bar. The mud is carried in from Kachemak Bay during extreme high tide. This transect is affected by backwater from high tide on most days during the winter.

\section{Lower Riffle Reach}

The Lower Riffle Reach transect is located $350 \mathrm{ft}$ downstream from the Upper Riffle Reach transect, in a deep riffle, and defines the lower boundary of the study area (fig. 3 ). The river forms two channels separated by a gravel bar. The right channel is narrower and deeper than the left channel (fig. F, appendix 1). The right bank of the right channel is vertical and is composed of tree roots and soil. The left bank of the right channel and the right bank of the left channel are formed by moderately steep sloped gravel bars which are covered sparsely with grass. The left bank of the left channel is steep sloped and is composed of tree roots and soil. The median diameter of the substrate is $0.10 \mathrm{ft}$ in the right channel and $0.13 \mathrm{ft}$ in the left channel. During much of the winter, mud covers the substrate in approximately 25 percent of both channels, usually near the gravel bar. Mud is carried in from Kachemak Bay during extreme high tide. This transect is affected by backwater from high tide on most days during the winter.

\section{Middle Fork Bradley River Below North Fork Bradley River}

A discharge measuring section was established at the Alaska Energy Authority (AEA) stream-gaging site (fig. 1). The river flows through a deep narrow canyon. The river channel consists of deep pools and small waterfalls. Both riverbanks consist of bedrock, and the channel bottom is composed of medium gravels and small boulders. No fish are in this drainage basin because obstructions downstream from the confluence with the main stem of the Bradley River prevent fish from moving upstream. Ice forms in the river in early November and remains through mid-April.

\section{METHODS AND MATERIALS}

\section{Measurements of Surface Water}

Measurements of streamflow were made using standard methods (Rantz and others, 1982). Photographic points were established for each transect in the lower Bradley River, and photographs were taken to document ice conditions at the time streamflow measurements were made. Transects were tied to a common vertical datum for determination of water-surface elevation (Rickman, 1995). Gravel bar slopes were measured at each transect using standard surveying techniques to estimate stranding potential. Rates of gage-height change-important to the understanding of 
stranding potential - were calculated from the stage hydrographs obtained from the USGS streamgaging station Bradley River near Tidewater (station No. 15239070). Hydraulic properties of water velocity and depth were obtained from streamflow measurements, and wetted perimeter was calculated using the Slope- Area Computation (SAC) program (Fulford, 1994). Wetted perimeter, as used in this report, refers to the length of interface of the water/streambed boundary, and does not include the ice/water boundary.

Water temperature was recorded at 1-hour intervals near the Tidewater transect, and water temperatures were measured periodically at all transects and at the Middle Fork Bradley River below North Fork Bradley River, using standard methods (Stevens and others, 1975). Specific conductance was measured according to methods described by Hem (1985) at all six transects to gain insight into ground-water contributions (Riggs, 1972, p. 12; Miller and others, 1988) and possible salt-water intrusion from high tides. Dissolved-oxygen concentration was determined using the modified Winkler method (American Public Health Association and others, 1989, p. 4-152). Barometric pressure was also measured concurrently to calculate the percent oxygen saturation. Duplicate measurements of water temperature, dissolved oxygen, and specific conductance were made on 16 percent of the measurements. Measurements of water temperature, dissolved oxygen, and specific conductance were made at several points across each transect, one time only, to determine variability within the transect.

\section{Measurement of Intragravel Water}

Intragravel water is defined as the fluid occupying the porous interior of the streambed. For this study, it was the interstitial water collected from 8 to 12 in. below the streambed surface-the depth of buried eggs-for physical and chemical analysis. Water-temperature data were collected at 1-hour intervals throughout the study near the Tree Bar Reach transect, using standard methods (Stevens and others, 1975). The temperature probe was buried to a depth of 12 in., but this depth varied slightly during the study period because of scour and fill of the streambed.

Dissolved-oxygen samples were collected using special equipment and procedures that differ from those commonly used for fisheries studies. This was necessary to collect representative samples. The samples were collected by inserting a stainless-steel tube with an inside diameter of $3 / 16$ in. through a hole drilled in the ice and into the streambed to a depth of $12 \mathrm{in}$. The lower $4 \mathrm{in}$. of the sample tube was perforated with $1 / 16$ inch diameter holes, enabling water samples to be collected between 8 and $12 \mathrm{in}$. below the streambed (fig. 4). Water was pumped at a rate of 10 to $15 \mathrm{~mL}$ per minute into a 60 -mL biochemical oxygen demand (BOD) bottle. The slow pump rate was necessary to prevent surface-water intrusion (Hoffman, 1986, p. 446). A total of three sample volumes were pumped through the bottles, and the samples were fixed and analyzed using the azide modification of the Winkler method. The pump, tubing, and BOD bottle were placed in a $2^{\circ} \mathrm{C}$ waterbath to keep from freezing whenever the air temperature was below $0^{\circ} \mathrm{C}$. Silt content in dissolved-oxygen samples was recorded; depth and velocity of surface water at the sample sites were also recorded. Water temperature was measured at the Tree Bar Reach transect using the intragravel temperature probe. This transect is the only one where intragravel water percent oxygen saturation was calculated. The percent dissolved-oxygen interchange between surface and intragravel water was calculated (Woods, 1980). 


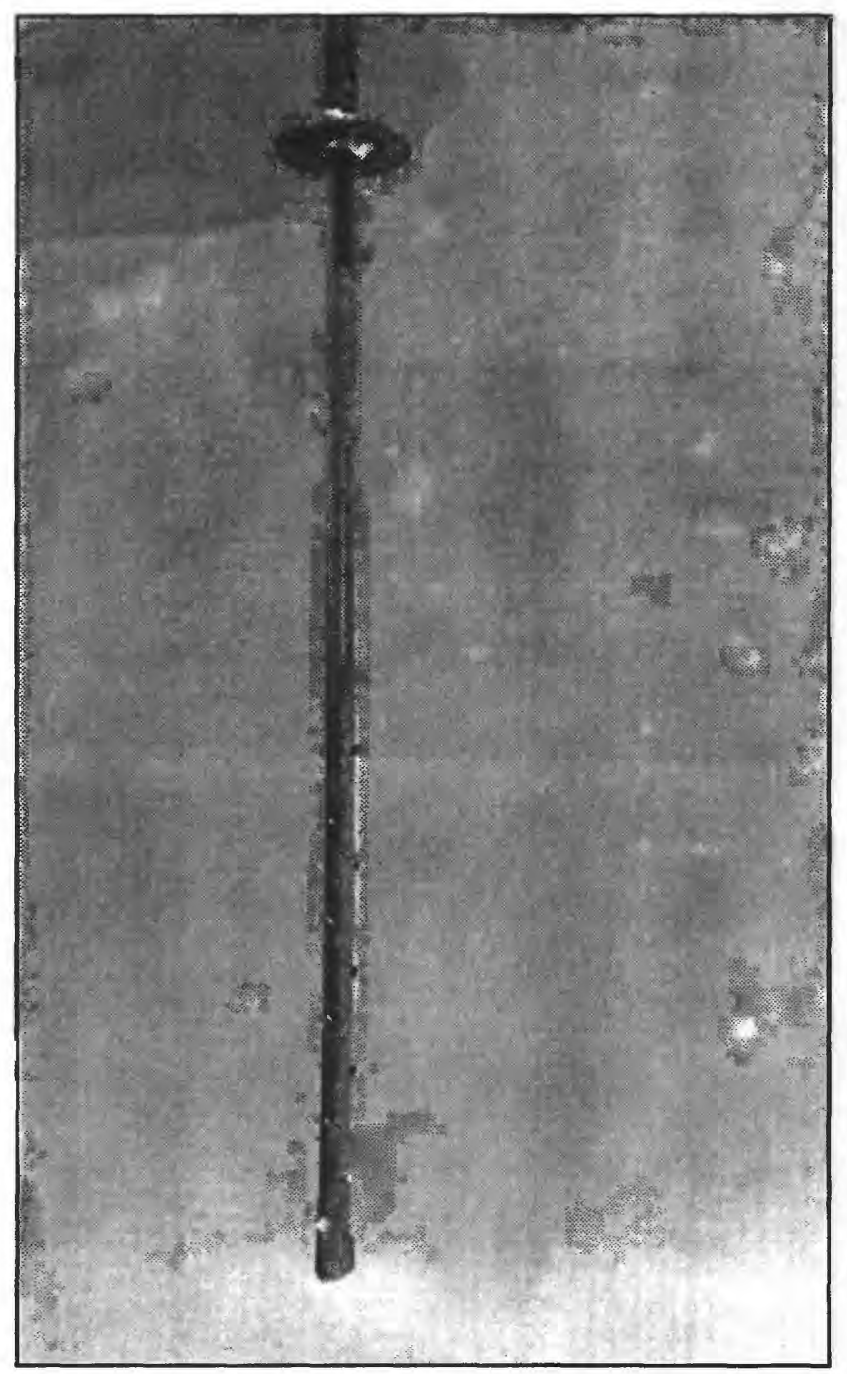

Figure 4. Sample tube used to collect intragravelwater samples (height of tube from ring to bottom is 1 foot).

\section{Observation Methods of Spawning Area Locations and Population Estimates}

Active spawning areas were located and monitored by Northern Ecological Services of Anchorage, Alaska, under contract to the Alaska Energy Authority, from mid-July through early September 1993-95. Seine nets and trap nets were positioned in active spawning areas to sample fish populations. Salmon population and escapement were estimated and compared with preproject data (Morsell and others, 1993; Morsell, 1994). 


\section{ICE FORMATION AND STREAMFLOW}

Pink salmon (Oncorhynchus gorbuscha) move into the lower Bradley River to spawn from mid-July to early September with the highest concentration about mid-August (Morsell and others, 1993). The female digs a nest (redd) in the stream gravels, lays the eggs at an average depth of approximately $12 \mathrm{in}$., and covers them with gravel. The alevins emerge sometime in January and remain in the gravel through the winter (John Morsell, Northern Ecological Services, oral. commun., 1995). The exact time of emergence in the lower Bradley River is unknown, but is suspected to be in late March and early April. The lower Bradley River has ice formation during much of the egg incubation, hatching, and alevin development stages.

Ice formation in the lower Bradley River, measured at the stream-gaging station Bradley River near Tidewater (station No. 15239070), was intermittent during the study period (fig. 5). The period of March 1 to April 30, 1993 was mostly ice free, with a few days of shore ice formation (Linn and others, 1994). The November 1, 1993 through April 30, 1994 period was ice affected approximately 50 percent of the time (Bigelow and others, 1995). Ice formation during this period was usually shore ice, with short periods of complete ice cover in mid-January and late February. Ice formed in the lower Bradley River approximately 70 percent of the time between November 1 , 1994 and April 30, 1995 (Schellekens and others, 1996). The river was completely ice covered during much of this period.

Discharge in the lower Bradley River ranged from 42,7 to $73 \mathrm{ft}^{3} / \mathrm{s}$ ( 7 to 83 percent higher than the target flow of $40 \mathrm{ft}^{3} / \mathrm{s}$ ) during the study period. The average discharge was $57 \mathrm{ft}^{3} / \mathrm{s}$ throughout the study. Estimation of the effects of a discharge of $40 \mathrm{ft}^{3} / \mathrm{s}$ or less on the fish habitat was difficult because of the high flows that occurred during the study period. The remainder of this report will highlight the knowledge obtained from the higher flow data.

\section{HYDRAULIC PROPERTIES}

Selected hydraulic properties of the transects in the lower Bradley River from March 1993 to April 1994 have been previously reported (Rickman, 1995). Selected hydraulic properties from November 1994 to April 1995 are presented in appendix 2 (table A1).

\section{Surface-Water Velocity}

Adequate surface-water velocity is necessary during the winter to prevent freezing of the streambed gravels and to assure adequate incubation success. Surface-water velocity has a direct relation to intragravel water velocity, which is important for supplying dissolved oxygen to the eggs and removing metabolic wastes (Wickett, 1954, p. 945; Coble, 1961, p. 469; Vaux, 1968, p. 479; Johnson, 1980, p. 156). Winter surface-water velocities needed for pink salmon egg incubation and fry development have been reported as 0.5 to $8 \mathrm{ft} / \mathrm{s}$ (Woodward-Clyde, 1983, p. 47) and greater than $1 \mathrm{ft} / \mathrm{s}$ (Reiser and White, 1981). The instream/flow model used by Woodward-Clyde (1983, p. a5) chose 0.5 to $8.0 \mathrm{ft} / \mathrm{s}$ as the optimum velocities for embryo development.

Mean surface-water velocities measured in the lower Bradley River ranged from $0.33 \mathrm{ft} / \mathrm{s}$ at Upper Riffle Reach on January 12, 1995 (discharge $50.5 \mathrm{ft}^{3} / \mathrm{s}$ ) to $1.48 \mathrm{ft} / \mathrm{s}$ at the near Tidewater transect on December 3, 1993 (discharge $65 \mathrm{ft}^{3} / \mathrm{s}$; Rickman, 1995, p. 6). The average mean velocity for all transects during this study was $0.92 \mathrm{ft} / \mathrm{s}(n=36)$. 


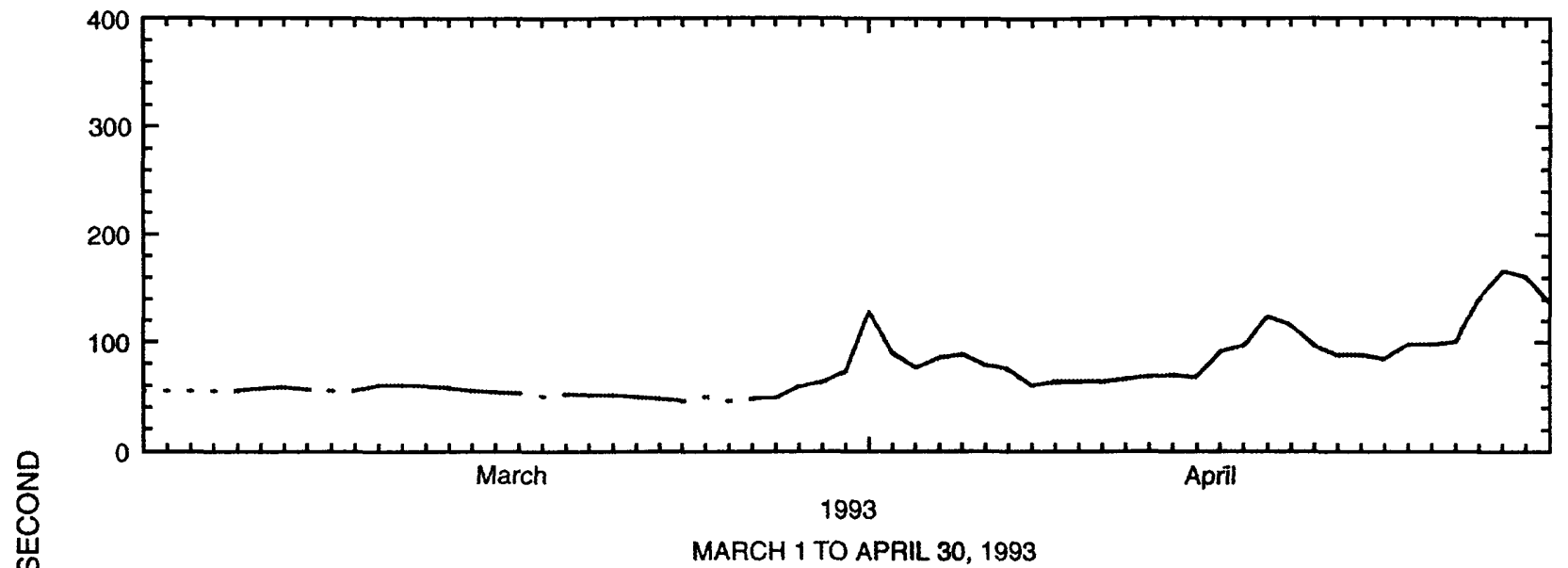

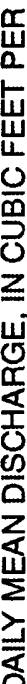

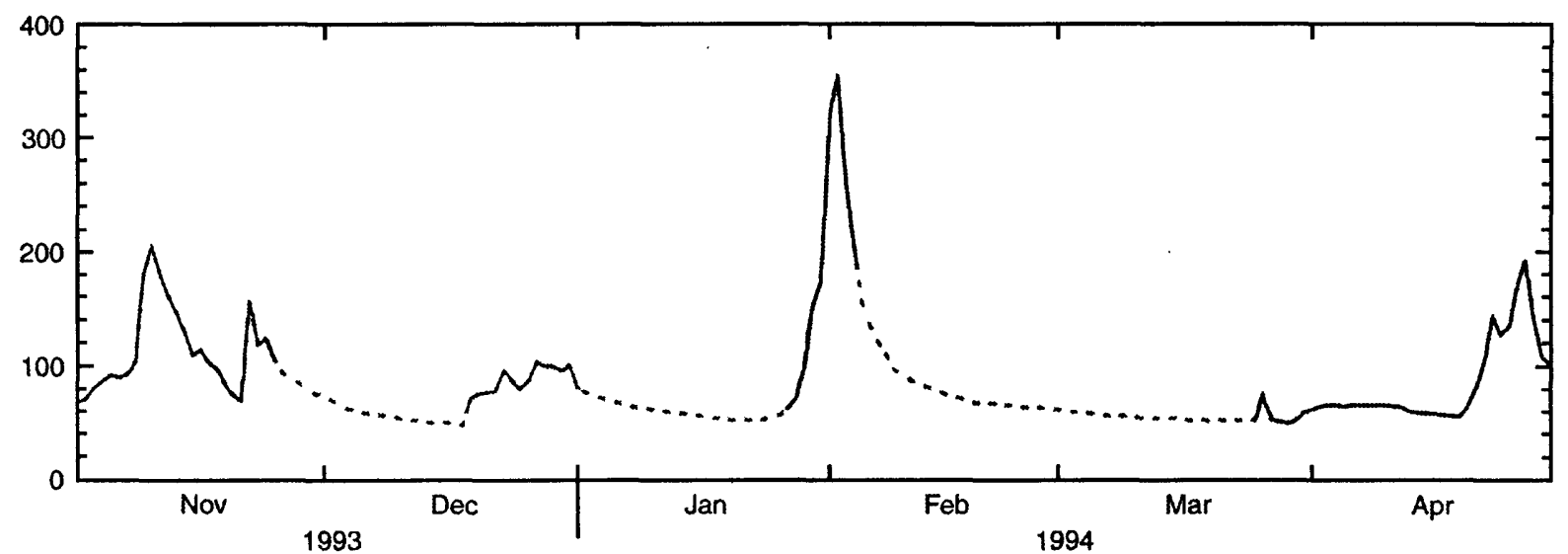

NOVEMBER 1, 1993 TO APRIL 30, 1994

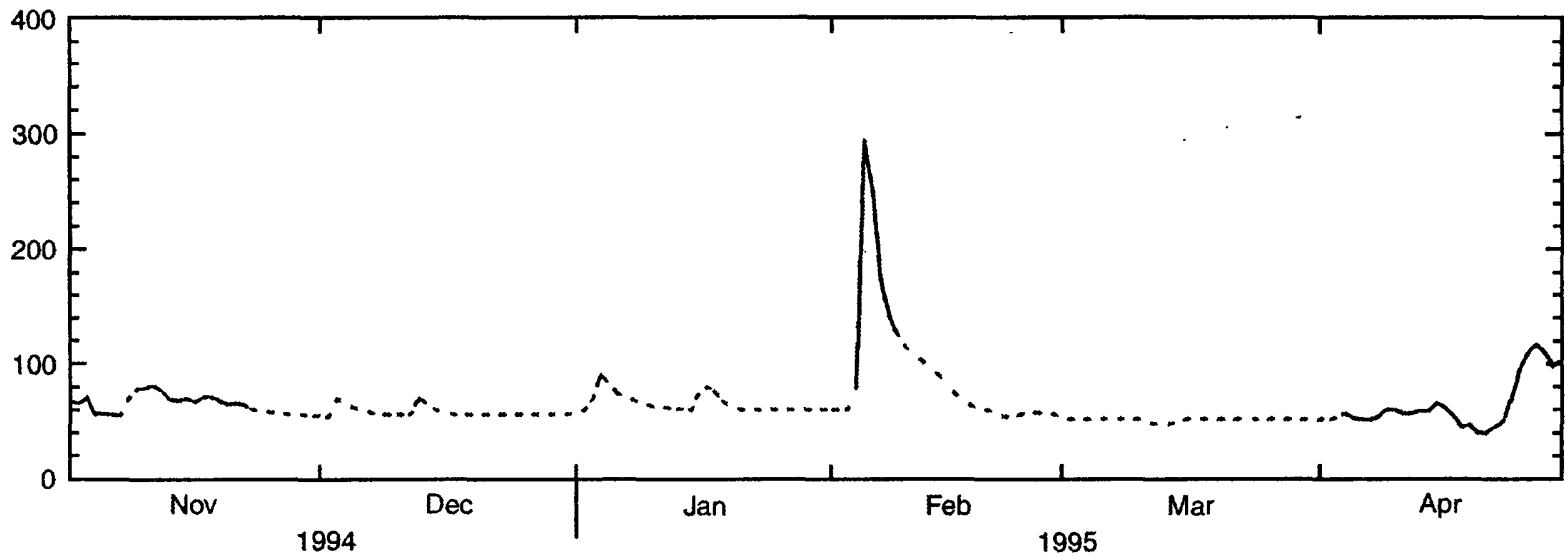

NOVEMBER 1, 1994 TO APRIL 30, 1995

EXPLANATION

Dashed line indicates estimated discharge due to ice formation

Figure 5. Daily mean discharges for Bradley River near Tidewater (station number 15239070). 
The relations between discharge, percent ice cover, and mean velocity were not always obvious. Mean velocities plotted against discharge for varying ice conditions (figs. 6A-11A) highlight this ambiguous relation. Mean velocity was expected to decrease with increased ice cover for any given discharge, but this was not always the case. Mean velocities for ice cover of 80 to 100 percent were smaller than those for ice cover of 30 percent or less, at both Bear Island and Tidewater transects, but this pattern does not hold for the other transects. Mean velocity did decrease significantly during periods of rapid ice formation, such as that measured on January 11-12, 1995 (table A1, appendix 2). At this time, formation of anchor ice, as well as surface ice, significantly increased channel friction and resulted in lower mean velocities. The January 11-12, 1995 episode is typical of early stages of ice development. Eventually, the river reaches a steady-state condition where no additional ice is formed. The soft anchor ice is then eroded away leaving only the harder surface ice. Such were the conditions at all six transects during February and December 1994, and from February to March 1995. Mean velocity was expected to decrease with decreasing discharge for a given percent ice cover, but no consistent relation is apparent for any of the cross sections.

Surface-water velocities typically increased with increasing total water-column depth (measured from streambed to water surface) within each transect, except during periods of rapid ice formation (figs. A-F, appendix 1; Rickman, 1995). Velocity distribution within each transect also varied significantly with changing ice conditions. Selected surface-water velocity distributions for the six transects in the lower Bradley River are shown in figure 12. Each episode of ice formation causes different and unique velocity distributions. This is most apparent at the Bear Island and Tree Bar Reach transects (figs. 12A and 12C). None of the observed velocities were high enough to cause channel scour, but higher velocities may have occurred between observations.

Surface-water velocities within each transect appear to be adequate for the discharges noted during this study, regardless of ice conditions. However, velocity predictions at discharges of $40 \mathrm{ft}^{3} / \mathrm{s}$ or less cannot be made because the discharges during this study were too high to allow reasonable extrapolation to lesser discharges.

\section{Surface-Water Depth}

Adequate surface-water depth is necessary to ensure that enough hydrostatic pressure exists to force movement of intragravel water needed to supply dissolved oxygen to the eggs and alevins, and to remove metabolic waste (Reiser and White, 1981). Reported depths required for pink salmon incubation range from greater than $0.2 \mathrm{ft}$ (Woodward-Clyde, 1983, p. A5) to greater than $0.5 \mathrm{ft}$ (Reiser and White, 1981; Morsell, 1994, p. 3). Woodward-Clyde used $0.2 \mathrm{ft}$ as the minimum allowable depth for adequate embryo development for their instream flow model. Data of surfacewater depth for March 1993 to April 1994 have been previously reported (Rickman, 1995). Data for November 1994 through April 1995 are presented in appendixes 1 (figs. A-F) and 2 (table Al).

Mean depths ranged from $0.55 \mathrm{ft}$ at the Lower Riffle Reach transect (November 30, 1994, discharge $46.8 \mathrm{ft}^{3} / \mathrm{s}$ ) to $1.95 \mathrm{ft}$ at the below Fish Camp transect (January 12, 1995, discharge $42.6 \mathrm{ft}^{3} / \mathrm{s}$ ) and were usually smallest at the Lower Riffle Reach transect (fig. 11B). Within each transect, depths were less than $0.2 \mathrm{ft}$ near the streambanks. Mean depths at all the transects were slightly larger than those predicted using the instream flow model for flows between 40 and $50 \mathrm{ft}^{3} / \mathrm{s}$. This may be due to channel changes resulting from the floods of October and December 1986. 

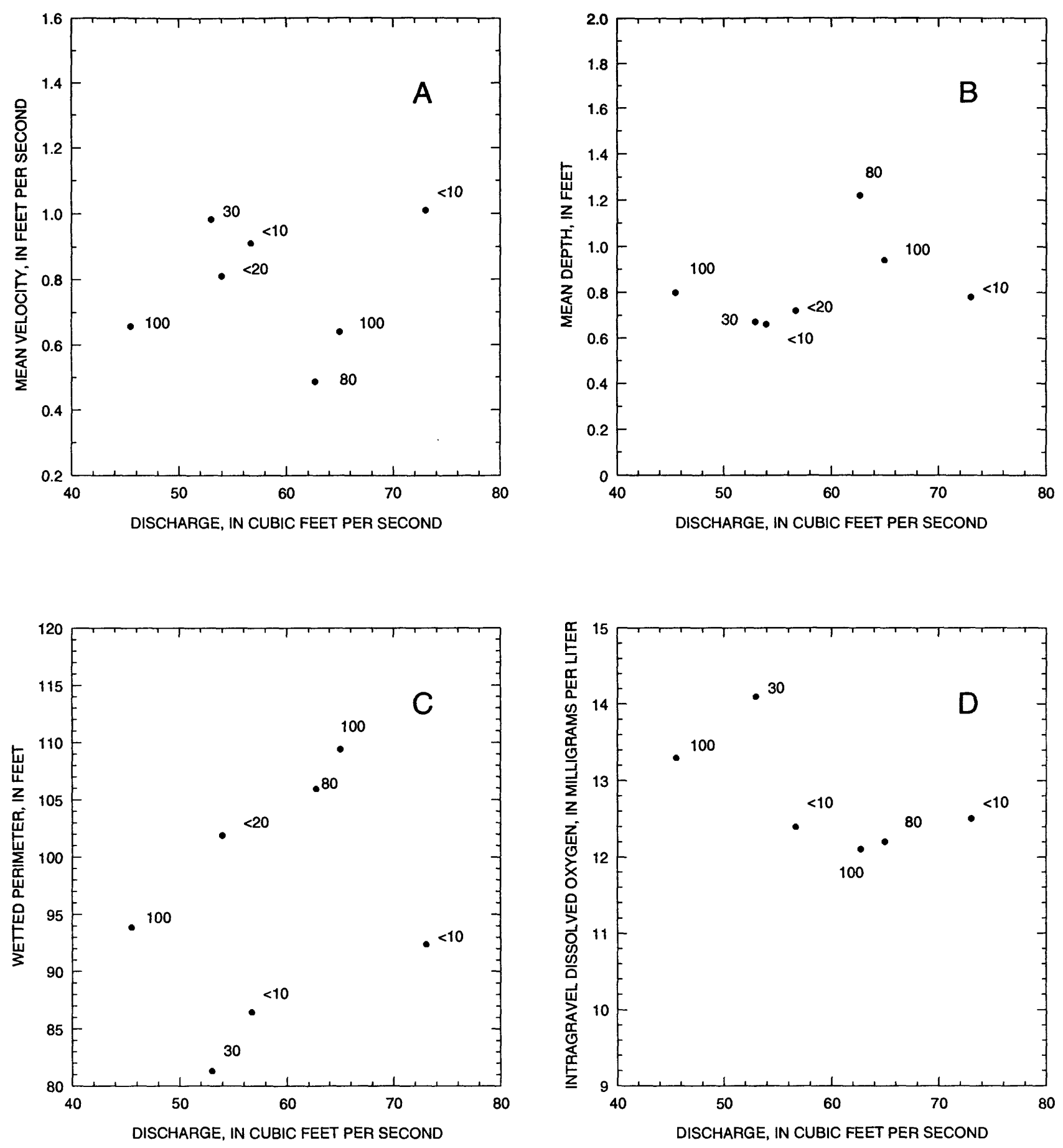

EXPLANATION

.$^{100}$ data point and percent ice cover at time of measurement

Figure 6. Physical properties of Bradley River at Bear Island transect. 

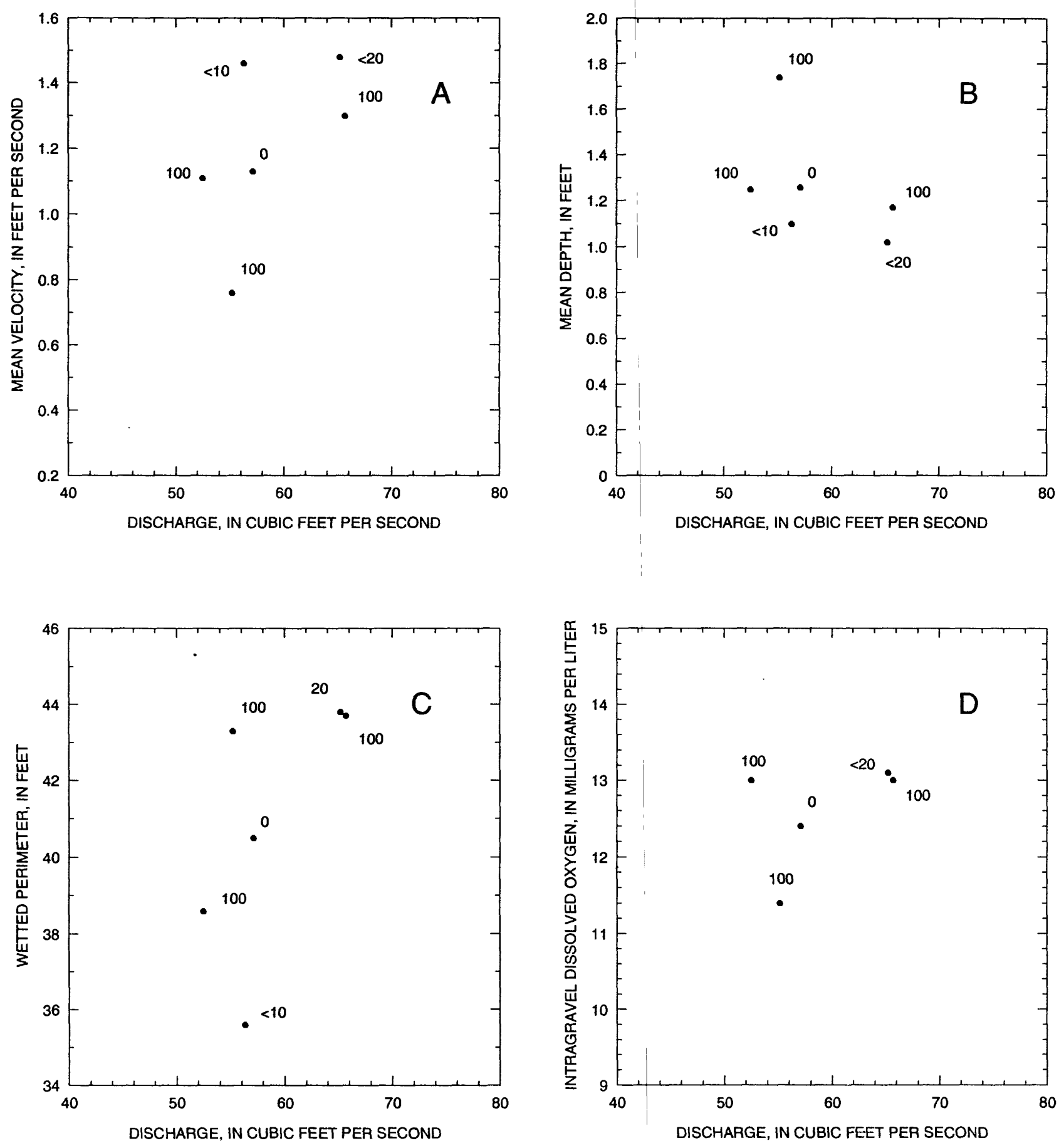

EXPLANATION

- 100 data point and percent ice cover at time of measurement

Figure 7. Physical properties of Bradley River near Tidewater transect. 

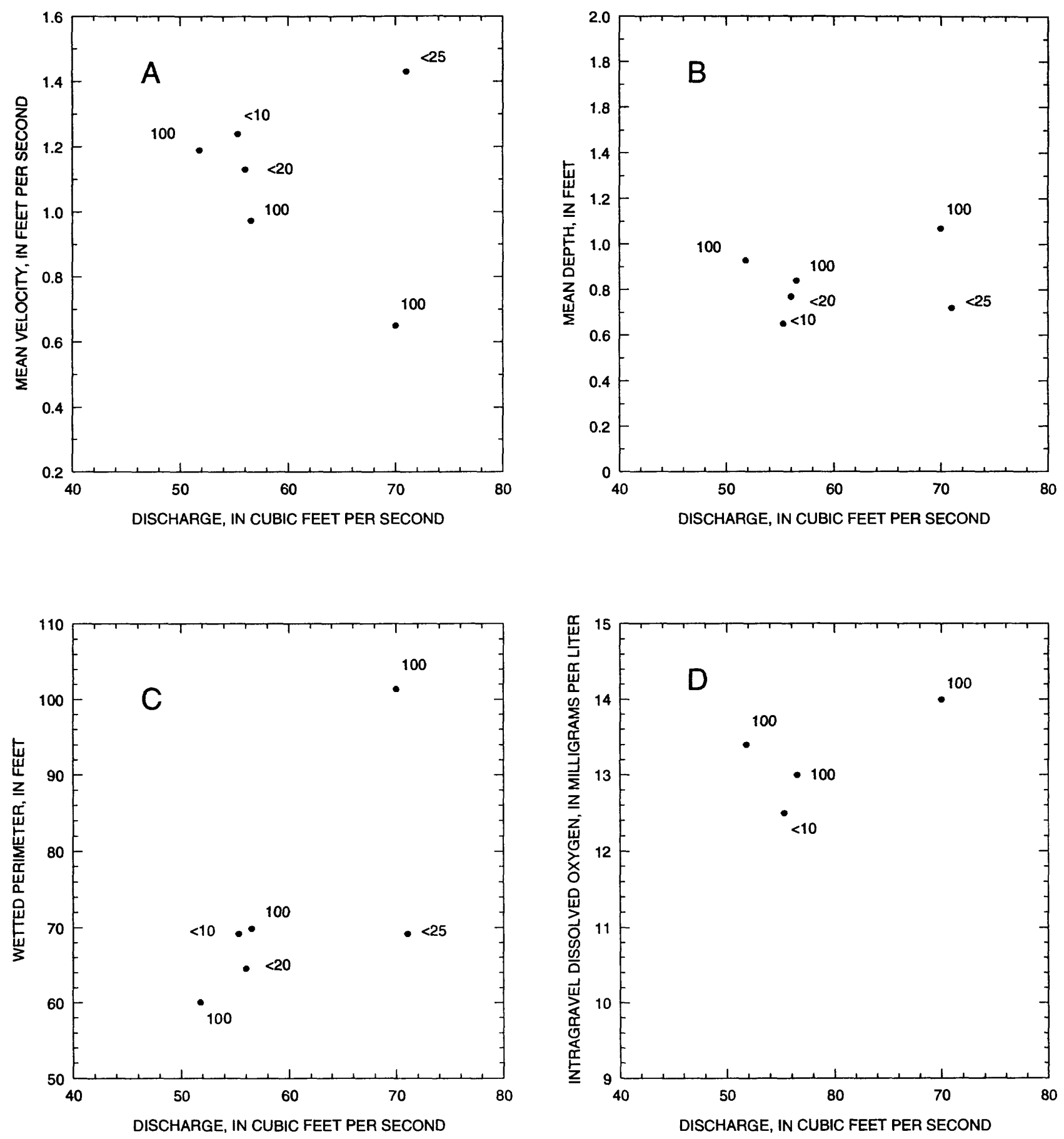

EXPLANATION

- 100 data point and percent ice cover at time of measurement

Figure 8. Physical properties of Bradley River at Tree Bar Reach transect. 

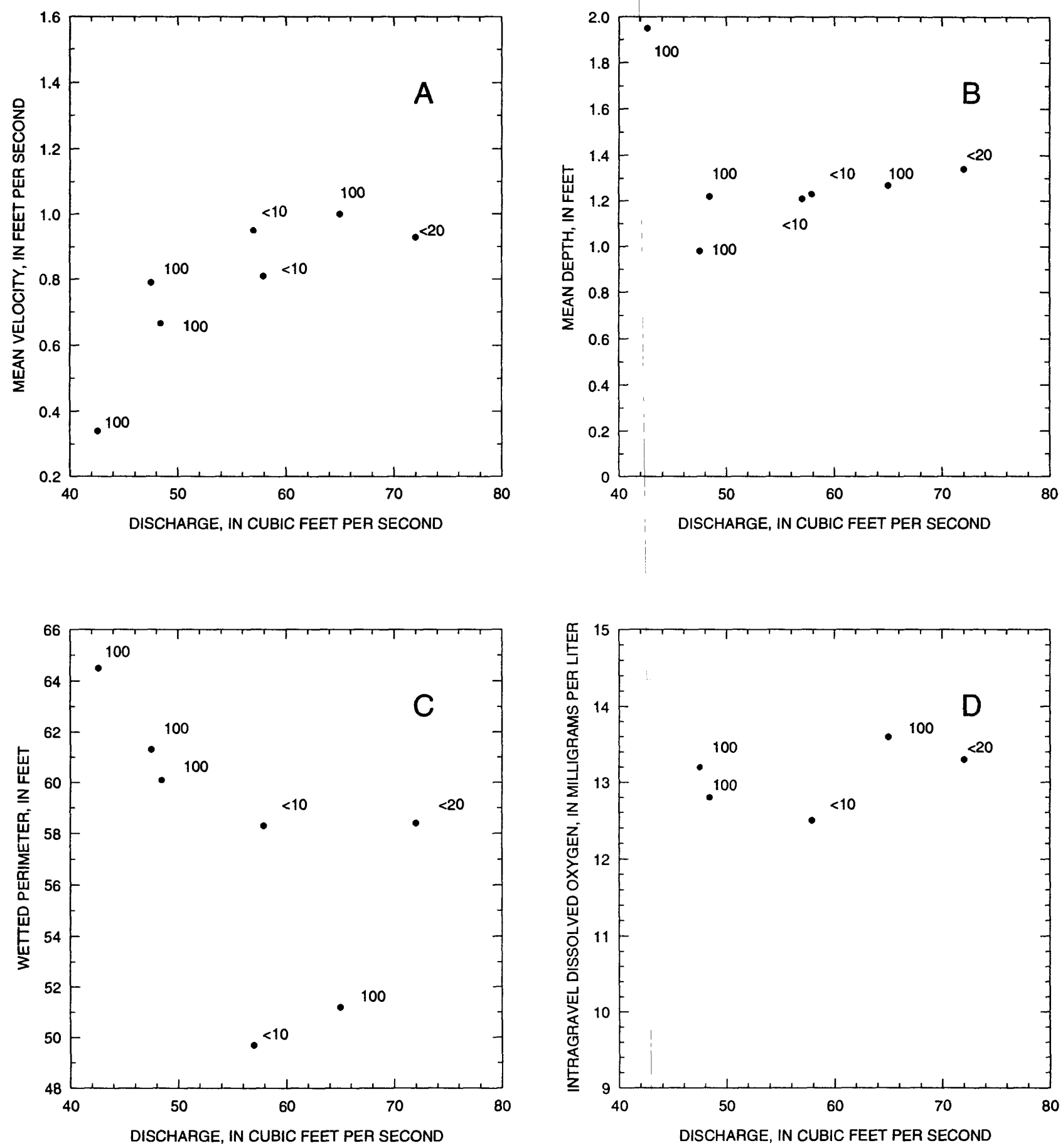

EXPLANATION

-100 data point and percent ice cover at time of measurement

Figure 9. Physical properties of Bradley River below Fish Camp transect. 

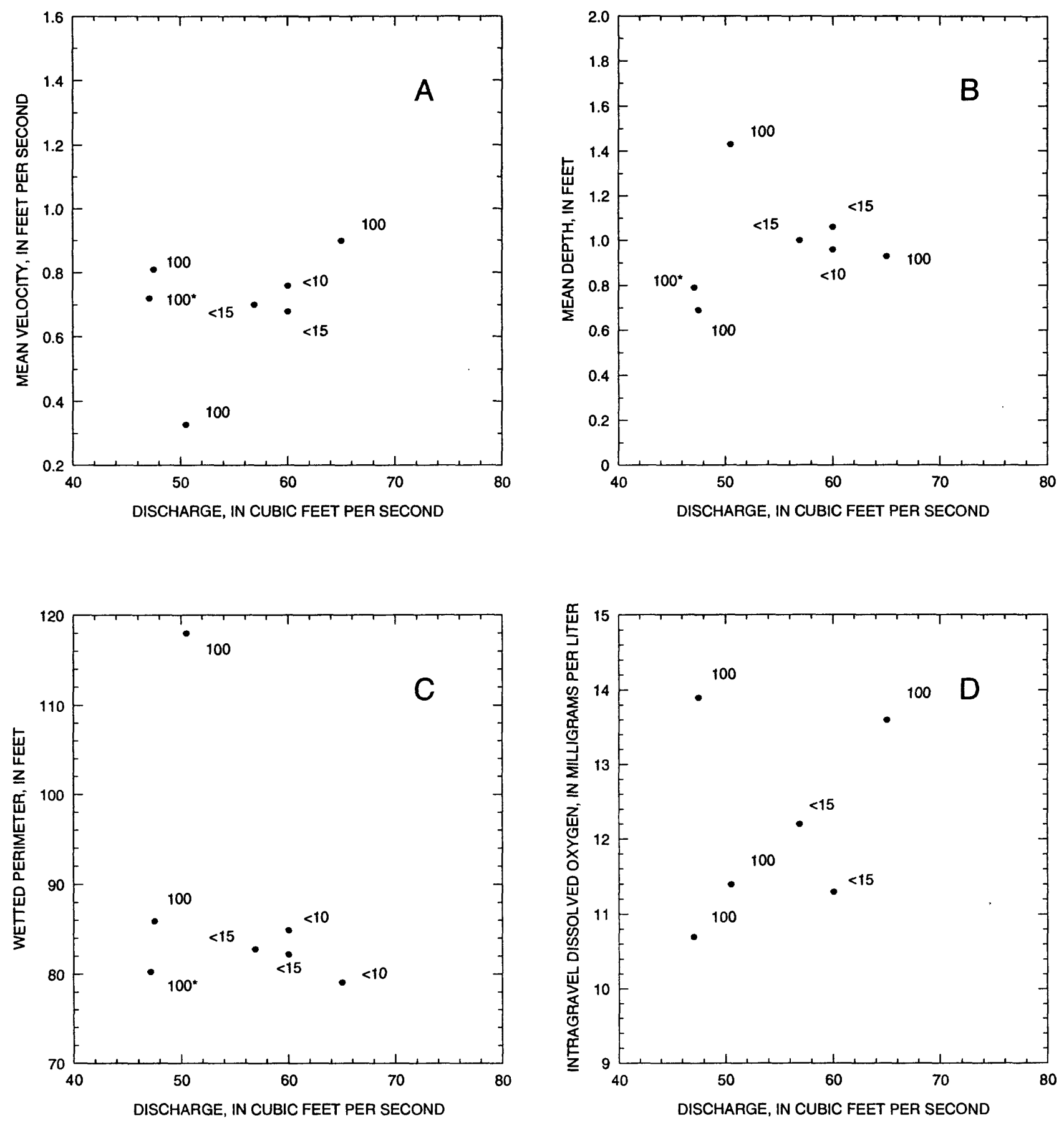

\section{EXPLANATION}

.100 data point and percent ice cover at time of measurement

Figure 10. Physical properties of Bradley River at Upper Riffle Reach transect. 

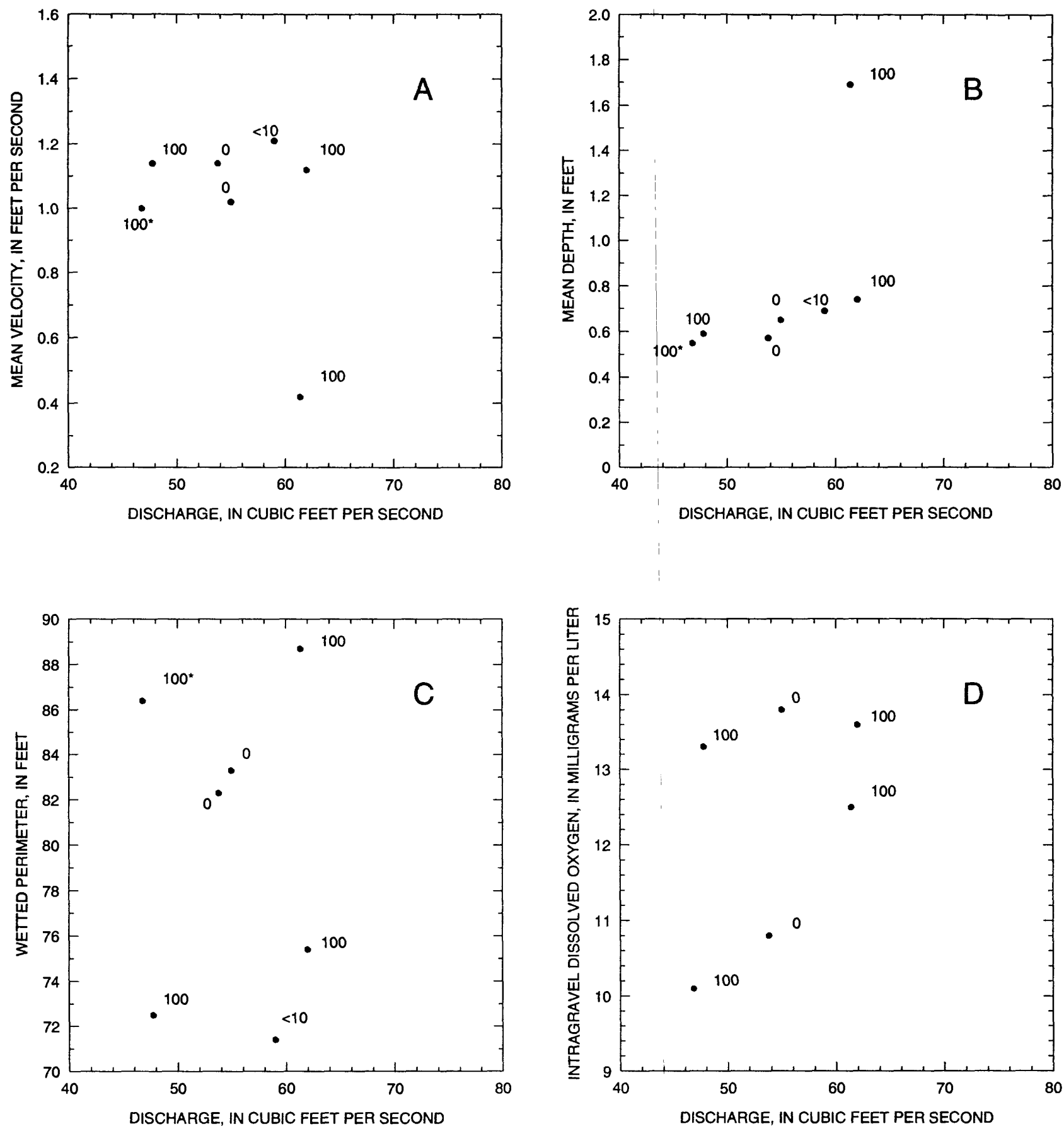

EXPLANATION

.100 data point and percent ice cover at time of measurement

Figure 11. Physical properties of Bradley River at Lower Riffle Reach transect. 

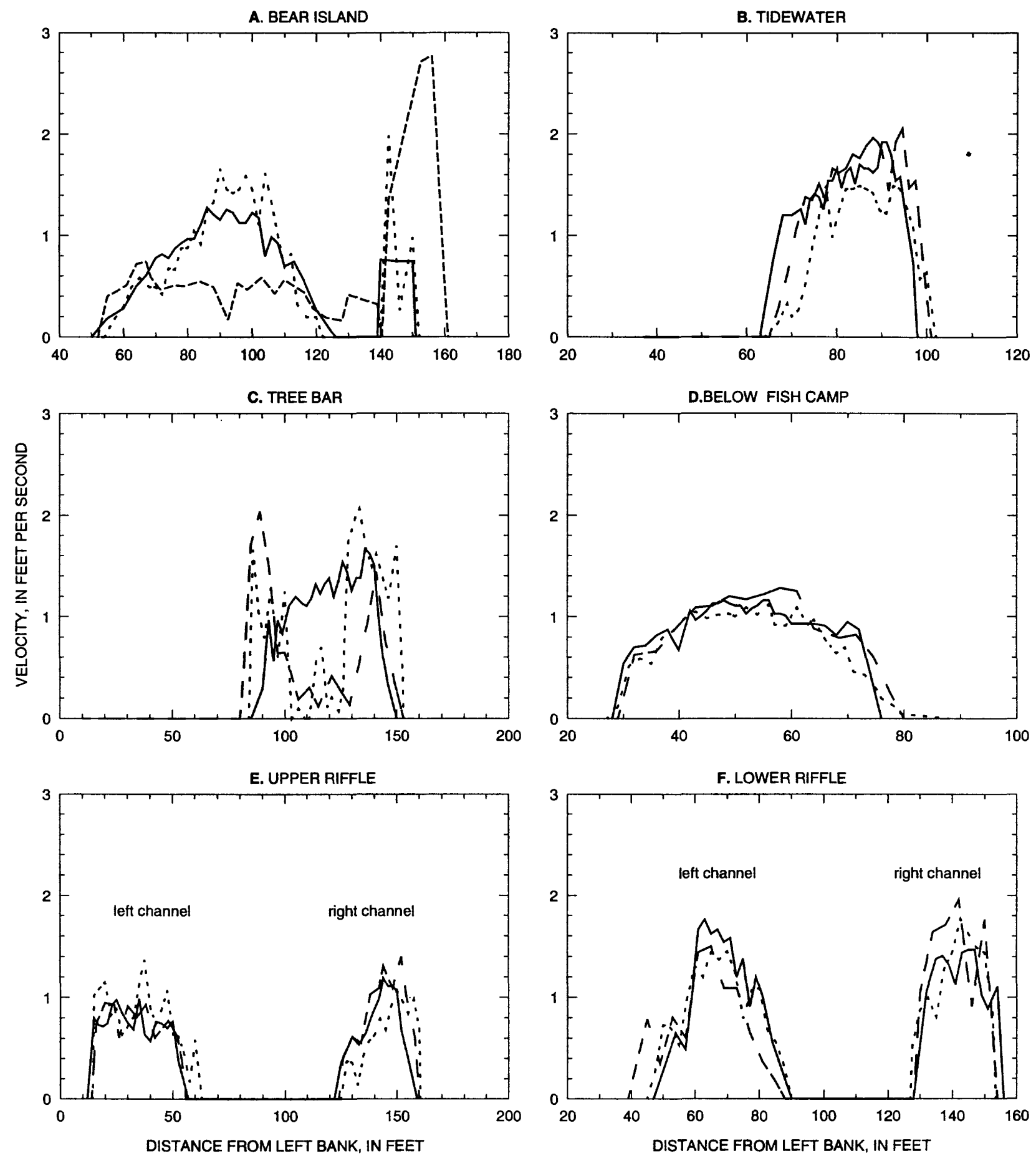

EXPLANATION

MARCH 1993, ice cover < 10 percent, discharge $57 \mathrm{ft}^{3} / \mathrm{s}$

- _ FEBRUARY 1994, 100 percent ice cover, discharge $66 \mathrm{ft}^{3} / \mathrm{s}$

FEBRUARY-MARCH 1995, 100 percent ice cover, discharge $52 \mathrm{ft}^{3} / \mathrm{s}$

Figure 12. Selected surface-water velocity distributions for the six transects in the lower Bradley River.

(Graphs are displayed in downstream order from A to F. See figure 3 for locations of transects.) 
Mean depths were higher when ice cover exceeded 80 percent than when ice cover was less than 30 percent for the Bear Island, Tidewater, and Tree Bar Reach transects (figs. 6B-8B). No apparent relation exists between ice cover and mean depth at the Below Fish Camp, Upper Riffle Reach, and Lower Riffle Reach transects (figs. 9B-11B). Mean depths did decrease with decreasing discharge, for similar ice conditions, for the Bear Island and Lower Riffle Reach transects. The relation between depth and discharge for similar ice conditions is ambiguous at the remaining transects, where each episode of ice formation caused a different and unique velocity distribution. Depth in the lower Bradley River does not appear to be a significant factor affecting salmon egg and alevin habitat, except possibly at Lower Riffle Reach. Shallow depths at Lower Riffle Reach may explain why pink salmon spawning has decreased in this area, but a more likely explanation is silt deposition (Morsell and Howard, 1995).

\section{Wetted Perimeter}

Wetted perimeter is defined for this report as the part of streambed within a transect that is wetted by surface water, and does not include the ice/water boundary. Prior to flow regulation in the lower Bradley River, wetted perimeter during summer spawning was much larger than that during egg and alevin development during the winter. As a result, most of the eggs deposited in the summer were dewatered and frozen during the winter, resulting in a high mortality rate (Woodward-Clyde, 1983, p. 47; Rickman, 1993, p. 12). The Woodward-Clyde instream flow study showed little difference in wetted perimeter (less than 15 percent) for flows between 30 and $50 \mathrm{ft}^{3} / \mathrm{s}$, but did not account for the expected increase caused by ice formation. Rundquist and Baldrige (1990, p. 82) suggested that incubation habitat would encompass 98.6 percent of the usable spawning habitat (assuming a discharge of $100 \mathrm{ft}^{3} / \mathrm{s}$ during spawning) at $40 \mathrm{ft}^{3} / \mathrm{s}$ and 97.2 percent at $30 \mathrm{ft}^{3} / \mathrm{s}$.

Wetted perimeter data for March 1993 to April 1994 have been reported previously (Rickman, 1995). Data for November 1994 through April 1995 are presented in appendixes 1 and 2. Wetted perimeter ranged from $35.6 \mathrm{ft}$ for the Tidewater transect (March 11, 1993, discharge $56 \mathrm{ft}^{3} / \mathrm{s}$, ice cover less than 10 percent; Rickman, 1995) to $118 \mathrm{ft}$ for the Upper Riffle Reach transect (January 12, 1995, discharge $50.5 \mathrm{ft}^{3} / \mathrm{s}, 100$ percent ice cover). From March 1993 to April 1995, the Tidewater transect had the least wetted perimeter variability (range 35.6 to $43.8 \mathrm{ft}$ ), probably because the channel is narrow and deep, with steep streambanks. Tree Bar and Upper Riffle reach transects had the greatest variability.

No apparent relation exists between percent ice cover and wetted perimeter for similar discharges (figs. 6C -11C). Ice sometimes freezes to the stream bottom along the streambanks, resulting in dry, frozen stream gravels. Other times, the ice may not freeze to the bottom, but instead it may cause a backwater condition to increase wetted perimeter, as was expected. Ice may also be bridged and have no effect on wetted perimeter.

Wetted perimeter does not appear to be a function of discharge for any given percent ice cover. Graphs of discharge plotted against wetted perimeter (figs. 6C-11C) show a wide scatter in the data with few or no trends. Discharges of $40 \mathrm{ft}^{3} / \mathrm{s}$ or les\$ will probably have little effect on wetted perimeter as shown by the data presented here and the Woodward-Clyde open-water instream flow study. 


\section{FIELD WATER-QUALITY DATA}

\section{Temperature}

Development rate, survival, size of hatched alevins, and the percentage of deformities are related to water temperature during incubation (Groot and Margolis, 1991, p. 156). Cold water is able to hold a higher concentration of dissolved oxygen than warm water, which is beneficial to salmon embryo development. Water that is too cold retards development. Severe icing of the streambed can cut off oxygen supplies to the intragravel water. The effect of temperature on the rate of development in salmonids has been well documented (Groot and Margolis, 1991, p. 159). Warmer temperatures result in faster development. Development rate is proportional to thermal input and expressed in degree-days Celsius, and varies widely among fish stocks. Hatching has been found to occur roughly 100 to 600 degree-days after fertilization, depending on stock. Stock differences between and within pink salmon populations permit adaptive adjustments in hatching and emergence timing to thermal characteristics of individual streams (Groot and Margolis, 1991, p. 159). The degree-days required for the lower Bradley River stock has not been investigated. In the lower Bradley River, eggs hatch in January, and the alevins remain in the gravel throughout the winter (John Morsell, Northern Ecological Services, oral commun., 1995). The exact time of emergence in the lower Bradley River is not known, but is suspected to be late March or early April. Analysis of intragravel-water temperature data for Bradley River near Tidewater from January 1 to April 1 gives 80, 106, and 99 degree-days for 1993, 1994, and 1995 water years, respectively. This is much lower than the 450 to 640 degree-days from hatching to emergence reported by Godin (1980, p. 741).

Intragravel-water temperature is generally warmer than surface-water temperature during the winter months in glaciated streams (Baldrige and Trihey, 1982). This is true for the lower Bradley River where the intragravel-water temperature is generally 0.5 to $1.0^{\circ} \mathrm{C}$ warmer than surface water (fig. 13). Surface-water temperatures measured at all the transects were within $0.5^{\circ} \mathrm{C}$ of each other on any given date (Rickman, 1995; appendix 2, table A2). Surface-water temperature was usually $0^{\circ} \mathrm{C}$ during periods of ice formation, regardless of discharge. Changes in surface and intragravelwater temperature were mostly a function of periodic warm rains and do not seem to be related to stream discharge. Neither surface- nor intragravel-water temperatures are expected to change at lesser discharges of 30 to $40 \mathrm{ft}^{3} / \mathrm{s}$ in the lower Bradley River.

\section{Dissolved Oxygen}

Adequate intragravel-water dissolved oxygen is necessary for salmon incubation success. The U.S. Environmental Protection Agency (USEPA, 1977) recommends a minimum of $5 \mathrm{mg} / \mathrm{L}$ dissolved oxygen to protect early life stages of cold water biota. Exchange of surface water with intragravel water is largely responsible for the maintenance of intragravel dissolved oxygen (Vaux, 1968). This exchange is controlled by depth and velocity of surface water, channel morphology, and streambed permeability (Wickett, 1954; Coble, 1961; Shumway and others, 1964; Chapman and McLeod, 1987).

Dissolved-oxygen data for the lower Bradley River, March 1993 to April 1994 have been previously reported (Rickman, 1995). Data for November 1994 to April 1995 are presented in appendix 2 (table A2). Concentrations of surface-water dissolved oxygen ranged from $13.0 \mathrm{mg} / \mathrm{L}$ at the 


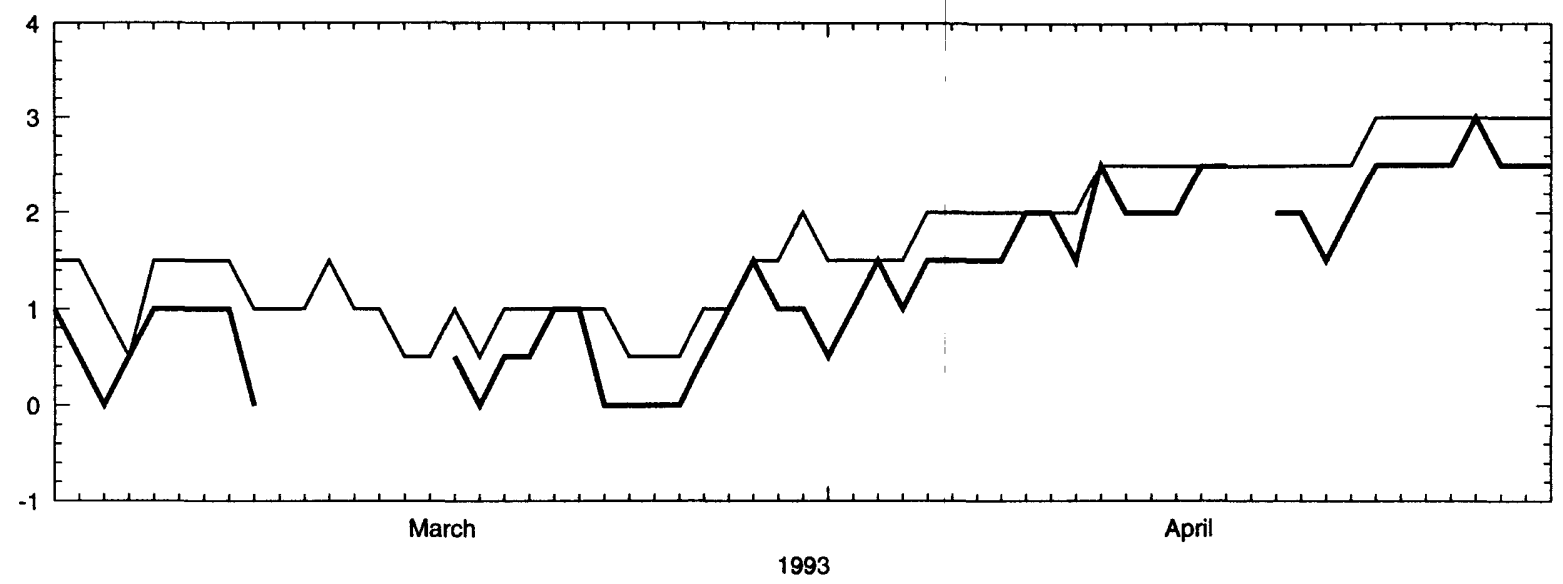

MARCH 1 TO APRIL 30, 1993

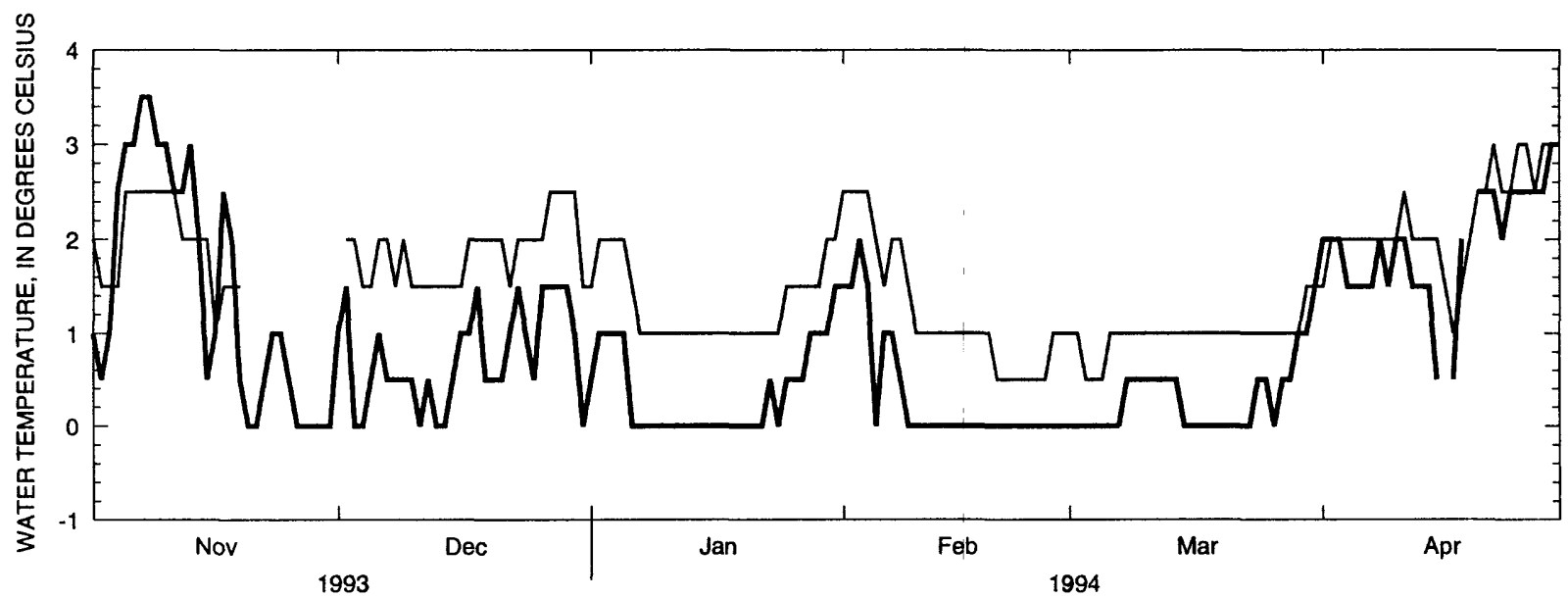

NOVEMBER 1, 1993 TO APRIL 30, 1994

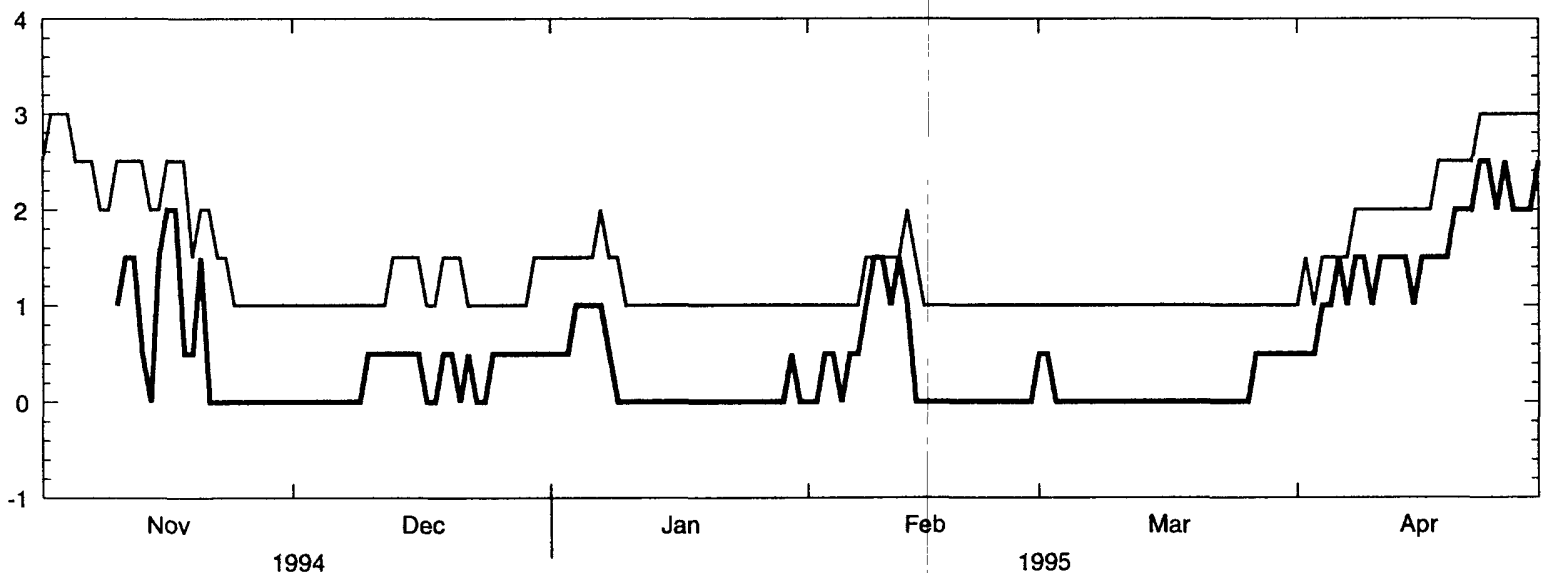

NOVEMBER 1, 1994 TO APRIL 30, 1995

EXPLANATION

Surface water

Intragravel water

Figure 13. Daily mean surface and intragravel water temperature of Bradley River near Tidewater. 
Upper Riffle Reach transect on April 5, 1995 (discharge $56.9 \mathrm{ft}^{3} / \mathrm{s}$, less than 10 percent ice cover, water temperature $1.0^{\circ} \mathrm{C}$ ) to $15.0 \mathrm{mg} / \mathrm{L}$ at the Below Fish Camp transect on December 1, 1994 (discharge approximately $48 \mathrm{ft}^{3} / \mathrm{s}, 100$ percent ice cover, water temperature $0.0^{\circ} \mathrm{C}$ ). Dissolved oxygen in surface water, expressed as percent saturation, ranged from 95 to 104 percent from March 1993 to April 1995. The high saturation is expected because water discharged from the fish-water bypass and tributary streams flows over numerous waterfalls before entering the lower Bradley River. Concentrations of intragravel dissolved oxygen ranged from $10.1 \mathrm{mg} / \mathrm{L}$ at the Lower Riffle Reach transect on November 30, 1994 (discharge $46.8 \mathrm{ft}^{3} / \mathrm{s}, 100$ percent ice cover, $0.90 \mathrm{ft}$ depth of water above streambed, surface-water velocity $1.2 \mathrm{ft} / \mathrm{s}$, intragravel-water temperature unknown) to $14.1 \mathrm{mg} / \mathrm{L}$ at the Bear Island transect on March 1, 1995 (discharge $53 \mathrm{ft}^{3} / \mathrm{s}, 30$ percent ice cover, $0.45 \mathrm{ft}$ depth of water above streambed, surface-water velocity $0.3 \mathrm{ft} / \mathrm{s}$, intragravel-water temperature unknown). All dissolved-oxygen concentrations were well above the concentration recommended by the USEPA.

Concentrations of surface-water and intragravel dissolved oxygen are plotted against distance downstream throughout the study area (fig. 14). Variance in the intragravel concentrations is much greater than in the surface-water concentrations. The reason for this is unknown.

No clear relations exist between percent ice cover, discharge, and intragravel dissolvedoxygen concentrations (figs. 6D-11D). In many cases, concentrations of intragravel dissolved oxygen were proportional to the percent ice cover, and inversely proportional to discharge. The reason for this is not clear, but may be a function of intragravel-water temperature. Observed intragravel and surface-water dissolved-oxygen concentrations were excellent for salmon egg, alevin, and fry development for stream-water discharges greater than $45 \mathrm{ft}^{3} / \mathrm{s}$ at all six transects. The data indicate that adequate dissolved-oxygen concentrations will occur at lesser flows, and that oxygen content is not the limiting factor for determining the minimum acceptable flow limit.

\section{Specific Conductance}

Intrusion of seawater into the lower Bradley River during periods of high tides is a function of river discharge (Woodward-Clyde, 1983, p. 48). Seawater intrusion is most likely to occur during the winter months when river discharge is lowest. Pink salmon often spawn in intertidal zones. Pink salmon eggs and alevins are tolerant to short exposures to seawater (Groot and Margolis, 1991, p. 156). The Woodward-Clyde study (1983, p. 55) showed that seawater intrusion would not be a factor within the study reach. Specific conductance may also be an indicator of ground-water contribution to stream discharge (Riggs, 1972, p. 12).

Specific conductance data for the lower Bradley River, March 1983 to April 1994 have been previously reported (Rickman, 1995). Data for November 1994 to April 1995 are presented in appendix 2 (table A2). From March 1993 to April 1995, specific conductance ranged from 60 to $76 \mu \mathrm{S} / \mathrm{cm}$ and did not vary significantly spatially or temporally. There was no indication of seawater intrusion from measurements taken immediately following high tides (March 1993, November to December 1994) which caused river water to back up in the study reach. Groundwater contributions to total river discharge cannot be determined from the specific conductance data. Specific conductance is not a factor for determining the effects of lesser flows on salmon incubation habitat in the lower Bradley River. 


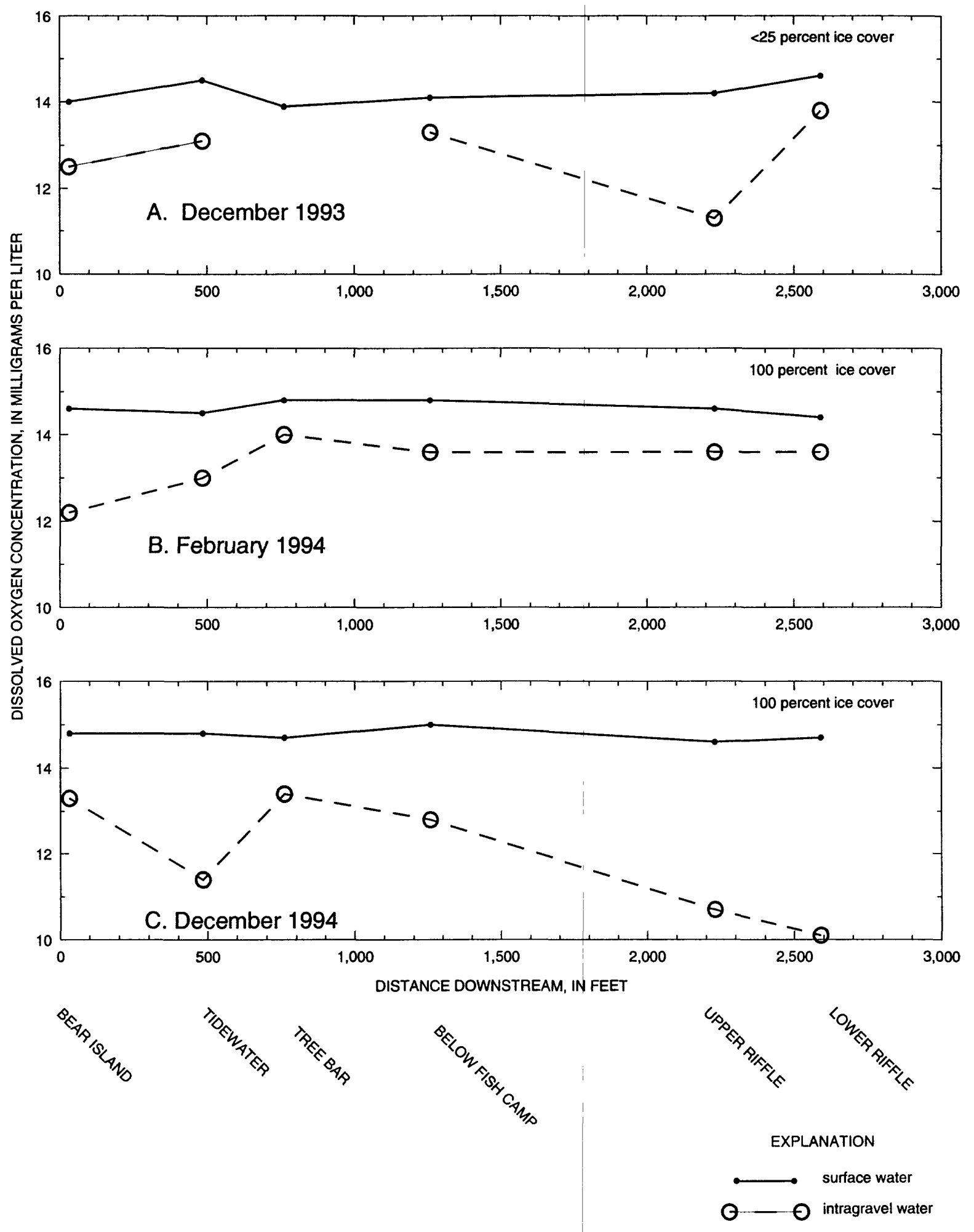

Figure 14. Dissolved oxygen concentrations at the six study transects, December 1993 to April 1995.

(Graphs are displayed in chronological order from A to F. See figure 3 for location of study sites.) 

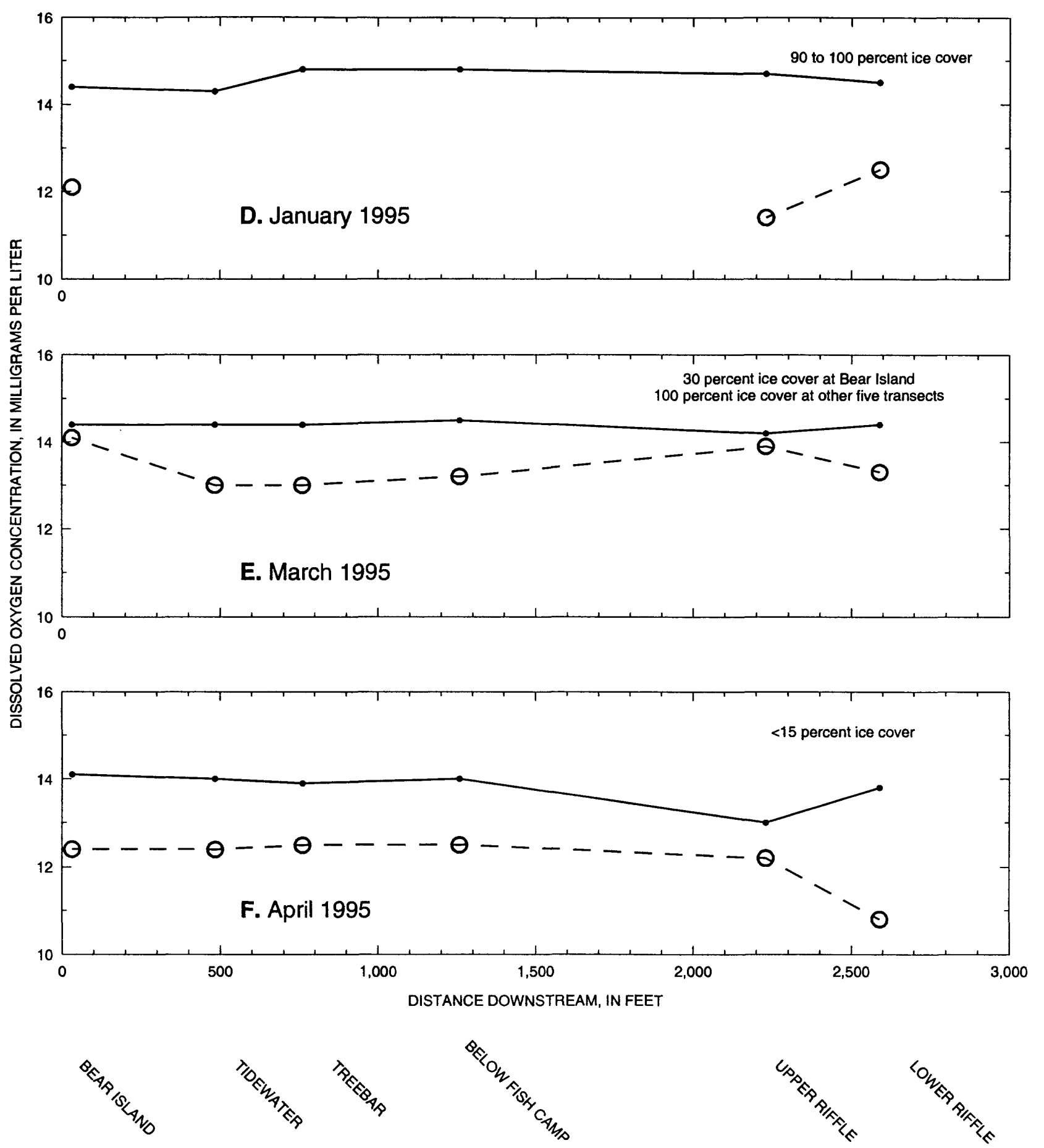

EXPLANATION

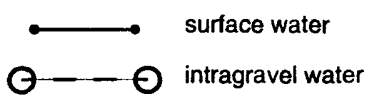

Figure 14. Continued. 


\section{STREAMBED STABILITY AND PERMEABILITY}

\section{Fine Sediment Deposition}

Measurement of fine sediment deposition in the lower Bradley River was beyond the scope of this study. However, field observations, stream discharge, and water-quality data have provided insight concerning the effects of sedimentation on Bradley River salmon incubation habitat. There are many definitions of particle size that constitutes "fine sediment" (Chapman and McLeod, 1987), but because particle size determination was not within the scope of this study, "fine sediment" will be used in a qualitative sense for purposes of discussion. Large quantities of fine sediment in salmon spawning beds can have severe adverse impacts on incubating salmon (Chapman and McLeod, 1987; Groot and Margolis, 1991). The largest effect of sediment deposition is reduced gravel permeability, which can reduce intragravel flow and decrease intragravel dissolved oxygen (Vaux, 1968; Wickett, 1954; Woods, 1980). Wickett found good survival in the presence of much surface sediment if adequate intragravel-water upwelling occurred. Large quantities of sediment can also hamper alevin movement and fry emergence.

Rundquist and others $(1985$, p. 86) noted deposition of fine sediment up to $0.3 \mathrm{ft}$ thick in dewatered areas during winter flows. Field observations at the Upper and Lower Riffle Reaches showed similar deposits in low-velocity areas within the wetted perimeter of the river following high tide cycles. Morsell and others (1993) noted that the Lower Riffle Reach had, at that time, been abandoned as a spawning area, while new spawning areas have opened up above Bear Island. This may be due to sediment deposition during high tides. Reduction of peak discharges following dam construction has lessened the ability of the river to flush fine sediment. Conversely, fine sediment load to the lower river from the upper Bradley River basin has probably decreased as a result of flow regulation. The North Fork and lower Middle Fork Bradley Rivers are clear-water non-glacial streams. They contribute a significant portion of the flow into the lower Bradley River, and this portion increases as the total flow decreases.

Fine sediment reduces gravel permeability, which reduces the interchange between surface and intragravel waters. A method to quantify this is to look at the percentage of dissolved-oxygen interchange between surface and intragravel-waters (Woods, 1980). Percentage of dissolved-oxygen interchange is defined using the equation:

$$
P=I / S \times 100
$$

where $P$ is interchange percentage, $I$ is intragravel dissolved-oxygen concentration, and $S$ is dissolved-oxygen concentration of surface water.

The interchange percentages at all six transects for each field visit are shown in figure 15 . Interchange percentages ranged from 68 at the Lower Riffle Reach transect (December 1, 1994) to 98 at Bear Island and Upper Riffle Reach transects (March 1, 1995). No consistent patterns of interchange percentage change from upstream to downstream are apparent within the study reach. Interchange percentages are high for all ice conditions and flows noted during this study, but additional data are needed to determine the effects of lesser flows. 

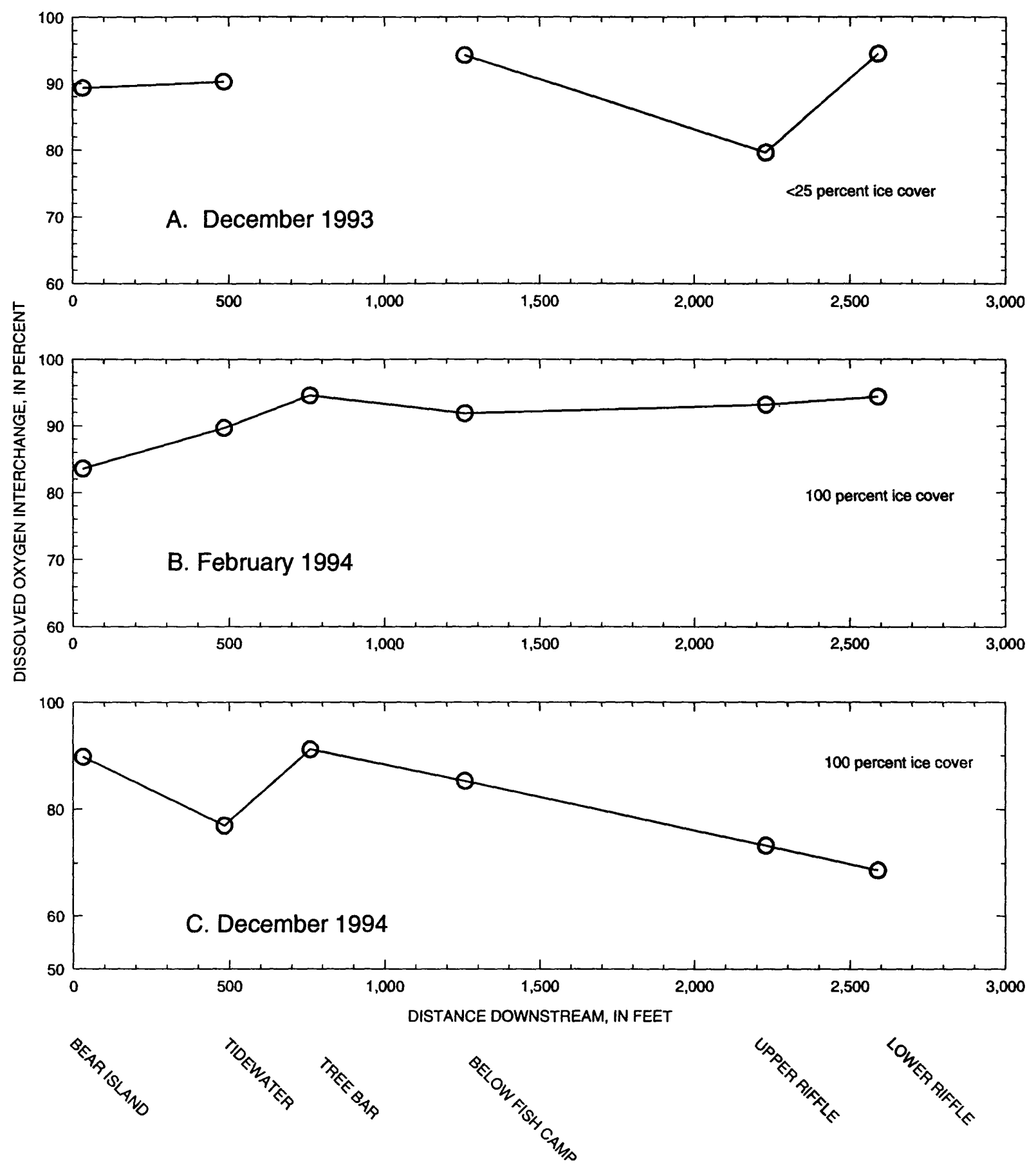

Figure 15. Dissolved oxygen percent interchange at the six study transects, December 1993 to April 1995.

(Graphs are displayed in chronological order from A to F. See figure 3 for location of study sites.) 
Shumway, D.L., Warren, C.E., and Doudoroff, P., 1964, Influence of oxygen concentrations and water movement on the growth of steelhead trout and coho salmon embryos: Transactions of the American Fisheries Society v. 93, p. 342-356.

Stevens, H.H., Jr., Ficke, J.F., and Smoot, G.F., 1975, Water temperature-Influential factors, field measurements, and data presentation: U.S. Geological Survey Techniques of Water-Resources Investigations, book 1, chap. D1, 65 p.

U.S. Environmental Protection Agency, 1977, Quality criteria for water, 1976: Washington, D.C., U.S. Government Printing Office, $256 \mathrm{p}$.

Vaux, W.G., 1968, Intragravel flow and interchange of water in a streambed: Fishery Bulletin, v. 66, no. 3, p. 479-489.

Wickett, W.P., 1954, The oxygen supply to salmon eggs in spawning beds: Journal of the Fisheries Research Board of Canada, v. 11, no. 6, p. 933-953.

Woods, P.F., 1980, Dissolved oxygen in intragravel water of three tributaries to Redwood Creek, Humboldt County, California: American Water Resources Association, Water Resources Bulletin, v. 16, no. 1, p. 105-111.

Woodward-Clyde Consultants, 1983, Bradley River instream flow studies: Anchorage, Alaska, 75 p. 


\section{APPENDIX 1}

Cross-section and velocity distribution of the lower Bradley River:
A. At Bear Island
B. Near Tidewater
C. At Tree Bar Reach
D. Below Fish Camp
E. At Upper Riffle Reach
F. At Lower Riffle Reach 


\section{BRADLEY RIVER AT BEAR ISLAND}

CROSS SECTION
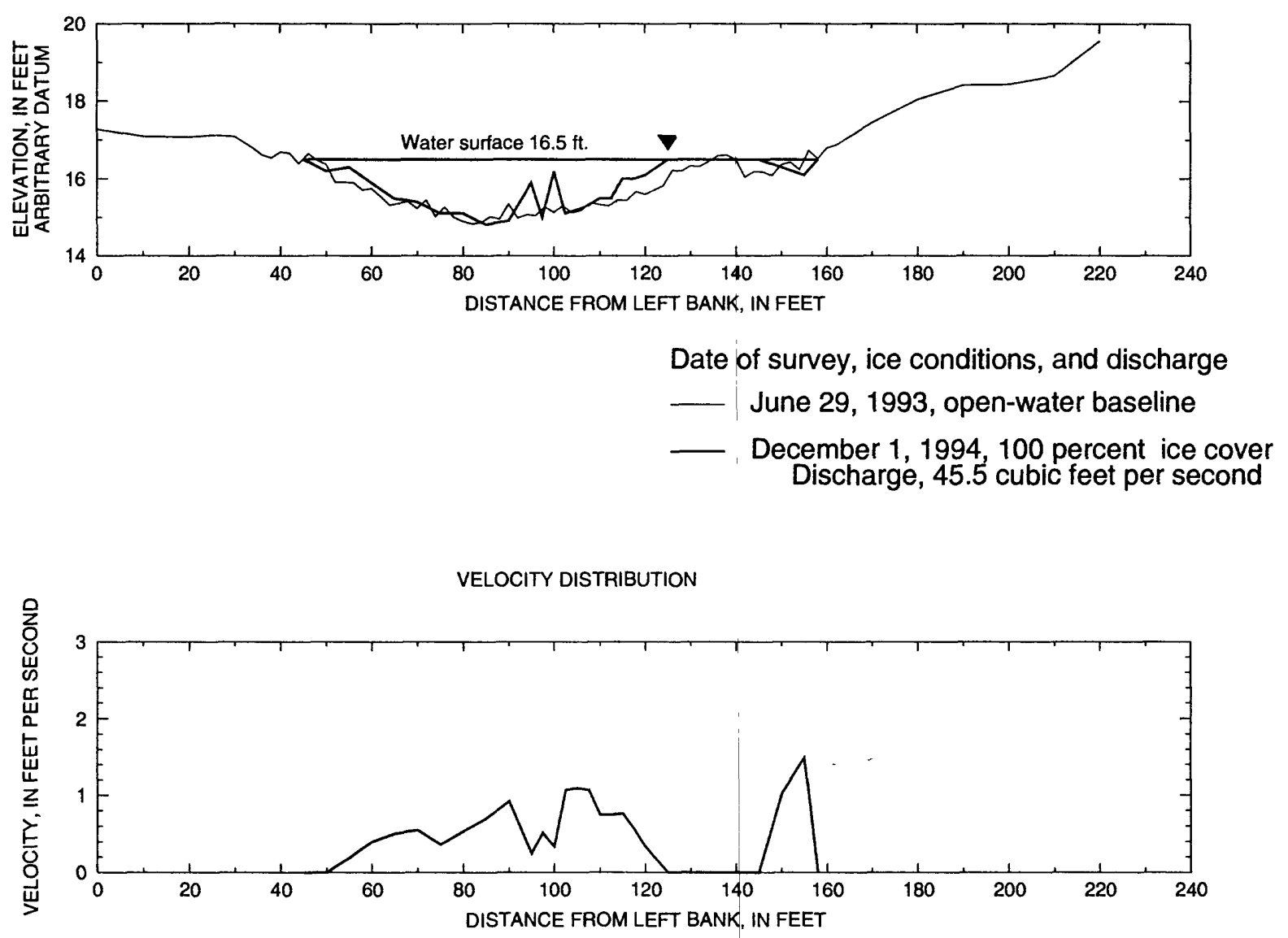

Date of survey, ice conditions, and discharge

December 1, 1994, 100 percent ice cover Discharge 45.5 cubic feet per second

Figure A. Cross-section and velocity distribution of the lower Bradley River at Bear Island (see figure 3 for transect location) 
BRADLEY RIVER AT BEAR ISLAND

CROSS SECTION

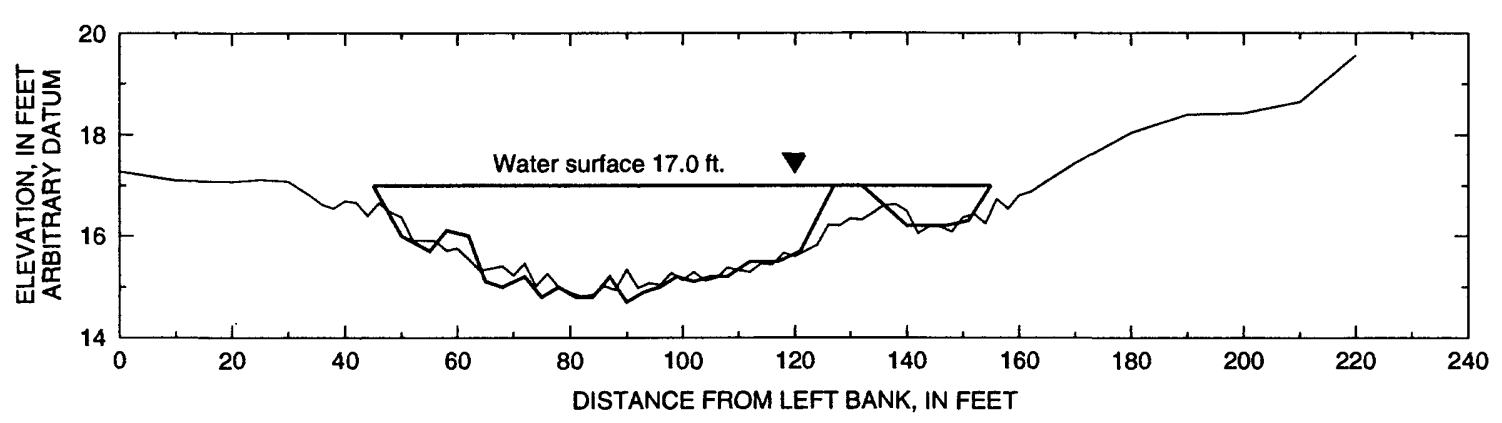

Date of survey, ice conditions, and discharge

_ June 29, 1993, open-water baseline

- January $11,1995,80$ percent ice cover Discharge $=62.7$ cubic feet per second

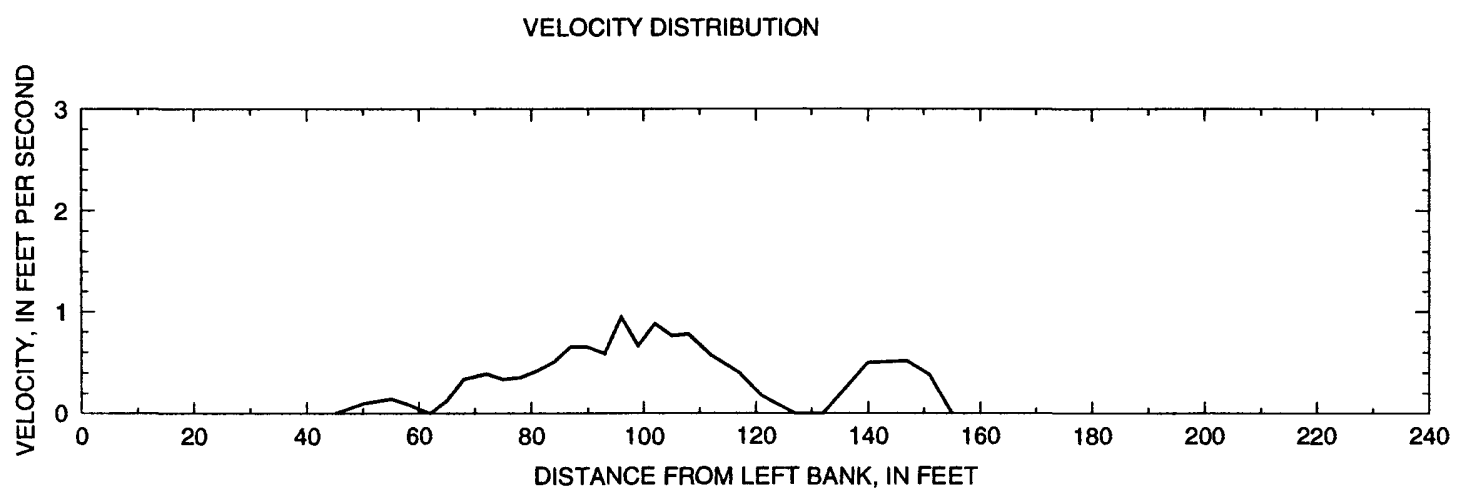

Date of survey, ice conditions, and discharge January $11,1995,80$ percent ice cover Discharge $=62.7$ cubic feet per second

Figure A. Continued. 


\section{BRADLEY RIVER AT BEAR ISLAND}

CROSS SECTION

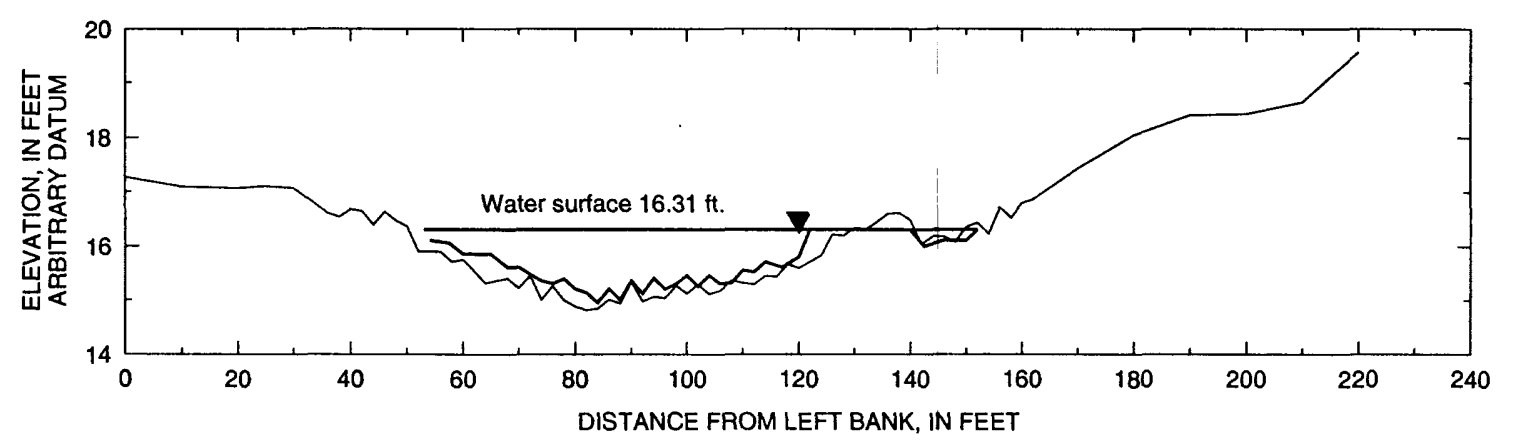

Date of survey, ice conditions, and discharge

__ June 29, 1993, open-water baseline

- March 1, 1995, 30 percent ice cover

Discharge, 53.3 cubic feet per second

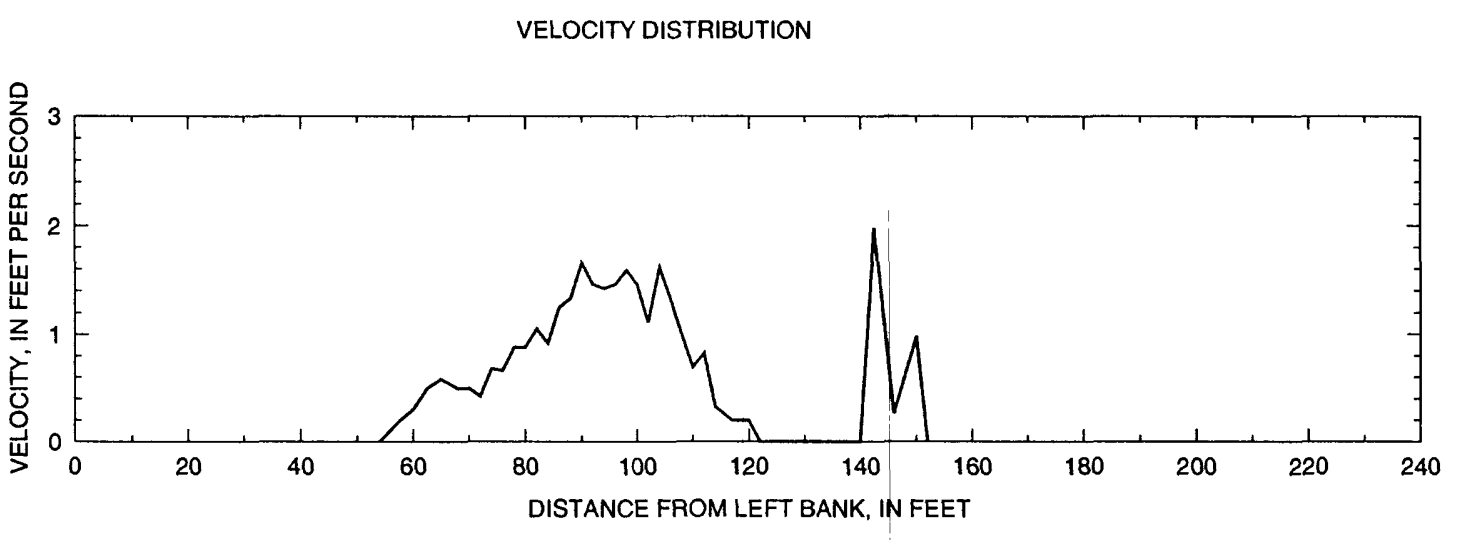

Date of survey, ice conditions, and discharge

_ March 1, 1995, 30 percent ice cover Discharge, 53.3 cubic feet per second

Figure A. Continued. 
BRADLEY RIVER AT BEAR ISLAND

CROSS SECTION

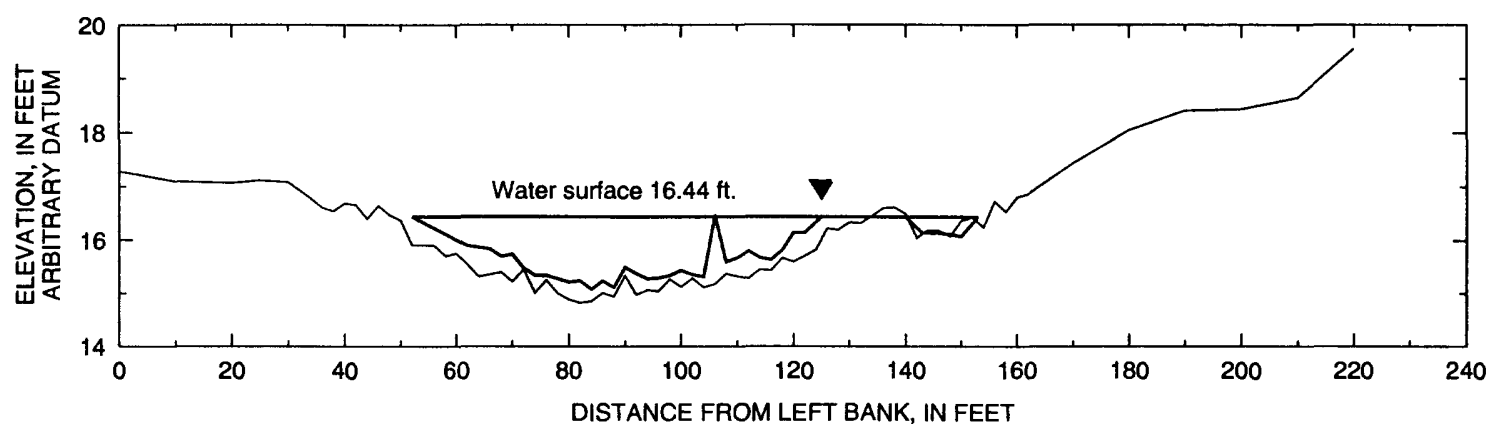

Date of survey, ice conditions, and discharge

__ June 29, 1993, open-water baseline

_- April 5, 1995, minor shore ice

Discharge, 56.7 cubic feet per second

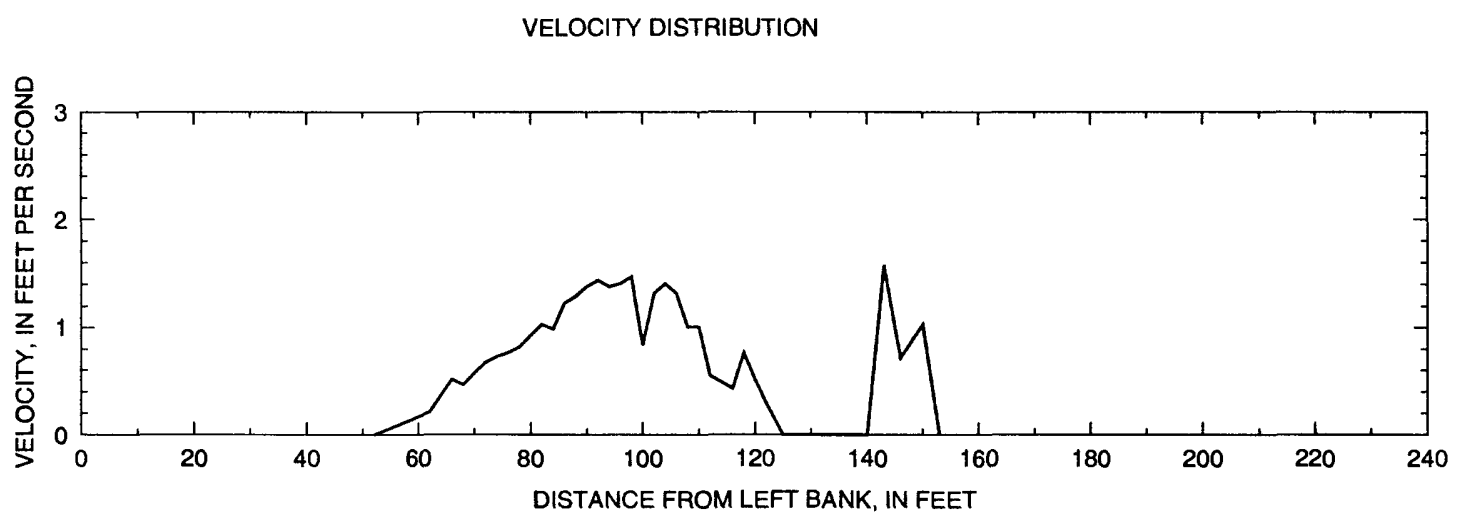

Date of survey, ice conditions, and discharge

April 5, 1995, minor shore ice

Discharge, 56.7 cubic feet per second

Figure A. Continued. 


\section{BRADLEY RIVER NEAR TIDEWATER}

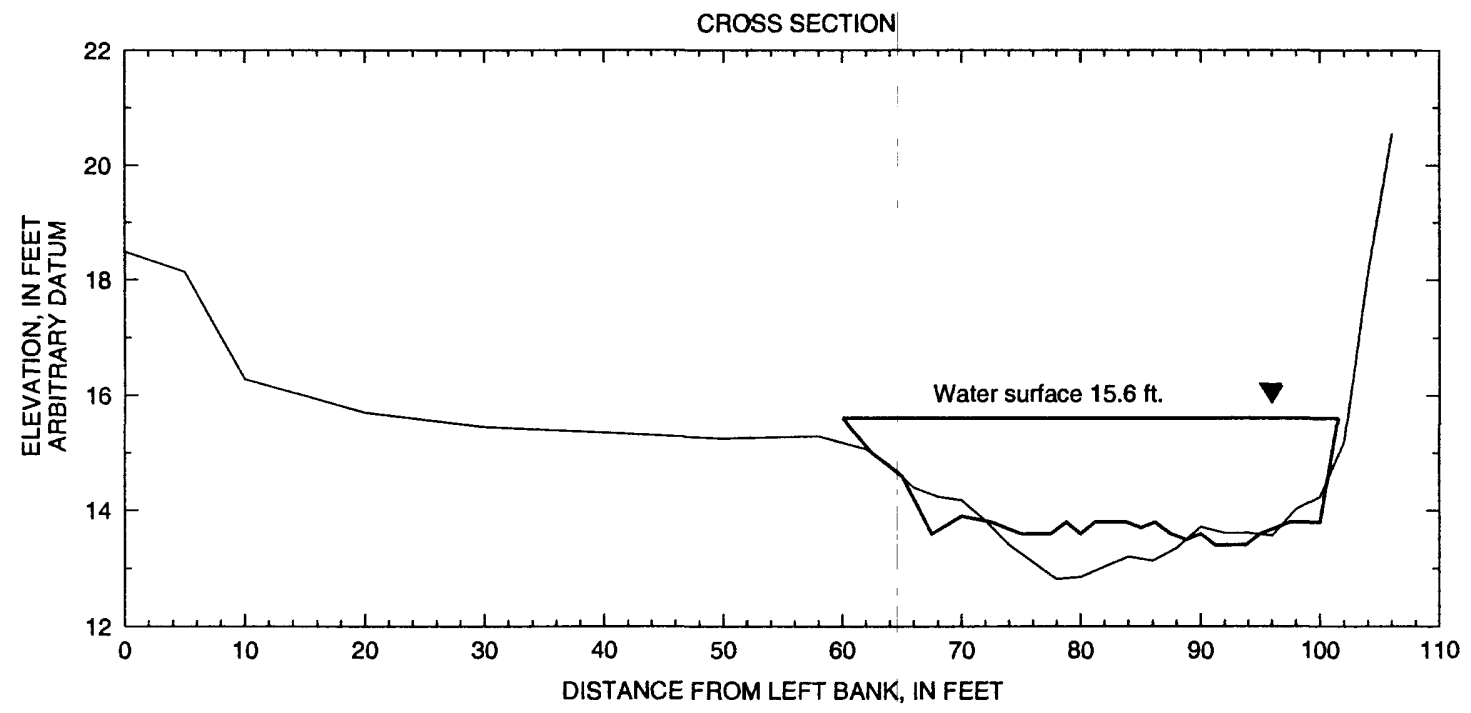

Date of survey, ice conditions, and discharge

— June 29, 1993, open-water baseline

- December 1, 1994, 100 percent ice cover

Discharge, 55.2 cubic feet per second

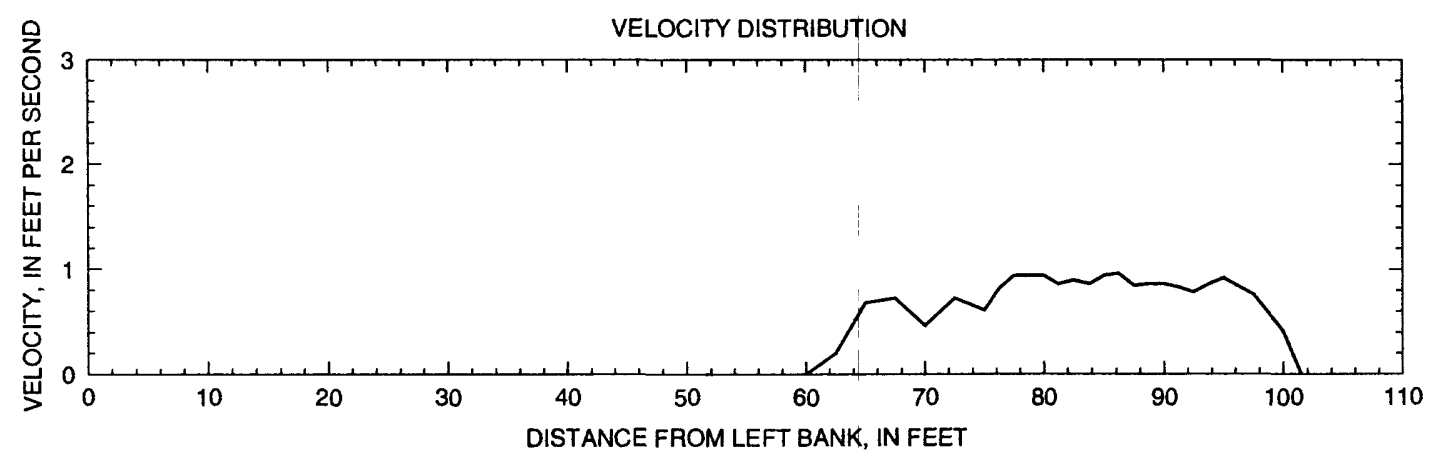

Date of survey, ice conditions, and discharge

December 1, 1994, 100percent ice cover Discharge, 55.2 cubic feet per second

Figure B. Cross section and velocity distribution of the lower Bradley River near Tidewater (see figure 3 for transect location) 


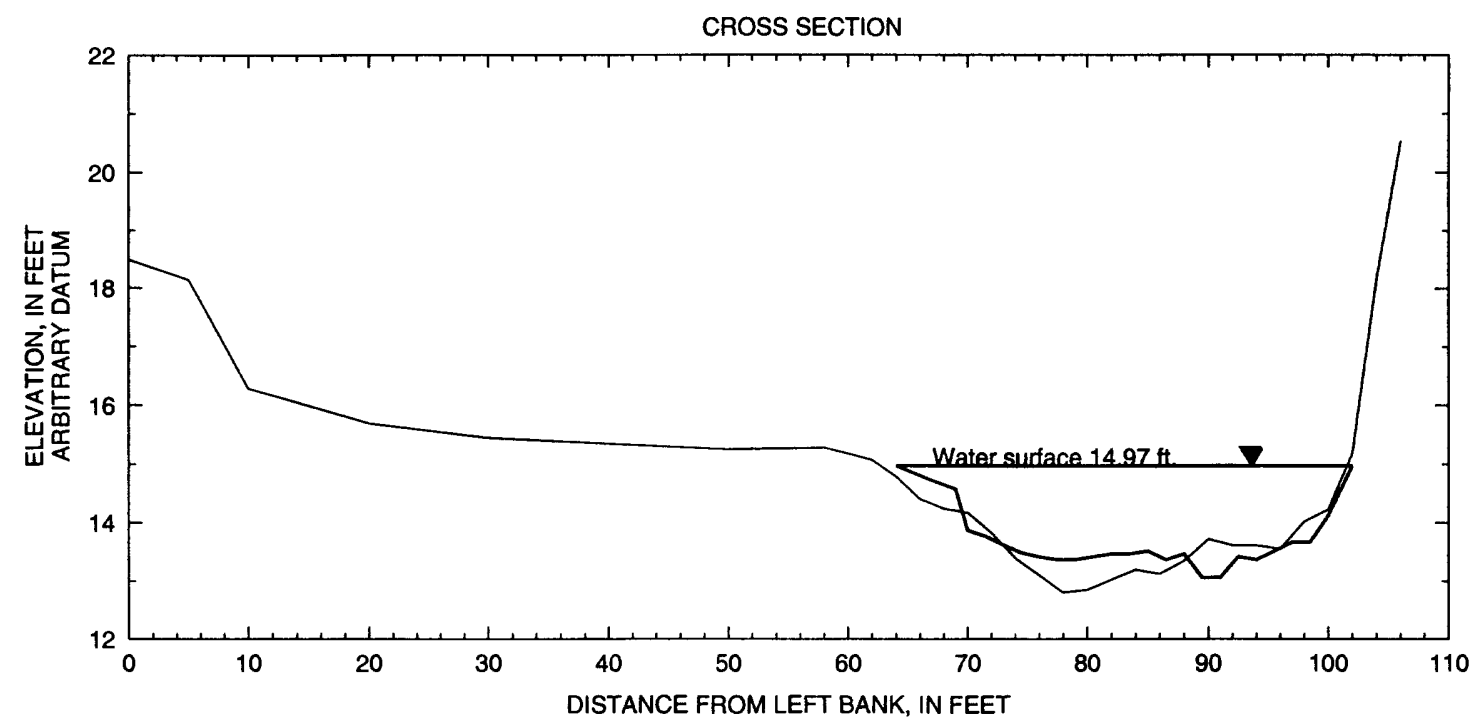

Date of survey, ice conditions, and discharge

_ June 29, 1993, open-water baseline

— March 1, 1995, 40 percent ice cover

Discharge, 52.5 cubic feet per second

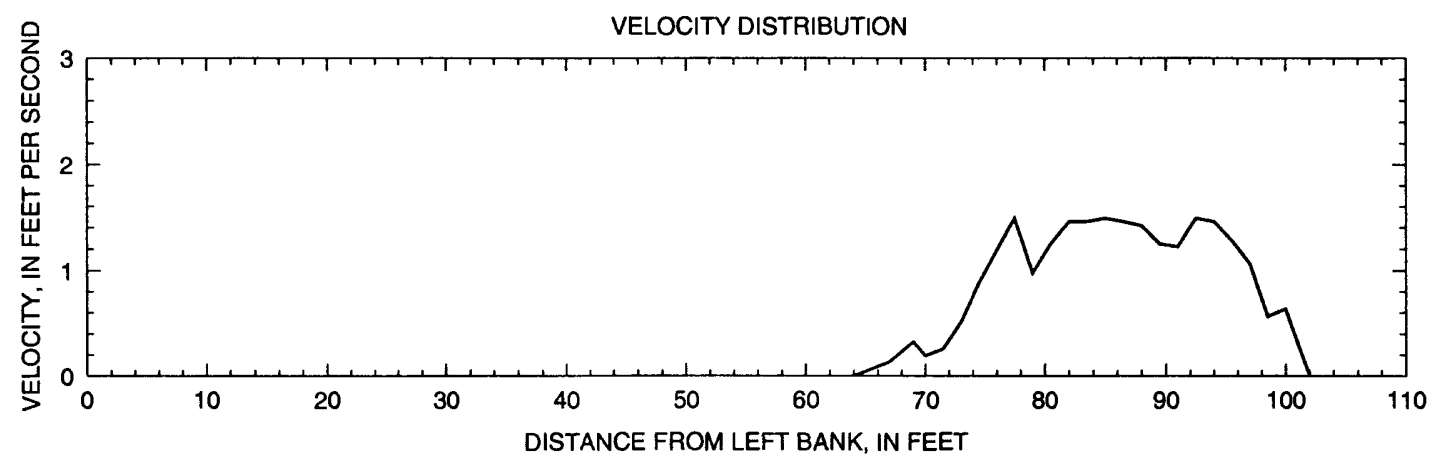

Date of survey, ice conditions, and discharge

March 1, 1995, 40 percent ice cover Discharge, 52.5 cubic feet per second

Figure B. Continued. 


\section{BRADLEY RIVER NEAR TIDEWATER}

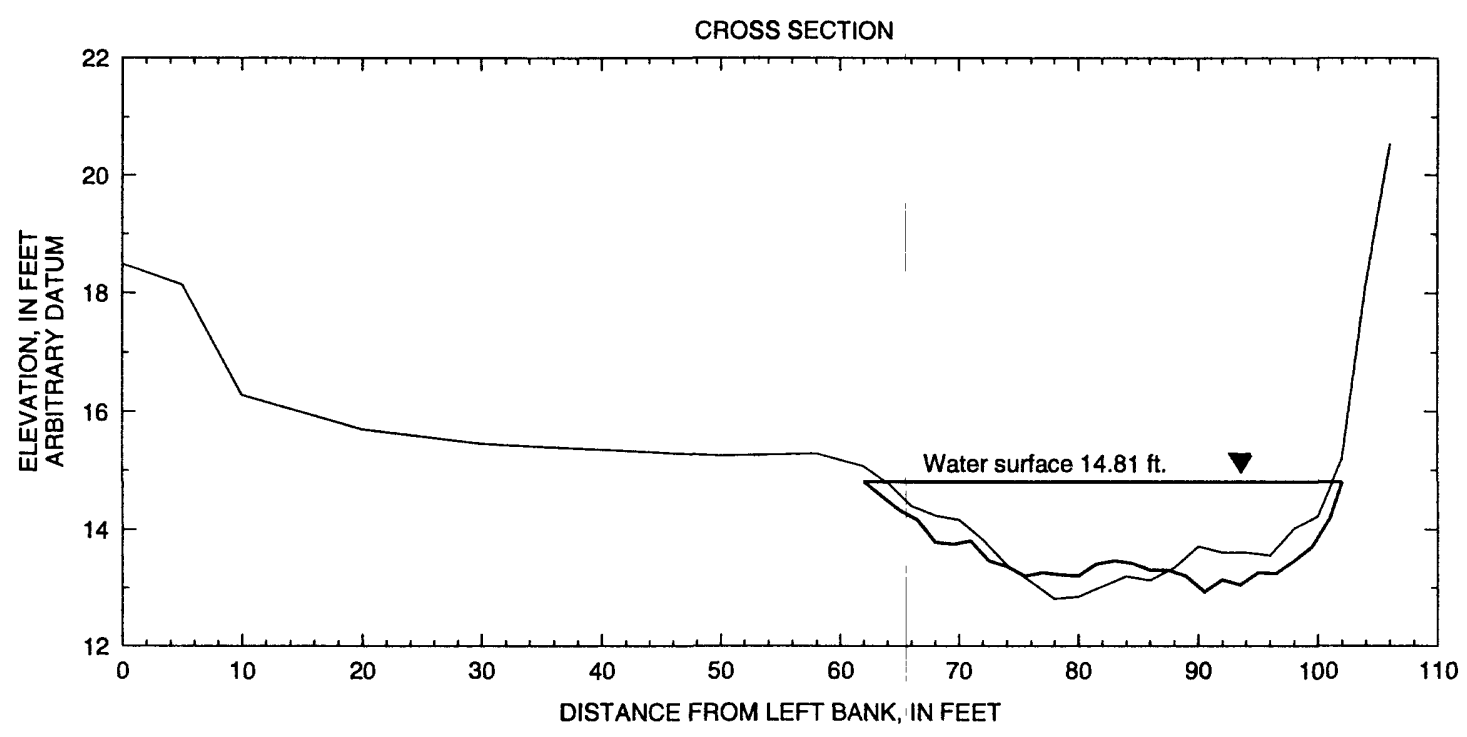

Date of survey, ice conditions, and discharge

__. June 29, 1993, open-water baseline

_ April 5, 1995, no ice

Discharge, 57.1 cubic feet per second

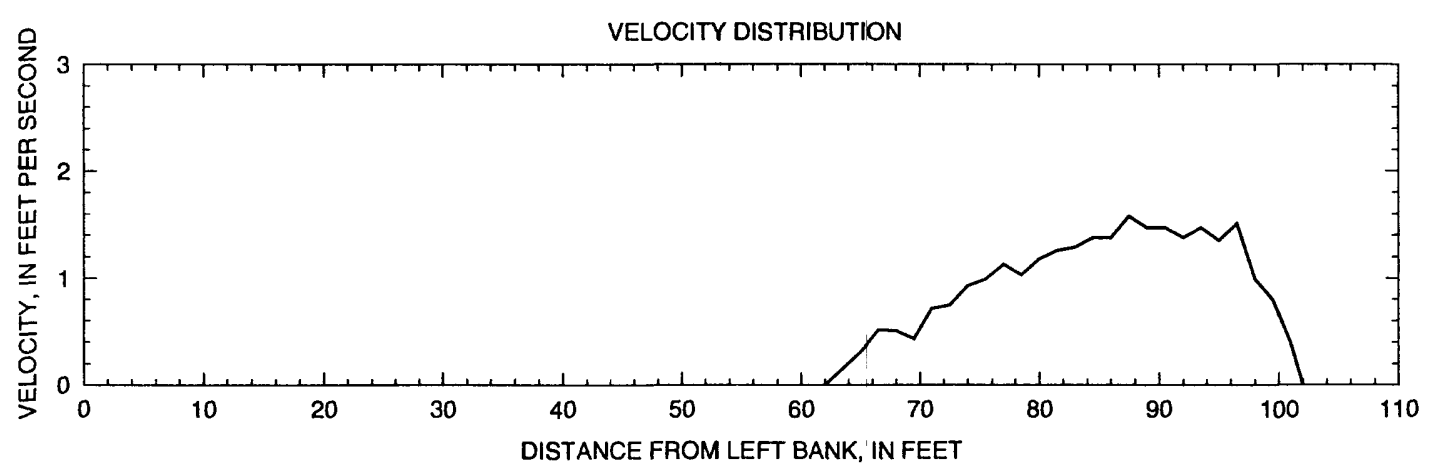

Date of survey, ice conditions, and discharge

April 5, 1995, no ice

Discharge, 57.1 cubic feet per second

Figure B. Continued. 
BRADLEY RIVER AT TREE BAR REACH

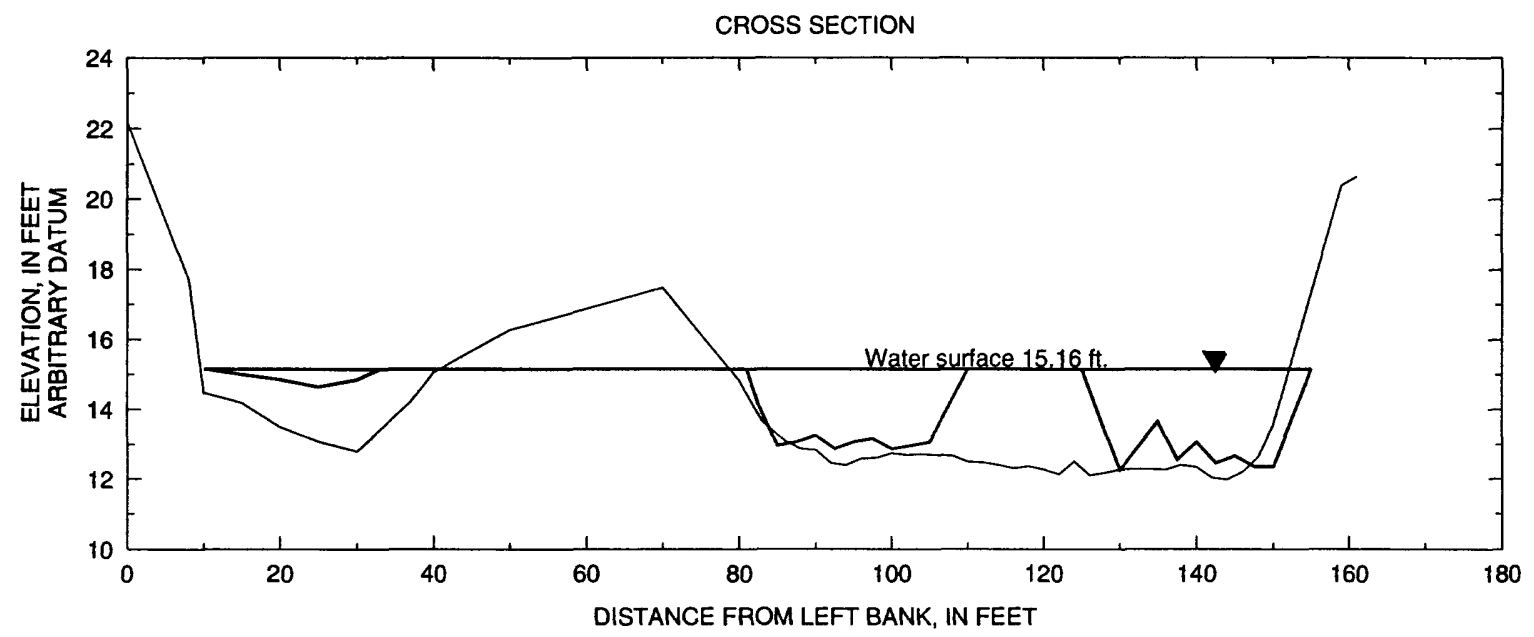

Date of survey, ice conditions, and discharge

_ June 29, 1993, open-water baseline

_ November 30, 1994, 100 percent ice cover

Discharge, 51.8 cubic feet per second

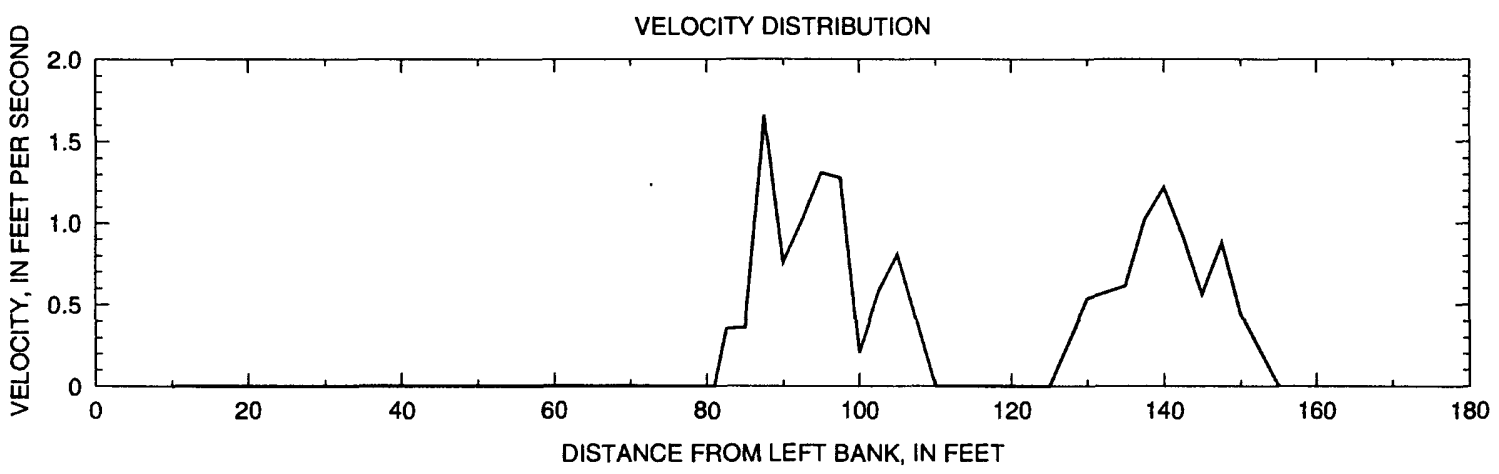

Date of survey, ice conditions, and discharge

November 30, 1994, 100 percent ice cover Discharge, 51.8 cubic feet per second

Figure C. Cross section and velocity distribution of the lower Bradley River at Tree Bar Reach (see figure 3 for transect location) 


\section{BRADLEY RIVER AT TREE BAR REACH}

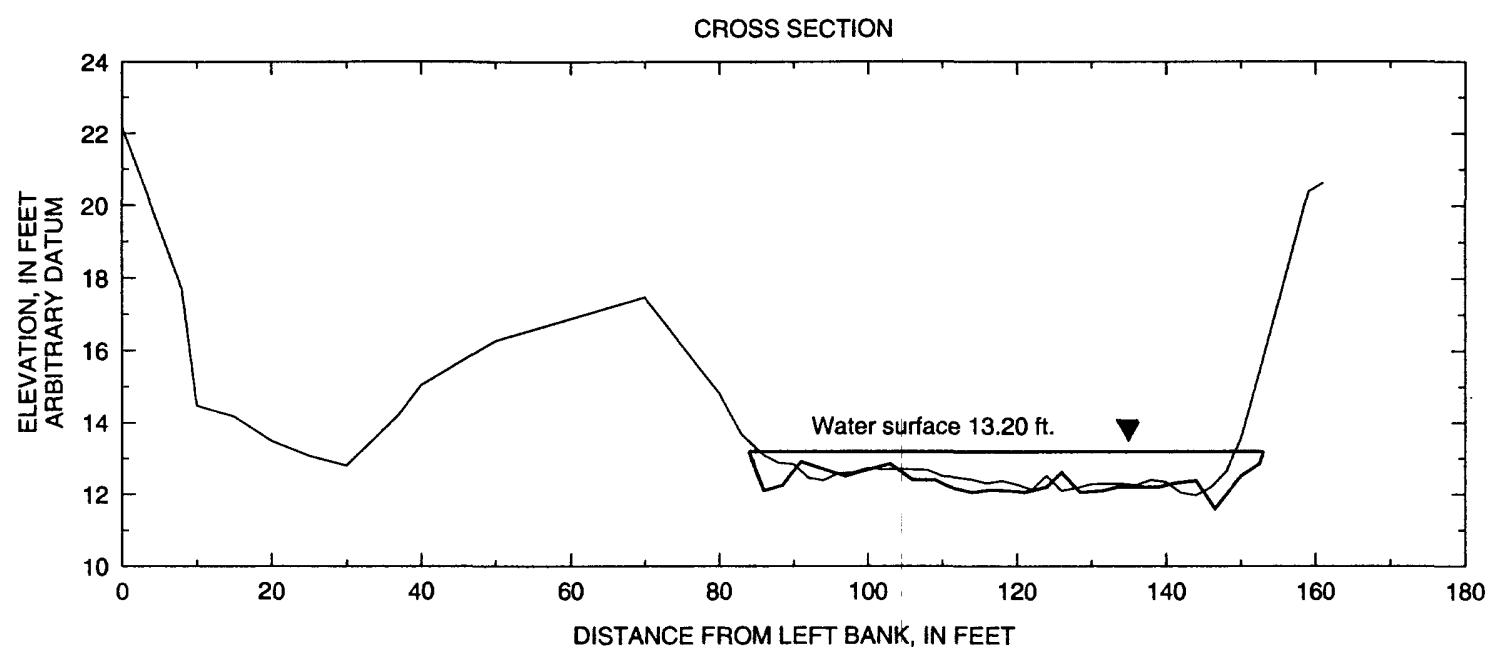

Date of survey, ice conditions, and discharge

_ June 29, 1993, open-water baseline

- February 28, 1995, 100 percent ice cover Discharge, 56.5 cubic feet per second

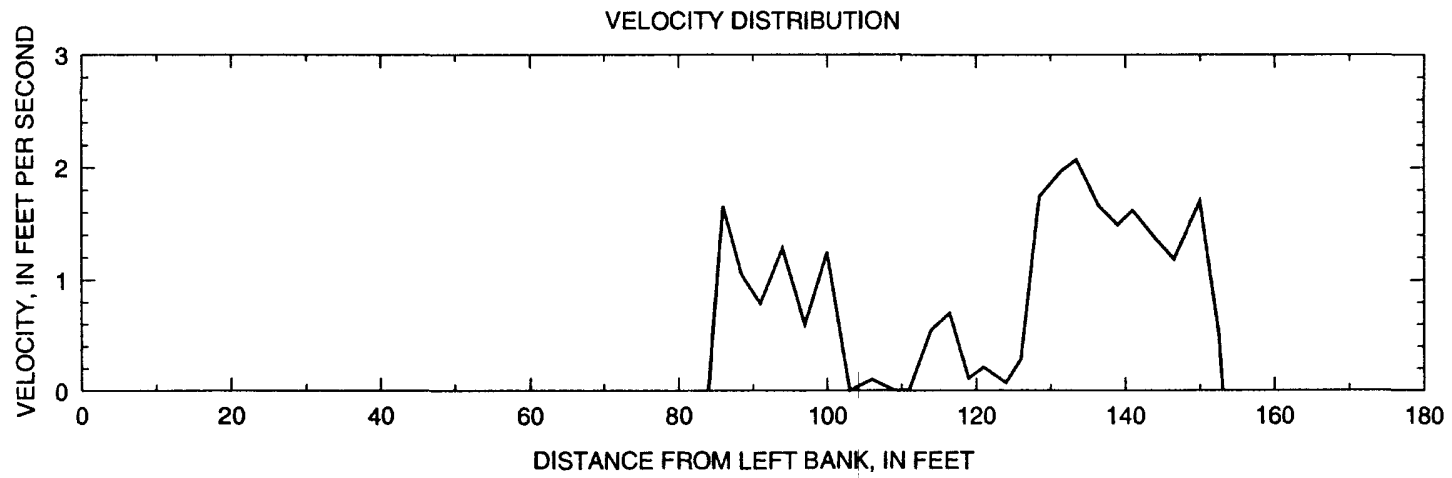

Date of survey, ice conditions, and discharge

February 28, 1995, 100 percent ice cover Discharge, 56.5 cubic feet per second

Figure C. Continued. 
BRADLEY RIVER AT TREE BAR REACH

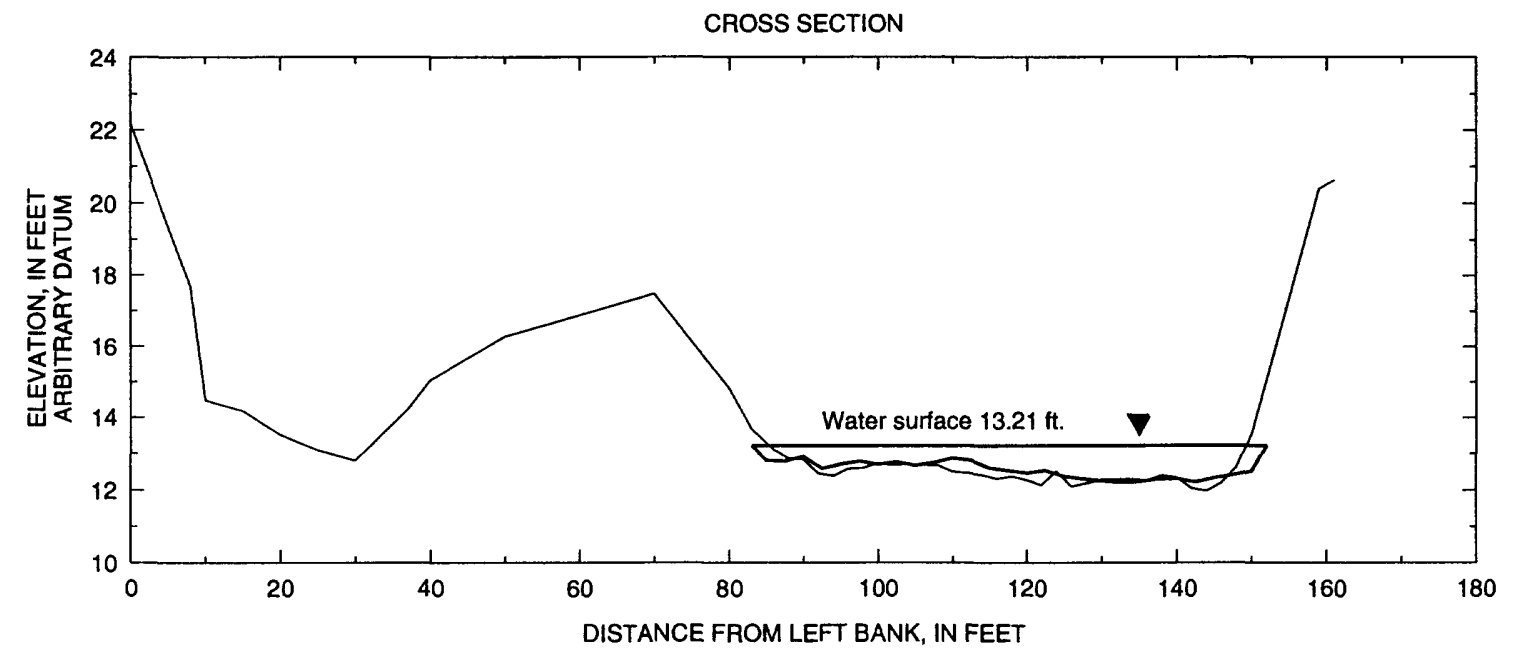

Date of survey, ice conditions, and discharge

_ June 29, 1993, open-water baseline

_ April 4, 1995, minor shore ice

Discharge, 55.3 cubic feet per second

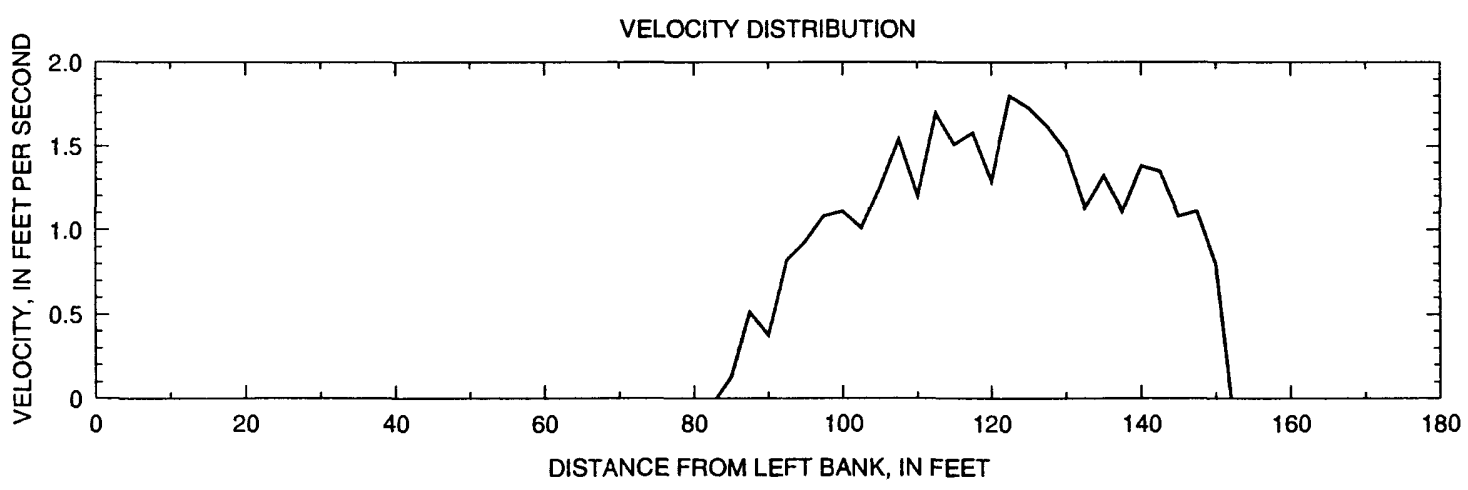

Date of survey, ice conditions, and discharge

April 4, 1995, minor shore ice Discharge, 55.3 cubic feet per second

Figure C. Continued. 


\section{BRADLEY RIVER BELOW FISH CAMP}

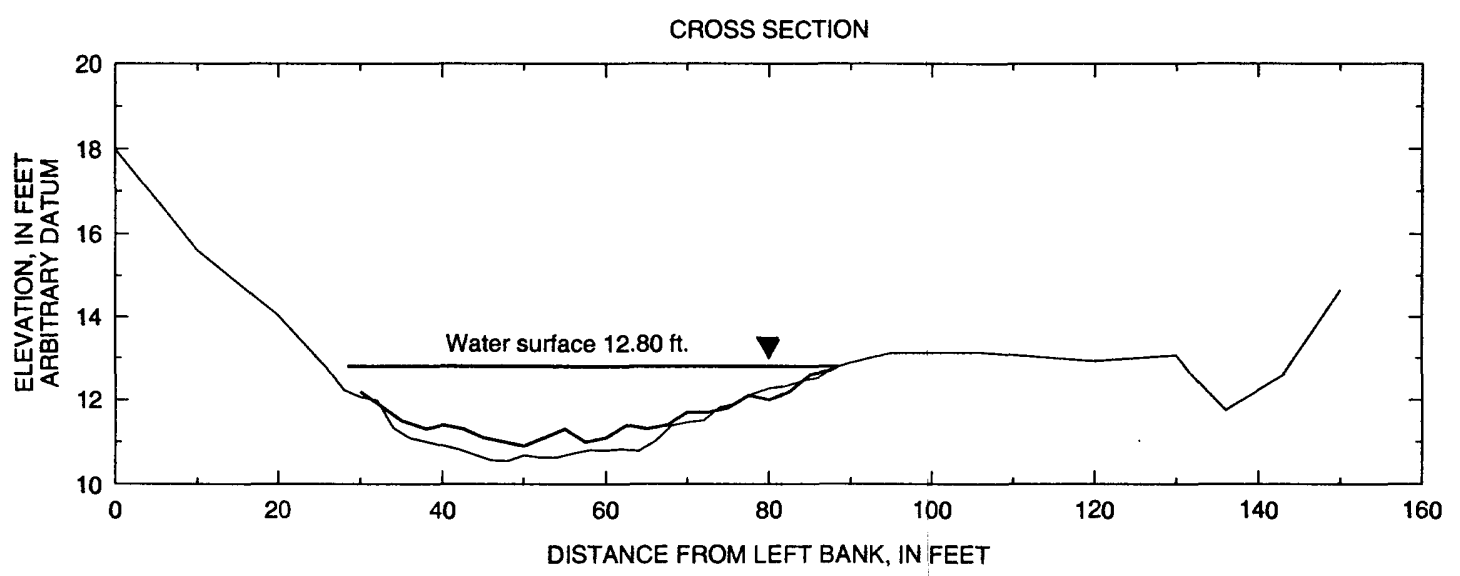

Date of survey, ice conditions, and discharge

_ June 29, 1993, open-water baseline

- November 29, 1994, 100 percent ice cover

Discharge, 48.4 cubic feet per second

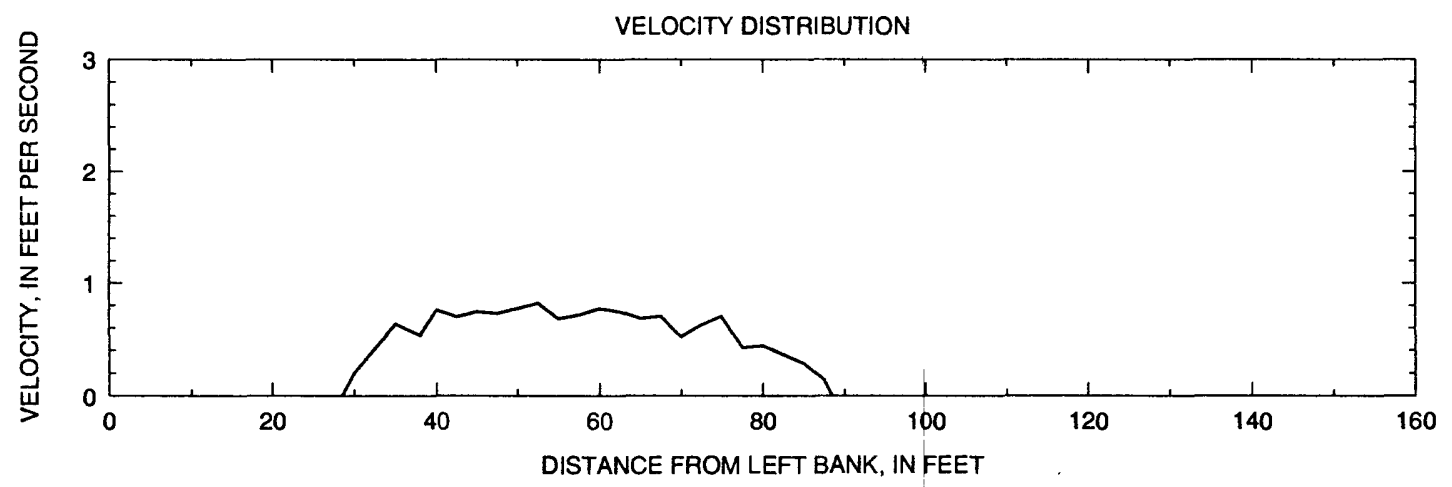

Date of survey, ice conditions, and discharge

November 29, 1994, 100 percent ice cover

Discharge, 48.4 cubic feet per second

Figure D. Cross section and velocity distribution of the lower Bradley River below Fish Camp (see figure 3 for transect location) 


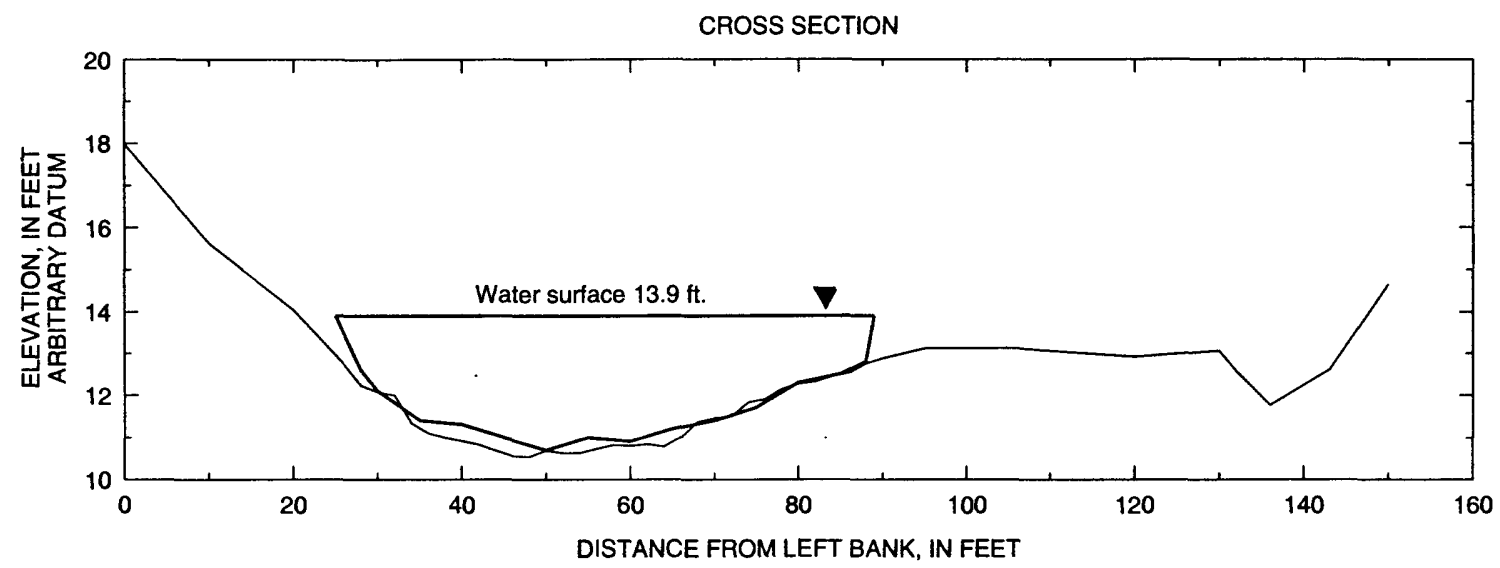

Date of survey, ice conditions, and discharge

__ June 29, 1993, open-water baseline January $12,1995,100$ percent ice cover Discharge, 42.6 cubic feet per second

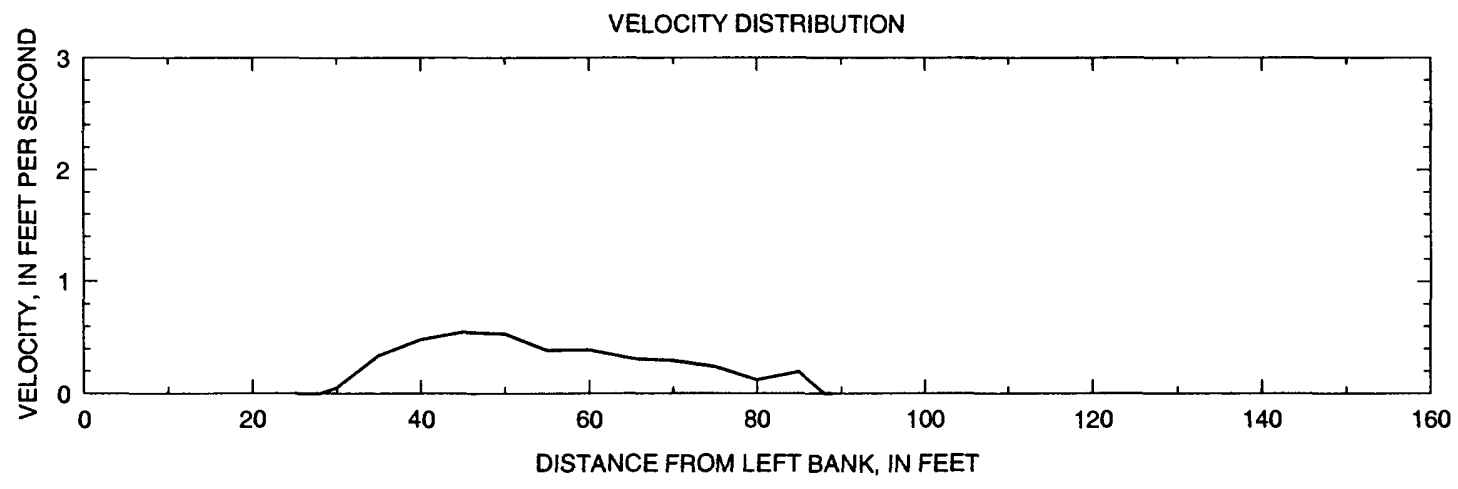

Date of survey, ice conditions, and discharge

- January 12, 1995, 100 percent ice cover Discharge, 42.6 cubic feet per second

Figure D. Continued. 


\section{BRADLEY RIVER BELOW FISH CAMP}

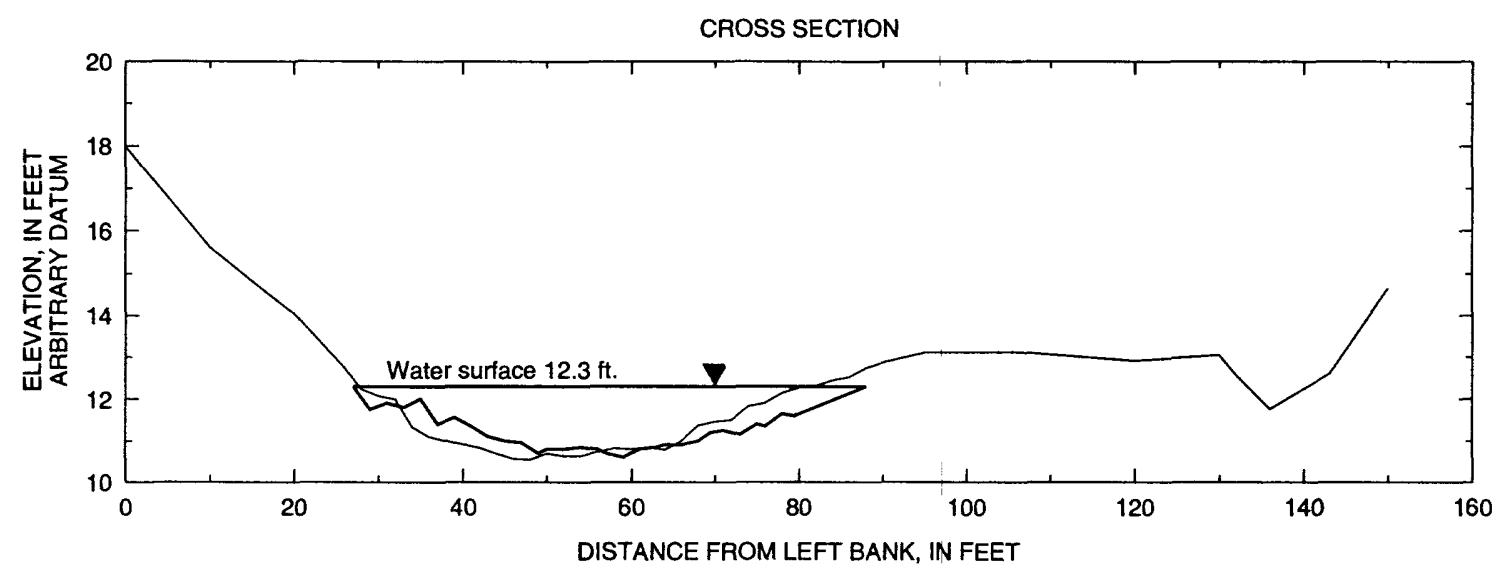

Date of survey, ice conditions, and discharge

__ June 29, 1993, open-water baseline

_- March 1, 1995, 100 percent ice cover Discharge, 47.5 cubic feet per second

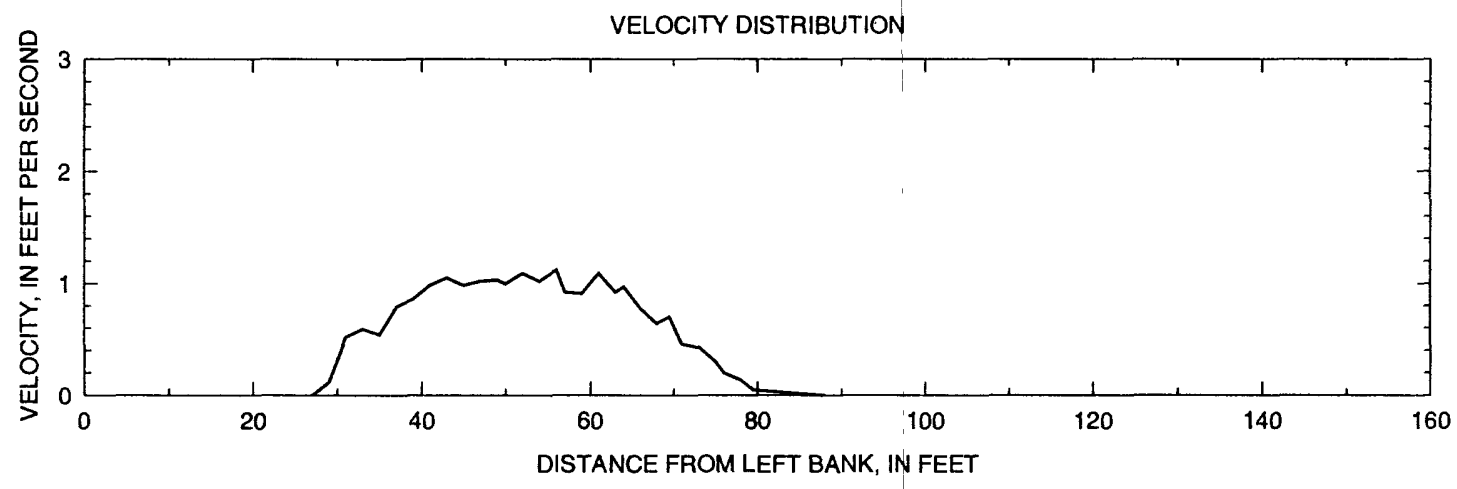

Date of survey, ice conditions, and discharge

_ March 1, 1995, 100 percent ice cover Discharge, 47.5 cubic feet per second

Figure D. Continued. 


\section{BRADLEY RIVER BELOW FISH CAMP}

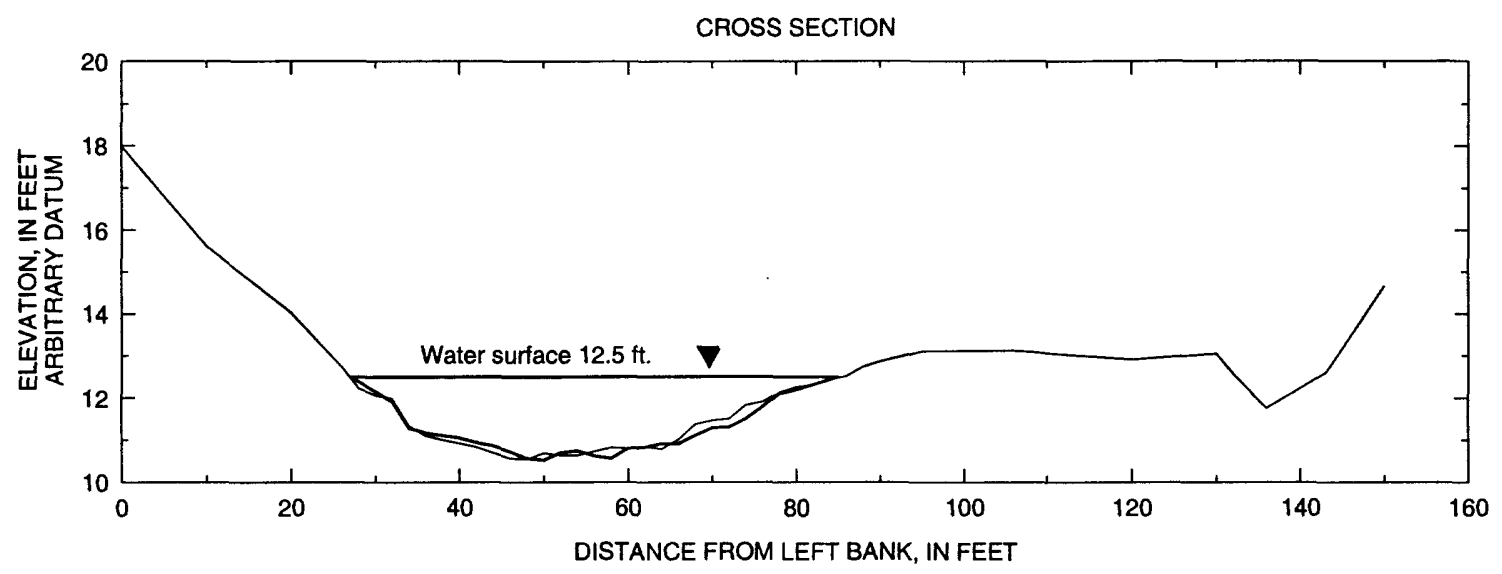

Date of survey, ice conditions, and discharge

_ June 29, 1993, open-water baseline

_ April 5, 1995, minor shore ice

Discharge, 57.9 cubic feet per second

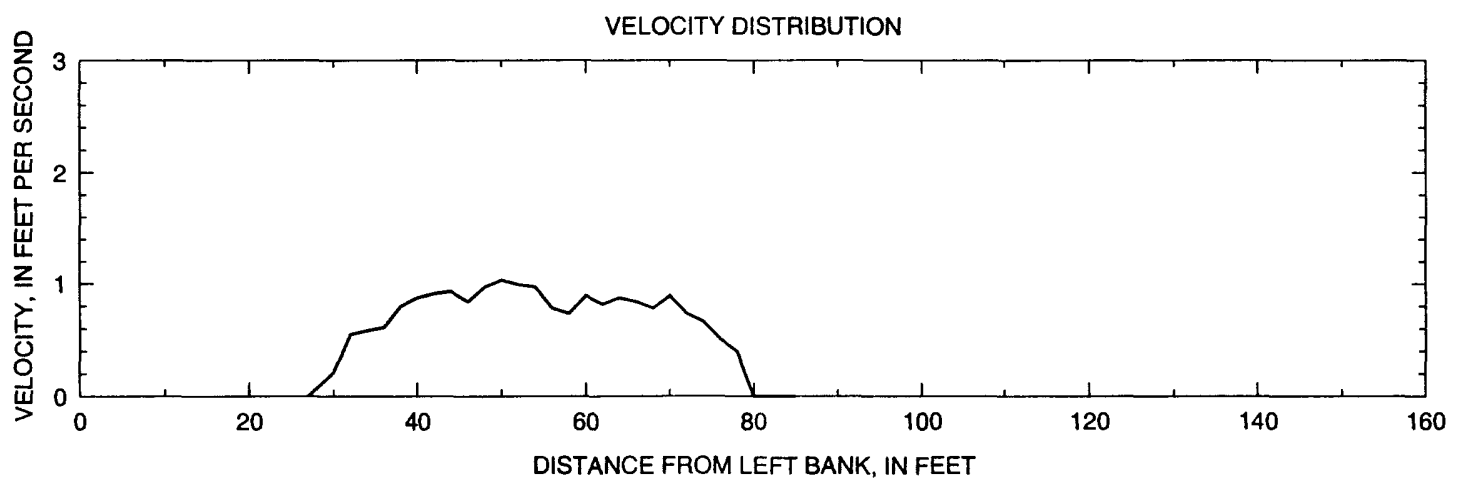

Date of survey, ice conditions, and discharge

April 5, 1995, minor shore ice

Discharge, 57.9 cubic feet per second

Figure D. Continued. 


\section{BRADLEY RIVER AT UPPER RIFFLE REACH}

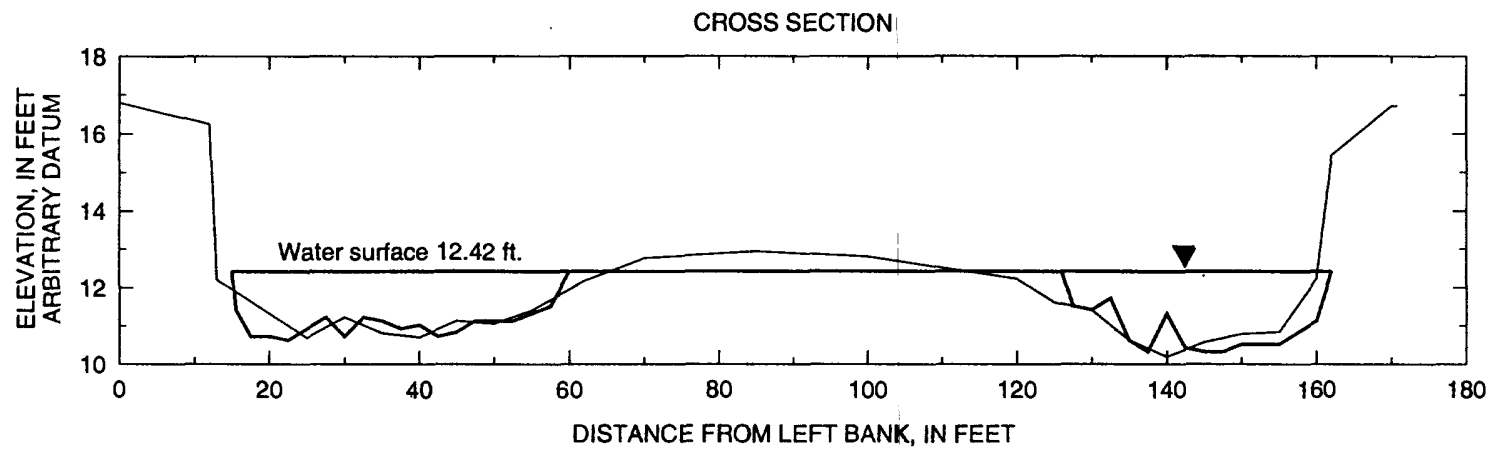

Date of survey, ice conditions, and discharge June 30, 1993, open-water baseline

December 1, 1994, 100 percent ice cover

Discharge, 47.1 cubic feet per second

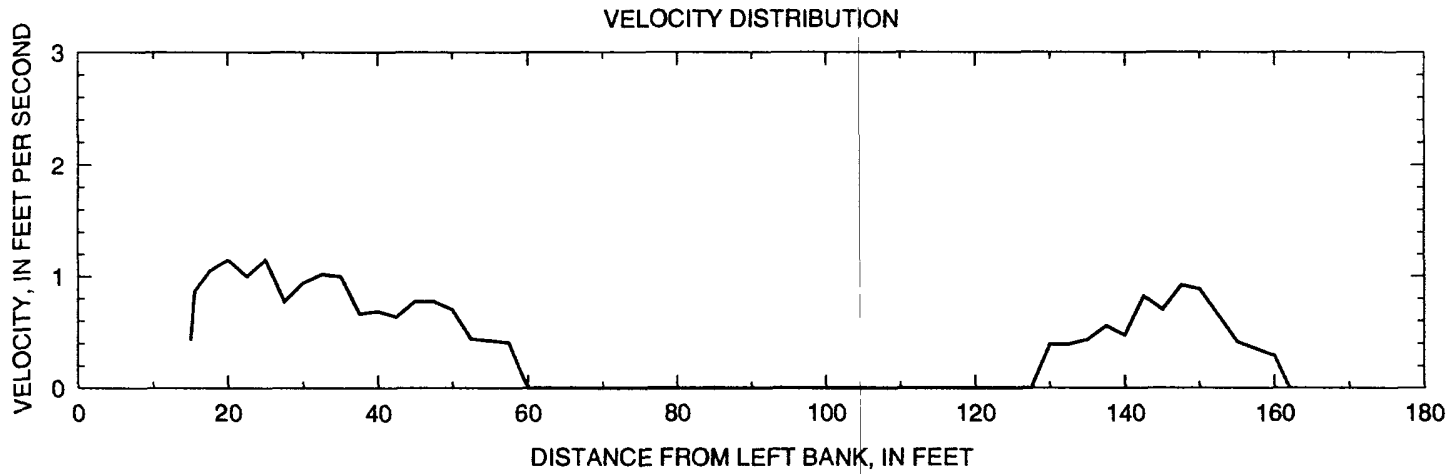

Date of survey, ice conditions, and discharge

- December 1, 1994, 100 percent ice cover Discharge, 47.1 cubic feet per second

Figure E. Cross section and velocity distribution of the lower Bradley River at Upper Riffle Reach (see figure 3 for transect location) 
BRADLEY RIVER AT UPPER RIFFLE REACH

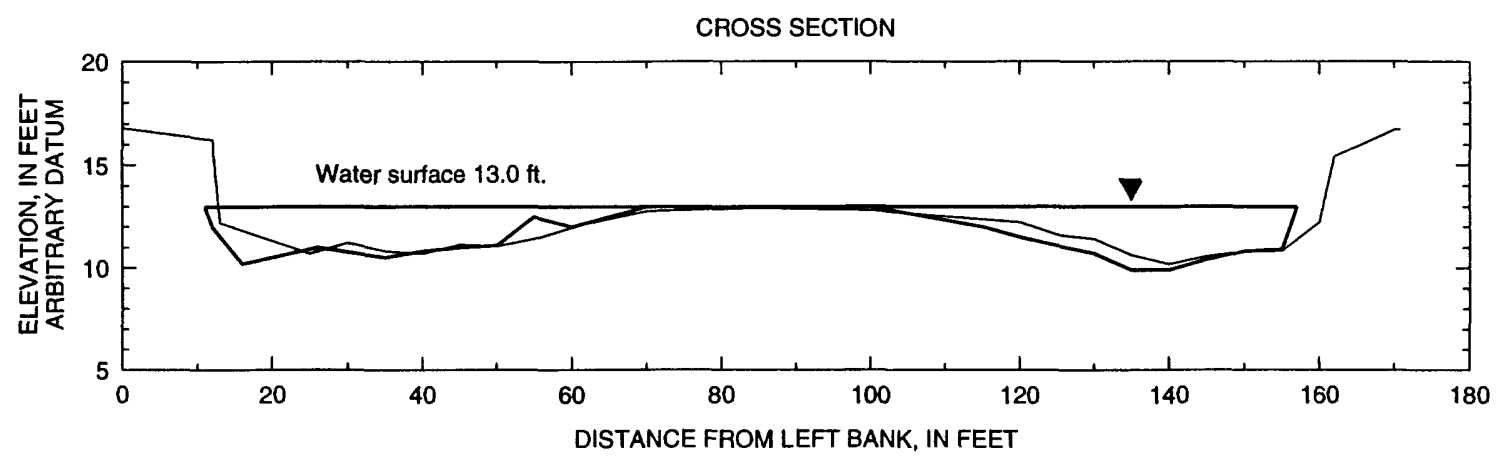

Date of survey, ice conditions, and discharge

__ June 30, 1993, open-water baseline

- January 12, 1995, 100 percent ice cover

Discharge, 50.5 cubic feet per second

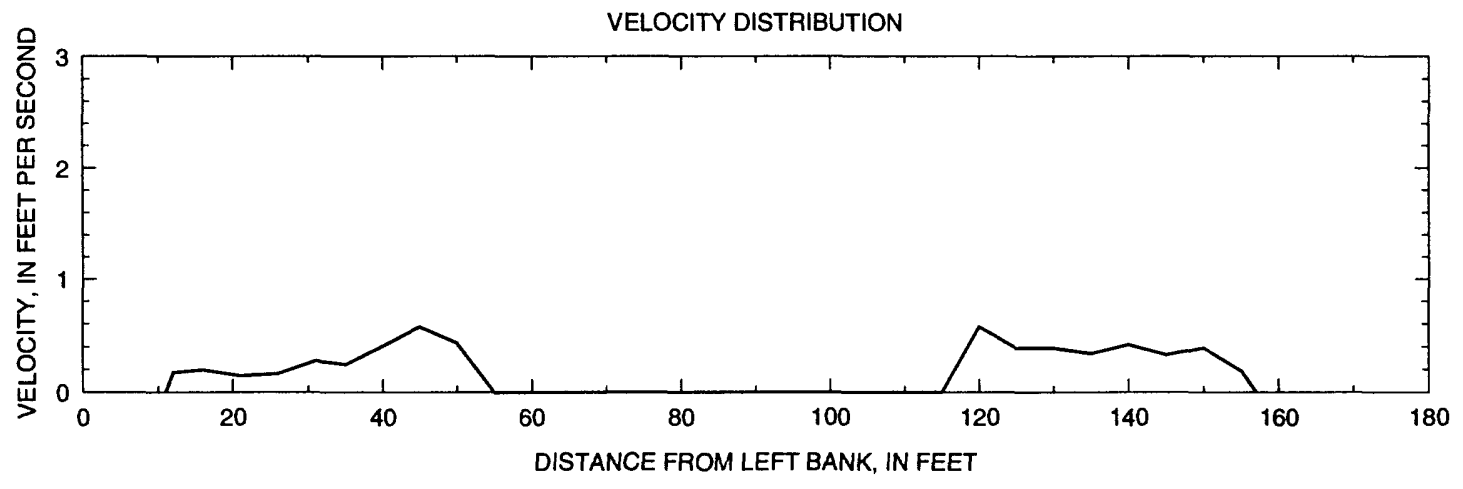

Date of survey, ice conditions, and discharge

January 12, 1995, 100 percent ice cover

Discharge, 50.5 cubic feet per second

Figure E. Continued. 


\section{BRADLEY RIVER AT UPPER RIFFLE REACH}

CROSS SECTION

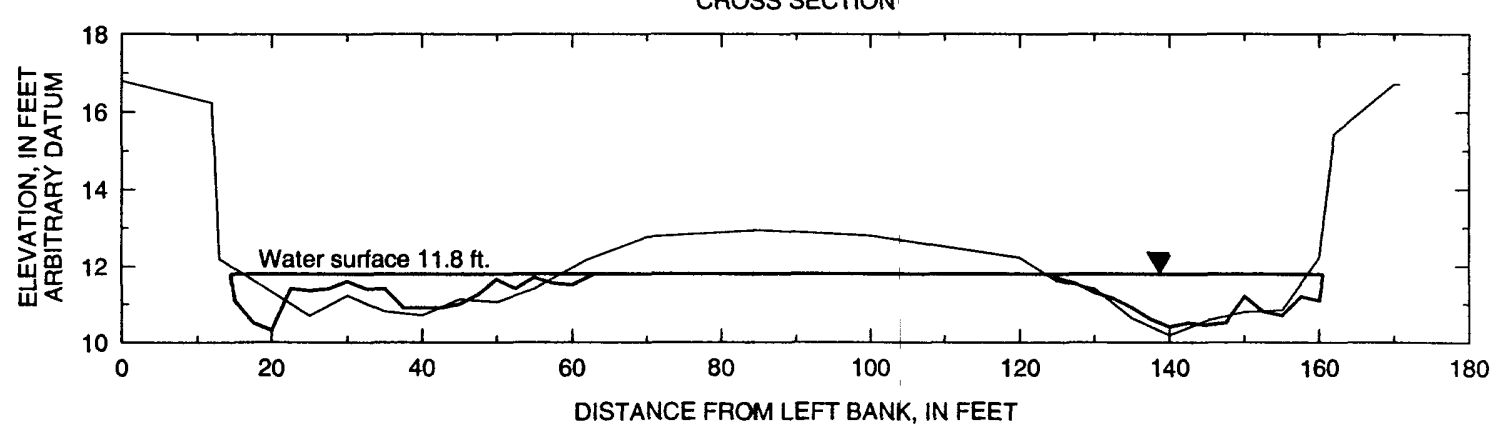

Date of survey, ice conditions, and discharge

+ June 30, 1993, open-water baseline

March 1, 1995, 100 percent ice cover

Discharge, 47.5 cubic feet per second

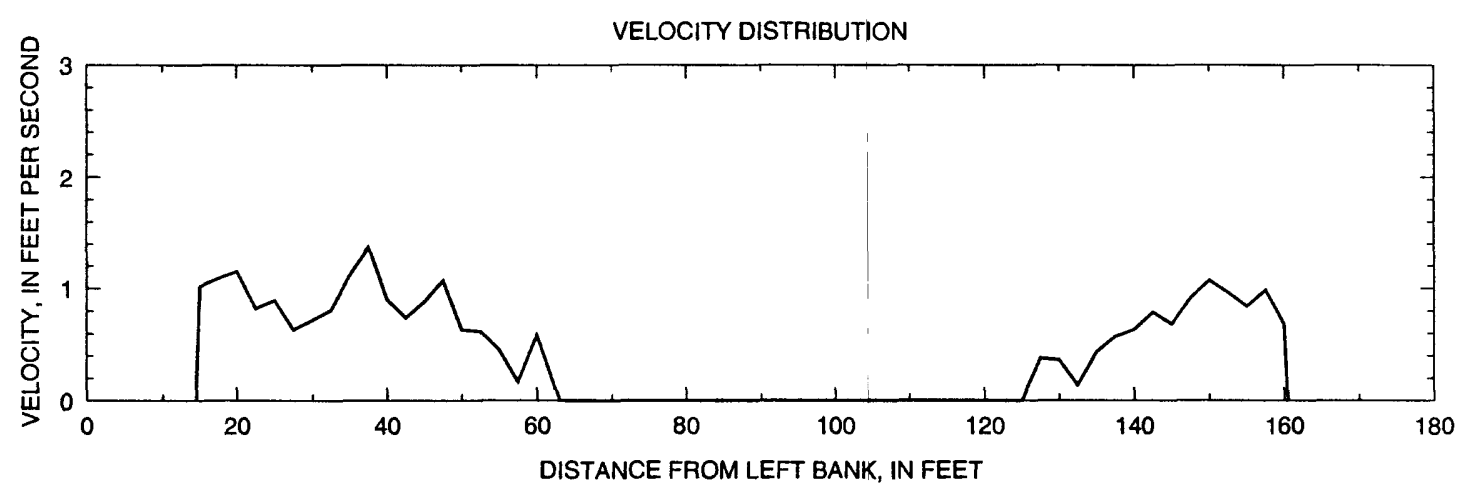

Date of survey, ice conditions, and discharge

March 1, 1995, 100 percent ice cover Discharge, 47.5 cubic feet per second

Figure E. Continued. 
BRADLEY RIVER AT UPPER RIFFLE REACH

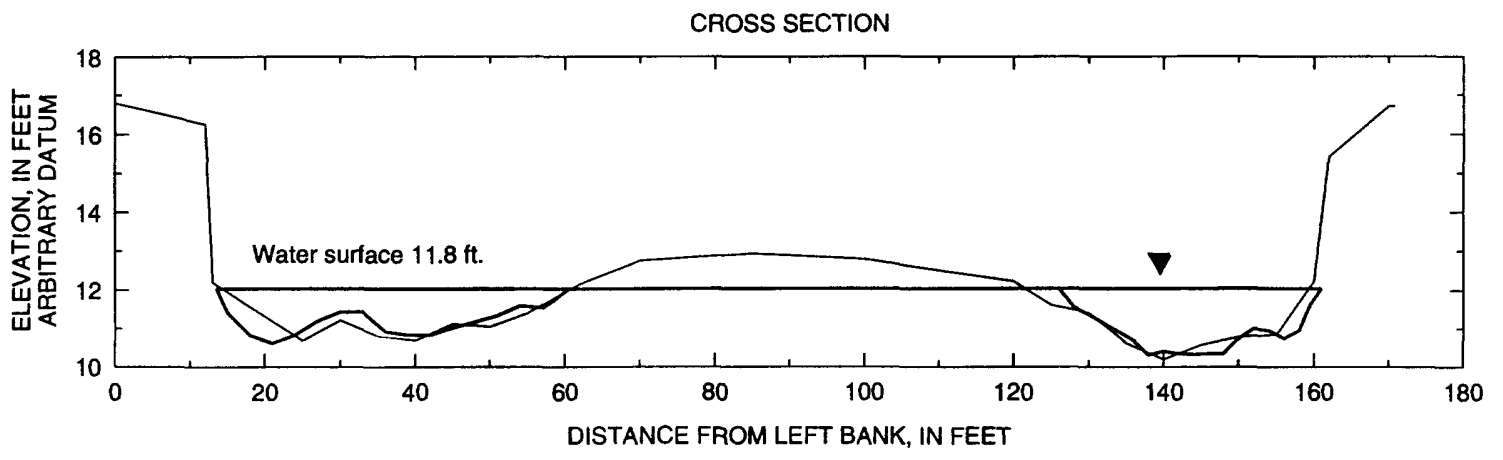

Date of survey, ice conditions, and discharge

__ June 30, 1993, open-water baseline

April 5,1995, some ice debris in left channel Discharge, 56.9 cubic feet per second

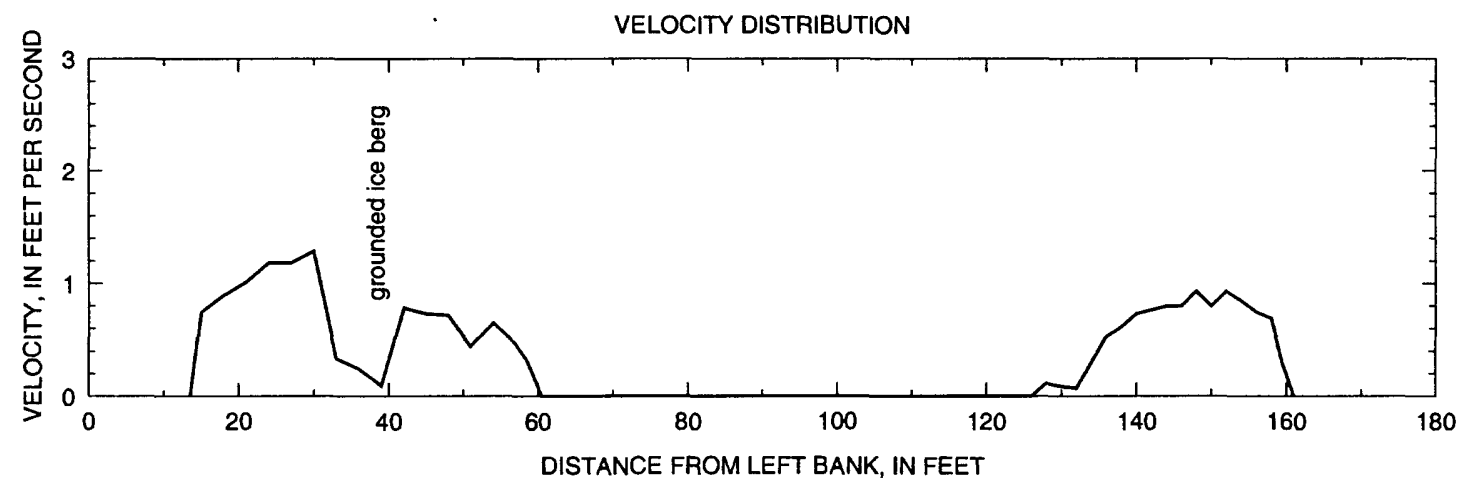

Date of survey, ice conditions, and discharge April 5, 1995, some ice debris in left channel Discharge, 56.9 cubic feet per second

Figure E. Continued. 


\section{BRADLEY RIVER AT LOWER RIFFLE REACH}

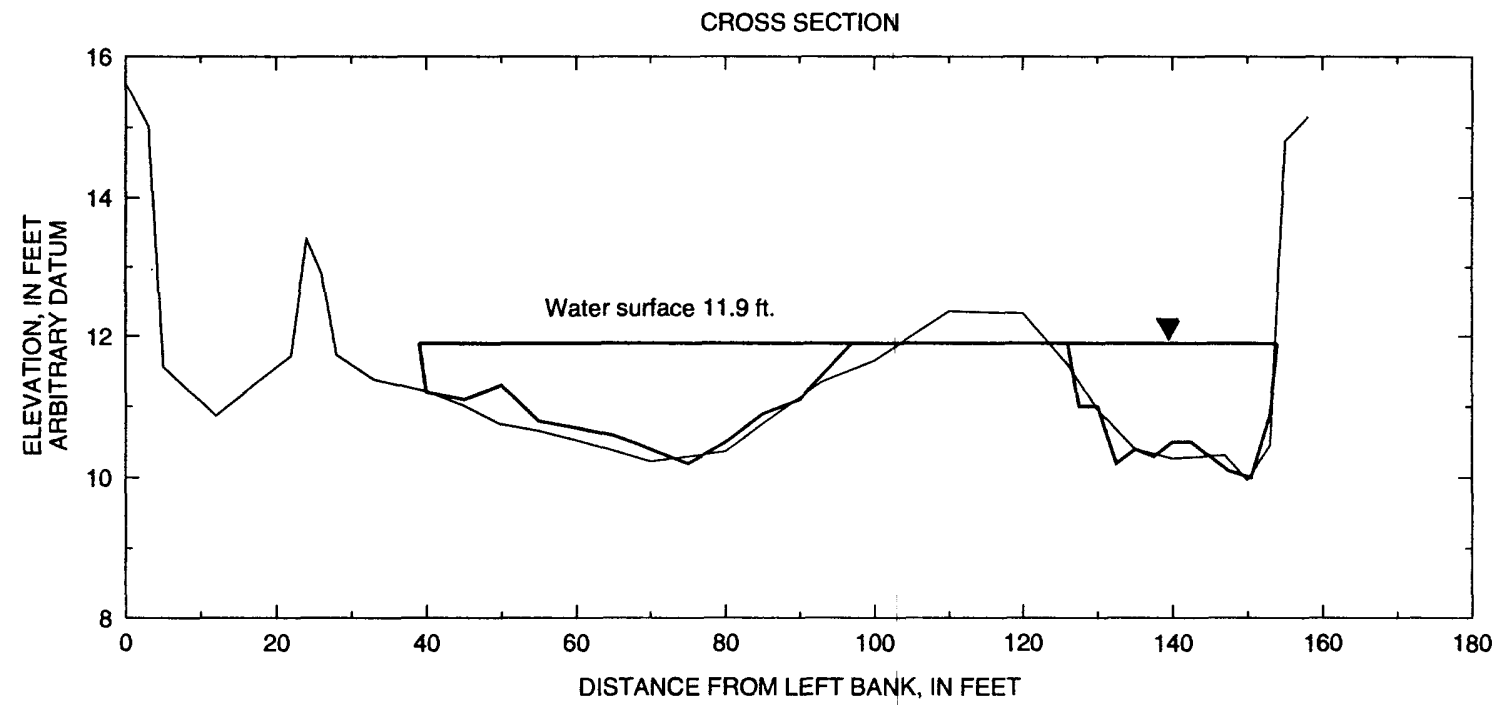

Date of survey, ice conditions, and discharge

_ June 30,1993, open-water baseline

_ November 30, 1994, 100 percent ice cover Discharge, 46.8 cubic feet per second

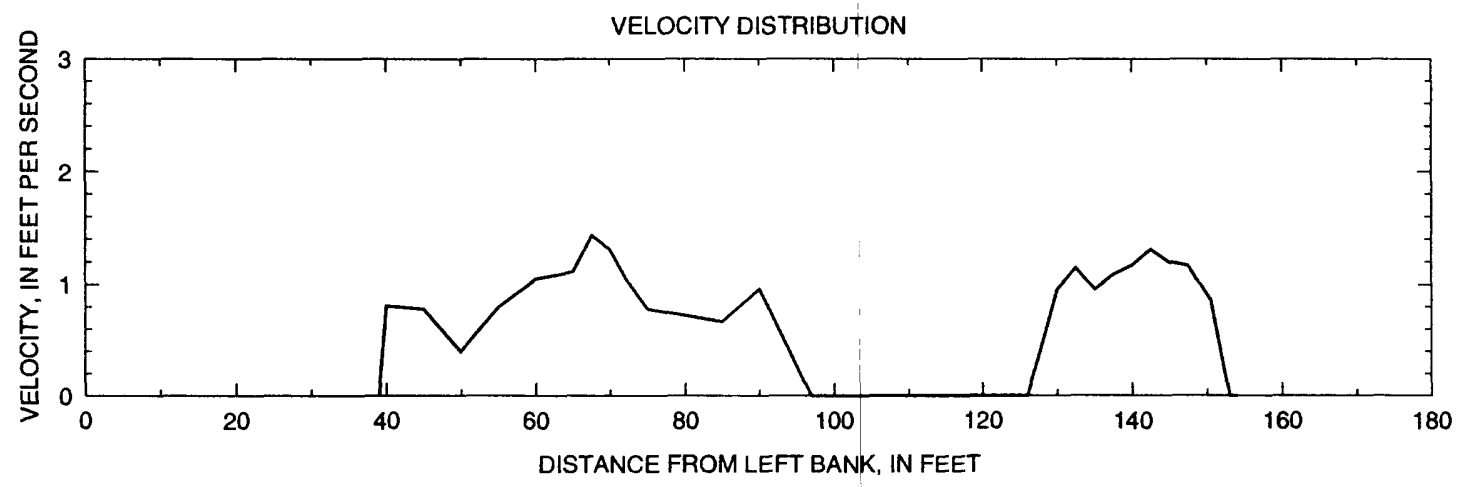

Date of survey, ice conditions, and discharge November 30, 1994, 100 percent ice cover Discharge, 46.8 cubic feet per second

Figure F. Cross section and velocity distribution of the Lower Bradley River at Lower Riffle Reach (see figure 3 for transect location) 


\section{BRADLEY RIVER AT LOWER RIFFLE REACH}

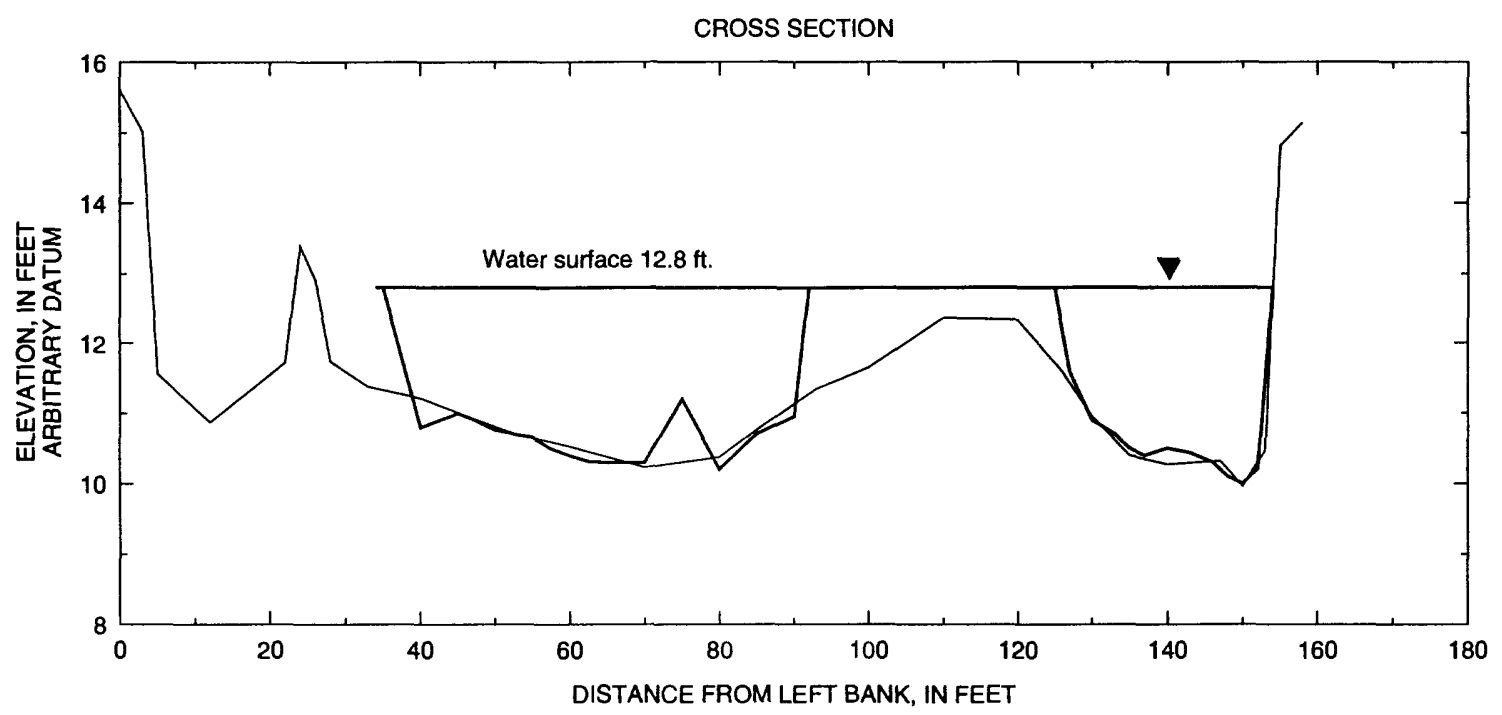

Date of survey, ice conditions, and discharge

__ June 30, 1993, open-water baseline

- January 12, 1995, 100 percent ice cover Discharge, 61.4 cubic feet per second

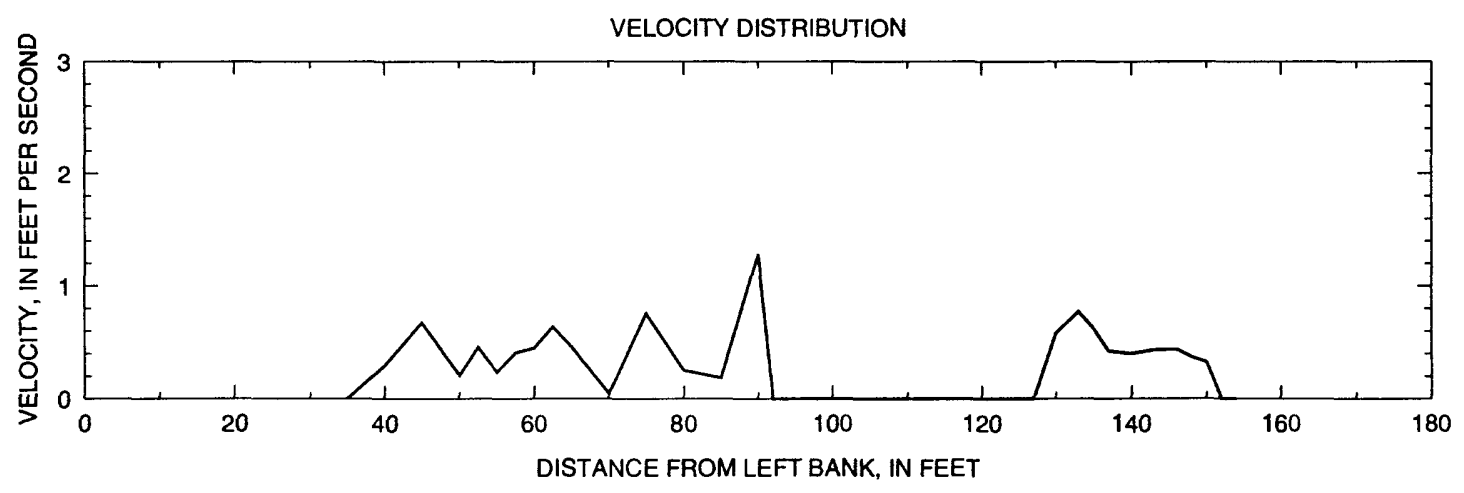

Date of survey, ice conditions, and discharge

January $12,1995,100$ percent ice cover Discharge, 61.4 cubic feet per second

Figure F. Continued. 


\section{BRADLEY RIVER AT LOWER RIFFLE REACH}

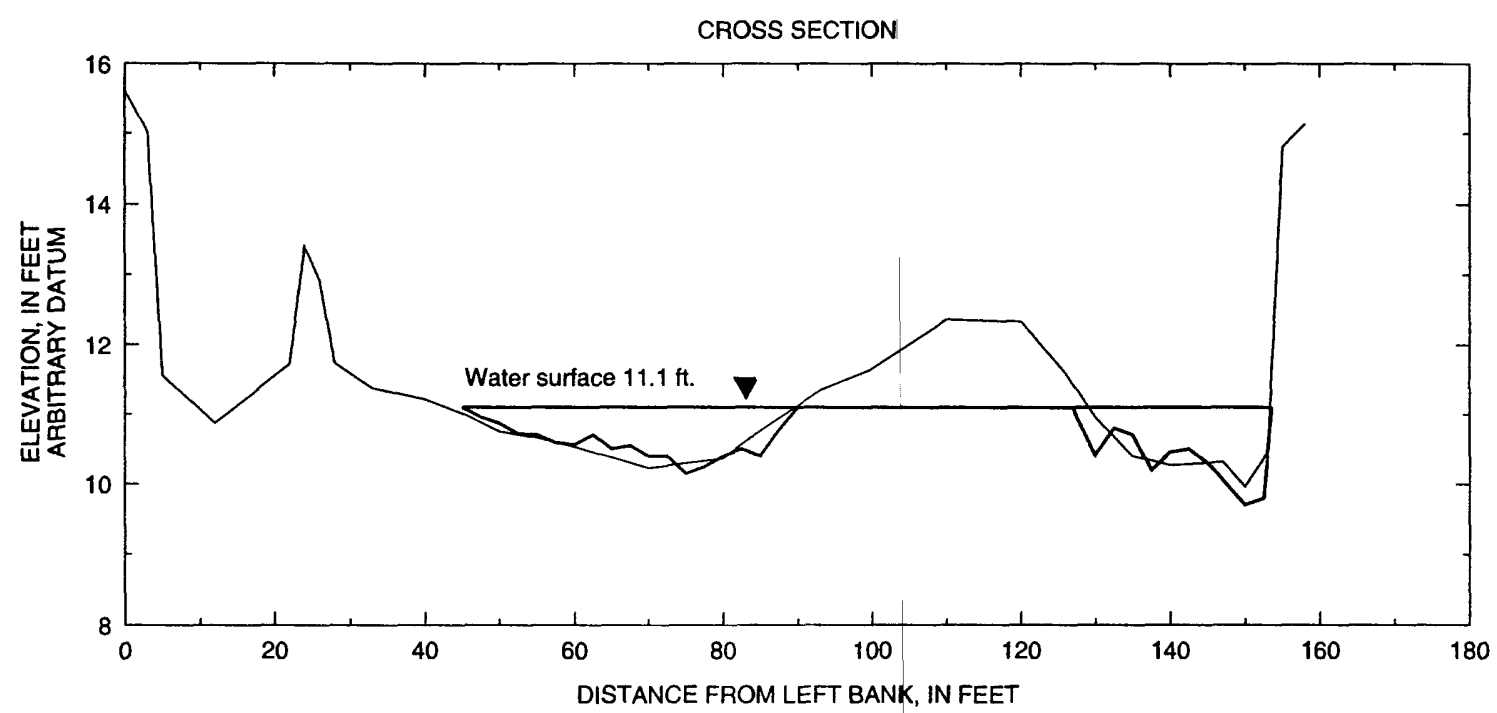

Date of survey, ice conditions, and discharge

__ June 30, 1993, open-water baseline

_ March 1, 1995, 100 percent ice cover Discharge, 47.8 cubic feet per second

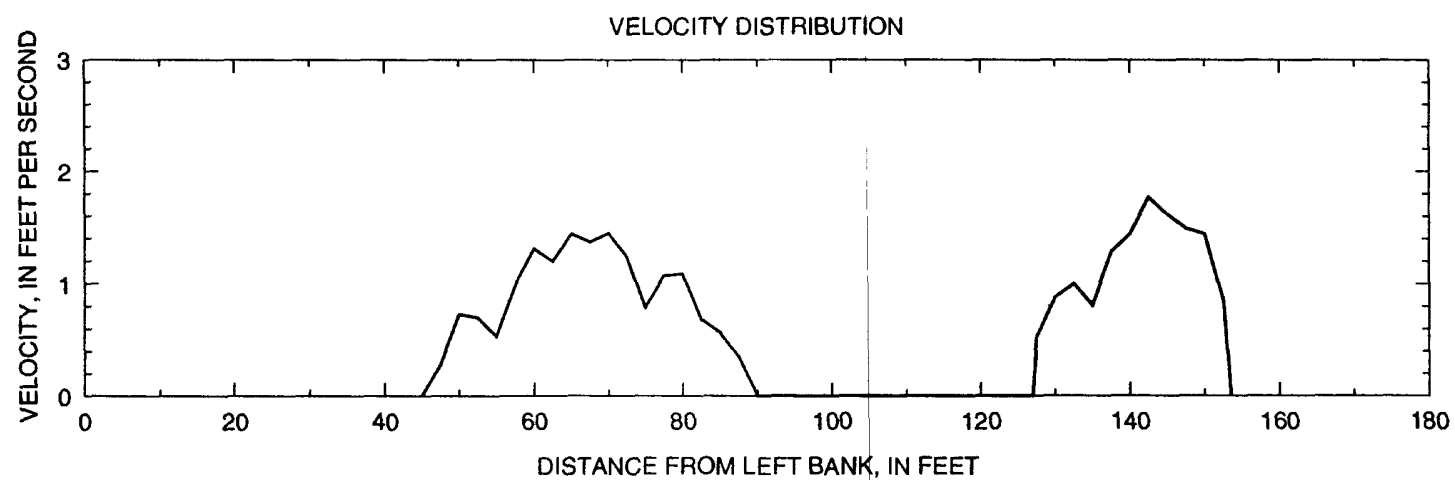

Date of survey, ice conditions, and discharge

\section{March 1, 1995, 100 percent ice cover} Discharge, 47.8 cubic feet per second

Figure F. Continued. 
BRADLEY RIVER AT LOWER RIFFLE REACH

CROSS SECTION

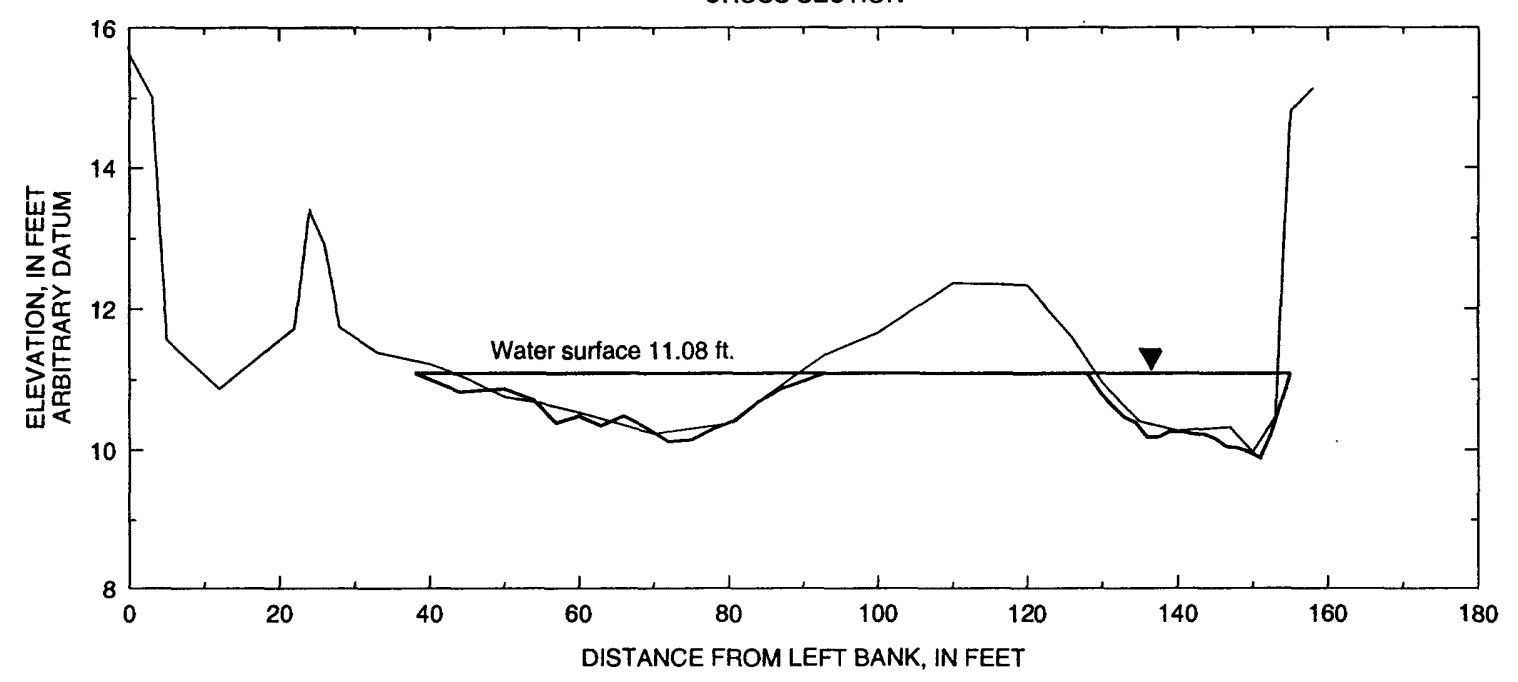

Date of survey, ice conditions, and discharge

_ June 30,1993, open-water baseline

- April 5, 1995, no ice

Discharge, 53.8 cubic feet per second

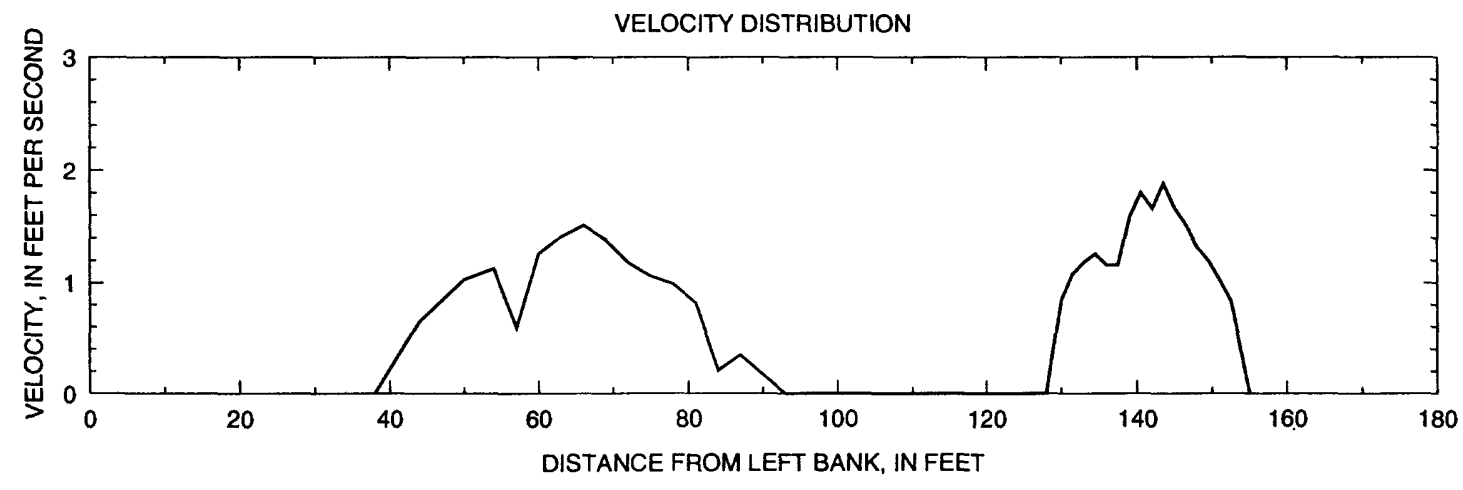

Date of survey, ice conditions, and discharge

April 5, 1995, no ice.

Discharge, 53.8 cubic feet per second

Figure F. Continued. 
A-24 Effect of Ice Formation and Streamflow on Salmon Incubation Habilat in the Lower Bradley River, Alaska 


\section{APPENDIX 2}

Table A1: Selected hydraulic properties for the lower Bradley River, November 1994 to April 1995

Table A2. Selected water-quality data and site characteristics for the lower Bradley River, November 1994 to April 1995 
A-26 Effect of Ice Formation and Streamflow on Salmon Incubation Habitat in the Lower Bradley River, Alaska 
Table A1. Selected hydraulic properties for the lower Bradley River, November 1994 to April 1995.

[ft, foot; $\mathrm{ft}^{2}$, square foot; $\mathrm{ft} / \mathrm{s}$; foot per second; $\mathrm{ft}^{3} / \mathrm{s}$, cubic foot per second; <, less than; >, more than]

\begin{tabular}{|c|c|c|c|c|c|c|c|c|c|c|}
\hline $\begin{array}{l}\text { Transect site } \\
\text { (fig. 3) }\end{array}$ & Date & $\begin{array}{l}\text { Ice } \\
\text { cover } \\
\text { (per- } \\
\text { cent) }\end{array}$ & $\begin{array}{c}\text { Discharge } \\
\left(\mathrm{ft}^{3} / \mathrm{s}\right)\end{array}$ & $\begin{array}{l}\text { Discharge } \\
\text { accuracy } \\
\text { (percent) }\end{array}$ & $\begin{array}{l}\text { Mean } \\
\text { velocity } \\
\text { (ft/s) }\end{array}$ & $\begin{array}{l}\text { Mean } \\
\text { depth } \\
(\mathrm{ft})\end{array}$ & $\begin{array}{l}\text { Top width } \\
\text { (ft) }\end{array}$ & $\begin{array}{c}\text { Area } \\
\left(\mathrm{ft}^{2}\right)\end{array}$ & $\begin{array}{l}\text { Wetted } \\
\text { perimeter } \\
(\mathrm{ft})\end{array}$ & $\begin{array}{l}\text { Hydraulic } \\
\text { radius } \\
\text { (ft) }\end{array}$ \\
\hline \multirow[t]{4}{*}{ Bear Island } & $12-01-94$ & 100 & 45.5 & $>8$ & 0.66 & 0.80 & 93.0 & 74.6 & 93.9 & 0.79 \\
\hline & $01-11-95$ & 80 & 62.7 & 8 & 0.49 & 1.22 & 105 & 129 & 106 & 1.23 \\
\hline & $03-01-95$ & 30 & 53.0 & 8 & 0.98 & 0.67 & 81.0 & 54.3 & 81.3 & 0.70 \\
\hline & $04-05-95$ & $<10$ & 56.7 & 5 & 0.91 & 0.72 & 85.8 & 62.2 & 86.5 & 0.70 \\
\hline \multirow[t]{4}{*}{ Tidewater } & $12-01-94$ & 100 & 55.2 & $>8$ & 0.76 & 1.74 & 41.5 & 72.2 & 43.3 & 1.67 \\
\hline & $01-12-95$ & 90 & (a) & -- & -- & -- & -- & - & -- & -- \\
\hline & 03-01-95 & 100 & 52.5 & 8 & 1.11 & 1.25 & 38.0 & 47.4 & 38.6 & 1.23 \\
\hline & 04-05-95 & 0 & 57.1 & 8 & 1.13 & 1.26 & 40.0 & 50.4 & 40.5 & 1.24 \\
\hline \multirow{4}{*}{$\begin{array}{c}\text { Tree Bar } \\
\text { Reach }\end{array}$} & $11-30-94$ & 100 & 51.8 & $>8$ & 1.19 & 0.93 & 59.0 & 55.0 & 60.1 & 0.92 \\
\hline & $01-12-95$ & 90 & (a) & -- & -- & -- & -- & -. & -- & -- \\
\hline & $02-28-95$ & 100 & 56.5 & 8 & 0.97 & 0.84 & 69.0 & 58.0 & 69.9 & 0.85 \\
\hline & $04-04-95$ & $<10$ & 55.3 & 5 & 1.24 & 0.65 & 69.0 & 44.5 & 69.2 & 0.64 \\
\hline \multirow{4}{*}{$\begin{array}{l}\text { Below Fish } \\
\text { Camp }\end{array}$} & $11-29-94$ & 100 & 48.4 & $>8$ & 0.67 & 1.22 & 59.7 & 72.7 & 60.1 & 1.21 \\
\hline & $01-12-95$ & 100 & 42.6 & $>8$ & 0.34 & 1.95 & 64.0 & 125 & 64.5 & 1.94 \\
\hline & $03-01-95$ & 100 & 47.5 & $b_{>}>8$ & 0.79 & 0.98 & 61.0 & 60.1 & 61.3 & 0.99 \\
\hline & $04-04-95$ & $<10$ & 57.9 & 8 & 0.81 & 1.23 & 58.0 & 71.5 & 58.3 & 1.23 \\
\hline \multirow{4}{*}{$\begin{array}{l}\text { Upper Riffle } \\
\text { Reach }\end{array}$} & $12-01-94$ & 100 & 47.1 & $b_{>}>8$ & 0.72 & 0.79 & 77.6 & 61.4 & 80.3 & 0.76 \\
\hline & $01-12-95$ & 100 & 50.5 & $>8$ & 0.33 & 1.43 & 116 & 166 & 118 & 1.41 \\
\hline & $03-01-95$ & 100 & 47.5 & 8 & 0.81 & 0.69 & 84.5 & 58.3 & 85.9 & 0.69 \\
\hline & $04-05-95$ & $<15$ & 56.9 & 5 & 0.70 & 1.00 & 82.0 & 81.8 & 82.8 & 0.99 \\
\hline \multirow{4}{*}{$\begin{array}{l}\text { Lower Riffle } \\
\quad \text { Reach }\end{array}$} & $11-30-94$ & 100 & 46.8 & $>8$ & 1.00 & 0.55 & 84.0 & 46.9 & 86.4 & 0.55 \\
\hline & $01-12-95$ & 100 & 61.4 & 8 & 0.42 & 1.69 & 86.0 & 145 & 88.7 & 1.63 \\
\hline & $03-01-95$ & 100 & 47.8 & 8 & 1.14 & 0.59 & 71.0 & 42.0 & 72.5 & 0.59 \\
\hline & $04-05-95$ & 0 & 53.8 & 5 & 1.14 & 0.57 & 82.0 & 47.0 & 82.3 & 0.57 \\
\hline
\end{tabular}

${ }^{a}$ Unable to measure all properties because of thin ice and deep water.

${ }^{b}$ Measurements may be tide affected. 
Table A2. Selected water-quality data and site characteristics for the lower Bradley River, November 1994 to April 1995.

[mm Hg, millimeter of mercury; ${ }^{\circ} \mathrm{C}$, degree Celsius; $\mathrm{mg} / \mathrm{L}$, milligram per liter; $\mu \mathrm{S} / \mathrm{cm}$, microsiemen per centimeter;

$\mathrm{ft}$, foot; ft/s, foot per second; --no data]

\begin{tabular}{|c|c|c|c|c|c|c|c|c|c|c|c|}
\hline \multirow[b]{2}{*}{$\begin{array}{c}\text { Transect site } \\
\text { (fig. 3) }\end{array}$} & \multirow[b]{2}{*}{ Date } & \multirow[b]{2}{*}{$\begin{array}{c}\text { Baro- } \\
\text { metric } \\
\text { pressure } \\
(\mathrm{mm} \mathrm{Hg})\end{array}$} & \multicolumn{4}{|c|}{ Surface water } & \multicolumn{3}{|c|}{ Intragravel water } & \multicolumn{2}{|c|}{$\begin{array}{l}\text { Intragravel sample } \\
\text { location }\end{array}$} \\
\hline & & & $\begin{array}{c}\text { Temper- } \\
\text { ature } \\
\left({ }^{\circ} \mathrm{C}\right)\end{array}$ & $\begin{array}{c}\text { Dissolved } \\
\text { oxygen } \\
\text { (mg/L) }\end{array}$ & $\begin{array}{l}\text { Dissolved } \\
\text { oxygen } \\
\text { percent } \\
\text { saturation }\end{array}$ & $\begin{array}{c}\text { Specific } \\
\text { conduct- } \\
\text { ance } \\
(\mu \mathrm{S} / \mathrm{cm})\end{array}$ & $\begin{array}{c}\text { Temper- } \\
\text { ature } \\
\left({ }^{\circ} \mathrm{C}\right)\end{array}$ & $\begin{array}{l}\text { Dissol- } \\
\text { ved } \\
\text { oxygen } \\
\text { (mg/L) }\end{array}$ & $\begin{array}{l}\text { Dissolved } \\
\text { oxygen } \\
\text { percent } \\
\text { saturation }\end{array}$ & $\begin{array}{l}\text { Depth of } \\
\text { water } \\
\text { above } \\
\text { streambed } \\
\text { (ft) }\end{array}$ & $\begin{array}{l}\text { Surface } \\
\text { water } \\
\text { velocity } \\
\text { (ft/s) }\end{array}$ \\
\hline \multirow[t]{4}{*}{ Bear Island } & $12-01-94$ & 775 & 0.0 & 14.8 & 100 & 70 & -- & 13.3 & -- & 0.80 & 0.6 \\
\hline & $01-11-95$ & 759 & 0.0 & 14.4 & 99 & 75 & -- & 12.1 & -- & 0.80 & 0.0 \\
\hline & 03-01-95 & 780 & 0.5 & 14.4 & 98 & 62 & -- & 14.1 & -- & 0.45 & 0.3 \\
\hline & 04-05-95 & 752 & 1.0 & 14.1 & 100 & 64 & -- & 12.4 & -- & 1.10 & 0.6 \\
\hline \multirow[t]{4}{*}{ Tidewater } & $12-01-94$ & 775 & 0.0 & 14.8 & 100 & 69 & -- & 11.4 & - & -- & -- \\
\hline & $01-12-95$ & 762 & 0.0 & 14.3 & 98 & 68 & -- & -- & -. & - & -- \\
\hline & 03-01-95 & 778 & 0.0 & 14.4 & 96 & 62 & -- & 13.0 & -- & 0.4 & 0.2 \\
\hline & 04-05-95 & 754 & 1.0 & 14.0 & 99 & - & -- & 12.4 & -- & 1.6 & 1.0 \\
\hline \multirow{4}{*}{$\begin{array}{l}\text { Tree Bar } \\
\text { Reach }\end{array}$} & $11-30-94$ & 770 & 0.0 & 14.7 & 99 & 74 & 1.0 & 13.4 & 90 & $<1.2$ & -- \\
\hline & $01-12-95$ & 762 & 0.0 & 14.8 & 101 & 69 & -- & -- & -- & -. & -- \\
\hline & 03-01-95 & 780 & 0.0 & 14.4 & 96 & 62 & 1.0 & 13.0 & 87 & - & - \\
\hline & 04-05-95 & 754 & 1.5 & 13.9 & 99 & 63 & 1.5 & 12.5 & 89 & 0.96 & 1.2 \\
\hline \multirow{4}{*}{$\begin{array}{l}\text { Below Fish } \\
\text { Camp }\end{array}$} & $12-01-94$ & 774 & 0.0 & 15.0 & 101 & 70 & -- & 12.8 & -- & 0.4 & 0.6 \\
\hline & $01-12-95$ & 762 & 0.0 & 14.8 & 101 & 69 & -- & -- & -. & - & -- \\
\hline & 03-01-95 & 781 & 0.0 & 14.5 & 97 & 62 & -- & 13.2 & -- & 0.4 & 0.5 \\
\hline & 04-05-95 & 754 & 1.0 & 14.0 & 100 & -- & -- & 12.5 & -- & 1.22 & 0.9 \\
\hline \multirow{4}{*}{$\begin{array}{l}\text { Upper Riffle } \\
\text { Reach }\end{array}$} & $12-01-94$ & 776 & 0.0 & 14.6 & 98 & 70 & -- & 10.7 & -- & 0.80 & 0.4 \\
\hline & $01-12-95$ & 762 & 0.0 & 14.7 & 101 & 71 & -- & 11.4 & -- & 0.70 & 0.2 \\
\hline & 03-01-95 & 782 & 0.0 & 14.2 & 95 & 64 & -- & 13.9 & & 0.65 & 0.1 \\
\hline & 04-05-95 & 752 & 1.0 & 13.0 & 99 & 65 & -- & 12.2 & -- & 1.00 & 0.1 \\
\hline \multirow{4}{*}{$\begin{array}{l}\text { Lower Riffle } \\
\text { Reach }\end{array}$} & $11-30-94$ & 767 & 0.0 & 14.7 & 100 & 76 & -- & 10.1 & -- & 0.90 & 1.2 \\
\hline & $01-12-95$ & 762 & 0.0 & 14.5 & 99 & 71 & -- & 12.5 & -- & 0.80 & $<0.6$ \\
\hline & 03-01-95 & 782 & 0.0 & 14.4 & 96 & 64 & -- & 13.3 & -- & 0.15 & 0.5 \\
\hline & 04-05-95 & 752 & 1.0 & 13.8 & 98 & 64 & -- & 10.8 & -- & $<1.2$ & $<2.0$ \\
\hline
\end{tabular}

